Port-Jackson Heads and the mouth of the Clarence River; and it probably ranges further north.

\title{
DESCRIPTION OF PLATE XXXIV.
}

Figs. 1, 1 a. Helix alfredi, p. 323.

$2,2 a$. millicente, p. 323.

3. Bulimus hargravesi, p. 323.
Fig. 4. Voluta kingi, p. 324.

5. - coniformis, p. 324 .

6. - punctata, p. 324.

May $2,1871$.

The Viscount Walden, President, in the Chair.

Mr. Sclater exhibited the shell of a River-tortoise of the genus Pelomedusa from the Upper Zambesi, and made the following remarks upon it:-

"Mr. E. L. Layard has placed in my hands for examination the shell of a River-tortoise obtained on the Upper Zambesi by Mr. J. Chapman during his well-known expedition, which seems to indicate the existence in that district of a species of Pelomedusa more nearly allied to $P$. gehafie of Eastern Africa than to P. galeata, the common species of the Cape Colony. In P. galeata the two pectoral shields of the thorax unite in the middle line and form a suture which is nearly two-thirds of the length of the suture between the two abdomiual shields. In $P$. gehafie the pectoral shields terminate on their inner sides in angular points, which do not meet together in the middle line, so that the brachial shields join on to the abdominal and entirely divide the pectorals from the middle line. This is shown well in Rüppell's figure (Neue Wirbelth. Amph. t. 1), in a living specimen of P. gehafie in the Society's collection, and in all the examples of this species that $I$ have yet seen. In the present specimen, however, the pectorals come very nearly, if not quite, up to the median line; and there is also some difference in the shape of the other plates, the gulars and intergular being broader and not so deep. Under these circumstances I was inclined to think that the Zambesian Pelomedusa might be referable to a distinct species, especially looking to the very different locality. But Dr. Peters, who has been kind enough to compare the specimen with those of $P$. gehafie in the Berlin Museum, finds amongst the latter one from Sennaar which approximates to the Zambesian example in the pectorals running nearer together, so that I am not willing to found a new species upon a single shell.

"It would be advisable, however, that more examples of the Pelomedusa of the Upper Zambesi should be ohtained, and further comparisons made, as the extension of a species hitherto considered 
326 MR. W. H. HUDSON ON THE BIRDS OY BUENOS AYRES. [May 2,

to be restricted to Abyssinia and Sennaar so far south is certainly a noteworthy although not unprecedented fact.

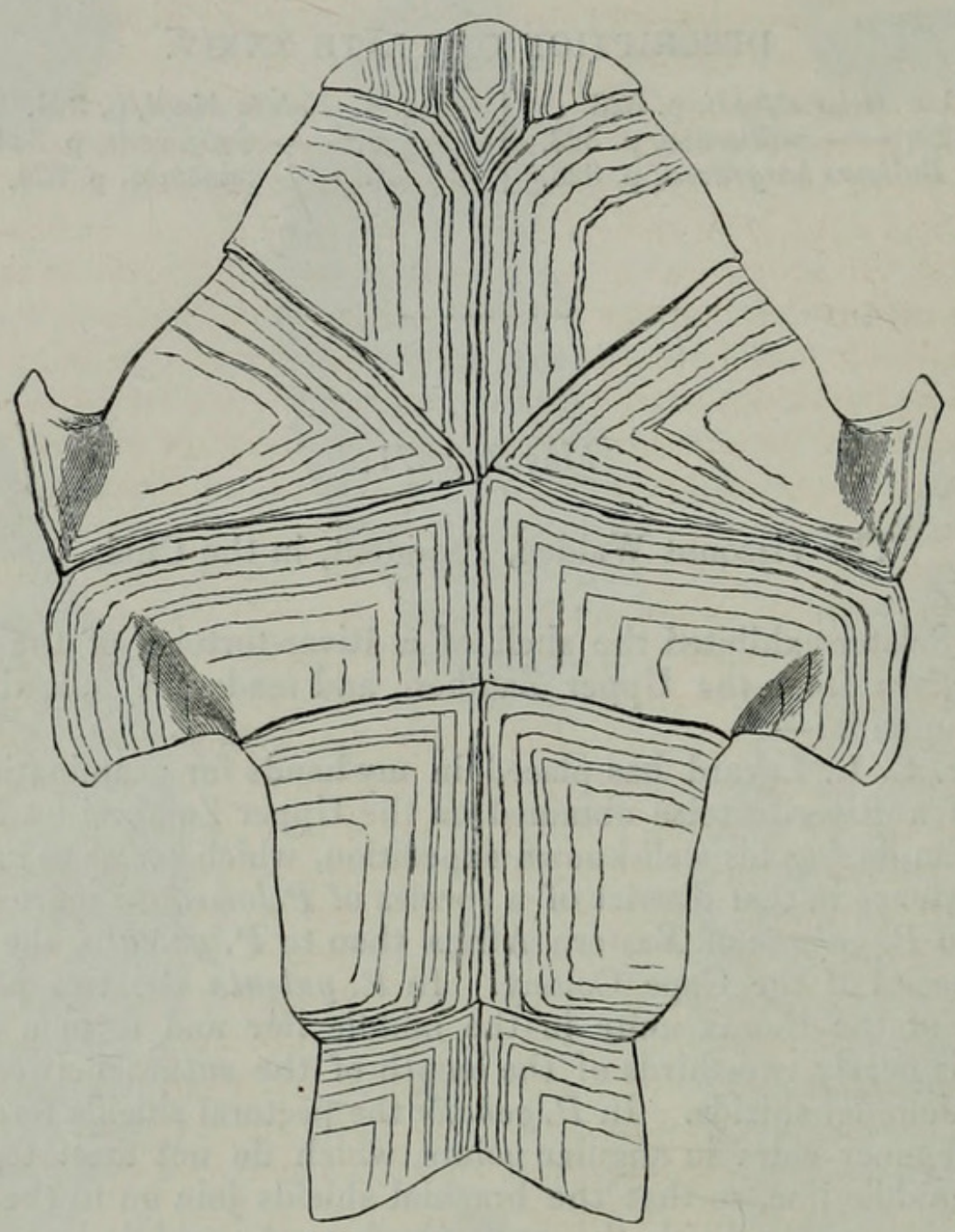

Sternum of Pelomedusa from the Zambesi (nat. size).

"On the Lower Zambesi Dr. Peters found P. galeata, the common species of the Cape Colony (with which $P$. nigra, Gray, of Natal, is, in my opinion, identical*) abundant."

The following (twelfth $\dagger$ ) letter on the ornithology of Buenos Ayres, addressed to the Secretary by Mr. W. H. Hudson, C.M.Z.S., was read:-

"Buenos Ayres, Septemher 22, 1870.

"Dear Sir,-As I have so far always made the species that interested me most at the moment of writing the subject of my letters, I will now say something of the Swallows of this country; for these ever welcome little emigrants are at present hourly arriving and scattering themselves far and wide over the plains of Buenos Ayres.

* See also Strauch, Mém. Ac. St. Pétersb. ser. 7, vol. viii. p. 111.

† See anteà p. 258, for eleventh letter. 
" The Hirundo leucorrhoa is the most common of our Swallows, and in its glossy coat of deep blue and green, with rump and underplumage snowy white, is an elegant and beautiful bird. They are the last of all the migratory species to leave us in autumn, and invariably reappear in small numbers on every warm day in winter, so that some people do not believe that they leave us at all, but only retire to the more sheltered places when the weather is severe. In the winter of 1869 I saw three of them skimming over the plain on one of the coldest days I have ever experienced; the thermometer having stood at $29^{\circ} \mathrm{Fahr}$. the preceding evening. But those that remain through the winter with us are apparently only a few individuals, while in the autumn myriads are seen passing north in their migration, and some years continue passing for upwards of a month. In April 1869, several days after all the Swallows of our five species had totally disappeared, flights of the kind I am describing began again to appear passing north ; and for ten days afterwards they continued to pass. They would descend to sip water from a pool where I watched them, alighting afterwards on the reeds and bushes to rest. Many of them appeared quite tired with their journey, rising reluctantly when approached, and some allowing me to stand within two yards of them without flying. I had never before observed any supplementary or later migration like this; and last autumn (1870) certainly nothing of the kind took place. Probably the migration of this species extends very far south; at present they are passing in great numbers, and have been so passing for the last fifteen days.

"They sometimes build in a tree, in the large nest, previously abandoned, of the Señatero (Anumbius acuticaudatus). I have had occasion before, and shall have it again in descriptions of other species, to mention that interesting bird and its great nest.

"It is, however, under the eaves of houses that these Swallows principally breed; and there is not a house on the pampas, however humble it be, but some of these birds are about it, sportively skimming over and about the roof or curiously peering under the eaves and incessantly uttering their gurgling, happy notes. Indeed their fondness for being close to a house is so remarkably strong that in their longest excursions they are seldom more than five minutes absent from it.

" For a month or six weeks before they begin to build, they seem to be holding an incessant dispute; and however many eligible chinks and holes there may be, the contention is always just as great among them, and is doubtless referable to opposing claims to the best places. The excited twittering, the constant striving of two birds to alight on the same square inch of wall, and the chases they lead each other round and round the house, that always end exactly where they began, tell of clashing interests and great unreasonableness on the part of some among them. By-and-by the quarrel takes a more serious aspect; apparently every argument of which a Swallow is capable has been exhausted, and a compromise more impossible than ever, and so fighting begins. Most vindictively do the little things clutch each 
other, and tumble to the earth twenty times an hour, often struggiing on the ground for a considerable time, and heedless of the screams of alarm their fellows set up above them; for often while they lie struggling do they fall an easy prey to some wily pussy, who thrives on their disputes. When these troubles and feuds are finally ended, they address themselves diligently to their great work, and build a rather large nest. They are not neat or skilful workers, but merely stuff a great quantity of straw and other light material into the hole they build in, and line it thickly with feathers and horsehair. The eggs are white and pointed, from five to seven in number.

"All those species that are liable at any time to become the victims of raptorial birds are much beholden to this Swallow, as he is the most vigilant sentinel they possess : often when the Hawk is still far off and the other birds unsuspicious of his approach, the Swallows suddenly rush up towards the sky with a wild rapid flight, announcing the evil tidings with distracted screams. These are well understood; and the alarm spreads like lightning through the feathered tribes, which are all in terrified commotion, crouching in the grass and plunging into thickets, or mounting upwards to escape by flight. I have often wondered at this ; for surely this swift-winged little bird is the least likely to fall a prey himself.

"They have another habit which cannot but be grateful to the mind of every lover of nature who is an early riser. An hour before sunrise and ere any wild bird has broken the profound silence of night, multitudes of these Swallows, as at the signal of a leader, begin their song, at the same time mounting upwards into the still dusky sky. Their notes at this time are different from the hurried twitterings they utter through the day; they are impressive, and, though soft, may be heard at a long distance; sounding far and near, up in the sky, from so many throats, they have a most charming effect that seems in peculiar harmony with the shadowy morning twilight.

"We often see a Swallow here bearing a general resemblance to the H. leucorrhoa, but larger than that bird, without the blue and green reflections or colouring, and with a tinge of chestnut on the neck, rump, and sides.

"It does not breed or remain any time with us ; but we see so much of it that it should, I think, have its place in our ornithology. I regret to say that $I$ do not know its name or summer-home, not possessing any of those large works on South-American species that could probably enlighten me on the subject*. But even the necessarily imperfect notice I can give of it will perhaps enable you to determine its species. I have scattered through my papers numbers of notes on this Swallow, having observed it much to discover the direction of its flight; but I have always found it very irregular in its movements and times of appearing, also that it is vastly more numerous some years than others. Indeed sometimes a season passes without one individual being seen; other years they have only

* This species may possibly be Petrochelidon americana $(\mathrm{Gm}),.(=$ Hirundo pyrrhonota, Vieill.).-P. L. S. 
appeared very late in autumn. I find the following entries in an old note-book of mine:- 'The first larger white-rumped Swallows I have seen this season appeared to-day (March 18, 1865); but a very few were visible, though the day was sultry and still.' 'They continued to pass every day, observing a north-easterly direction, until the 25th, when a storm came up from the south and cooled the air.'

"But other years they have appeared in spring or early in summer, and, from the south-westerly direction to which they proceed at such times, I am inclined to believe that their summer habitat is in the mountain-region of Western Patagonia. It is remarkable that some years they have continued to pass all, or a greater part of, the hot season, and sometimes appear in vast numbers. Thus in the autumn of $1863 \mathrm{I}$ had a good opportunity of observing them here, as every day thousands of them would descend to the stream near my house to glide over the surface, sip and dip themselves in the water in the manner common to all the Swallows. All the birds that arrived through the hotter part of the day would remain by the stream and congregate by thousands on the bushes; but two or three hours before sunset they would rise up and scatter about the sky and then proceed north or north-east ; this continued for many days ; and they have never since been so numerous.

"They do not, like other birds, when migrating proceed with a rapid flight in a straight line, but are always seen leisurely circling about the sky with a serene graceful flight, never in close flocks, but scattered about here and there-first one bird passing, a minute or so afterwards another, then two or three, and so on for a great part of the day.

"Their notes differ much from those of all our other Swallowsthe birds incessantly uttering, as they circle about on high, a series of remarkable sounds resembling somewhat the creaking of the ungreased axle of a vehicle dragged along at a very slow rate of speed.

" In my next letter I will proceed to describe the other Swallows found in this neighbourhood."

Professor Flower, F.R.S., exhibited, and made remarks on, the mounted skeleton of the young Hippopotamus (Hippopotamus amphibius) recently born in the Society's Gardens, which had been prepared for the collection of the Royal College of Surgeons.

The skin of this specimen, which had been likewise mounted, was stated to have been placed in the Giraffe-house in the Society's Gardens for the examination of visitors.

The Viscount Walden, President of the Society, read a memoir on the birds of the Island of Celebes. Lord Walden commenced his paper with the following observations :-

"Situated in the midst of the vast collection of islands which contribute to form the Malay archipelago, Celebes possesses an avifauna of a type peculiar to itself. The geographical position of the island and the leading characteristics of its fauna have been so clearly 
explained and depicted by Mr. Wallace*, that it is almost unnecessary for me to add any observations of my own on these points.

"This great naturalist has shown that the principal and most striking peculiarity of the fauna of Celebes is its individuality-a generalization fully supported by the evidence furnished by its birds ; and it is the chief object of this paper to give a list of all the birds authentically recorded as inhabitants of Celebes, and to show in some detail the zoogeographical relation of its genera and species.

"Our knowledge of the Celebean ornis has been principally derived from the discoveries of the Dutch travellers Forsten, Von Rosenberg, and Bernstein, and from those of Mr. Wallace. Yet although the Dutch naturalists and our great English traveller ransacked those parts of Celebes they traversed or resided in, they all more or less covered the same ground. The larger portion of the island (fully two-thirds of its area) still remains ornithologically unknown.

"All the species yet described from Celebes appear to have been obtained from the districts of Macassar and Bonthain in the south, and from the districts of Gorontalo and Minahassa in the north. That part of the island which stretches north from about the fifth parallel S. lat. to the Gulf of Tontoli, and west thence to Limbaito, the lesser of the two eastern limbs of the island, the whole of the south-east limb, and all the central country from which these limbs extend seem to have never been explored by an ornithologist.

"The group of islands of which Peling is the largest, and which are only separated from the Sula Islands by the Greyhound Straits, the Togian or Schildpad Islands in the Gulf of Tomini, the islands of Pagasane and of Boton, the island of Saleyer, with its train of smaller satellites almost connecting Celebes with Flores, are nearly wholly unknown. The Sanghir Islands in the north, and the Sula Islands to the east, although as yet only partially investigated, have been shown to possess some species identical with those found in Celebes; consequently they have been regarded by recent authors as forming along with Celebes a separate zoological subarea. But I propose in the following list to include only those species of birds which are known to inhabit the island of Celebes itself. A more definite and more accurate idea of the peculiarities of the Celebean ornis will thus be presented than if genera which occur in the Sula Islands were placed side by side with Celebean genera. If we threw together the ornis of the Sula Islands with that of Celebes we shall find non-Celebean genera (such as Criniger, Ceyx, Platycercus, Pachycephala, and Monarcha) appearing in the list; and the really anomalous character of the Celebean avifauna actually existing on the main island would thereby be apparently greatly modified.

"Mr. Wallace (op. cit. i. p. 425) has estimated the number of known Celebean species of birds at one hundred and ninety-one. I have only been able to add two more to that number; yet there are doubtless many more species represented by Celebean examples in the museums of Europe. On the other hand, many species have * Malay Archipelago, i. chap. xviii. 
been described as possessing a Celebean origin which most assuredly do not occur in the island.

"To give a clear idea of the geographical relation of the Celebean avifauna $I$ have thrown its one hundred and forty-nine genera into tables, and classed them according to the regions and subregions they may be said to belong to. The geographical character of a genus has been determined according to the area which possesses the preponderating number of species. Thus Artamus is classed as an Australian genus, because at least thirteen species of it occur within the Australian region, while one only is peculiar to the Indian; Arachnothera as an Indian genus, although one species is found in New Guinea.

" By means of these tables it will be seen that thirty-eight Indian genera occur in Celebes; of these, three are peculiarly Indo-Malayan.

"TABLE I.-Showing the Indian genera found in Celebes.N.B. Those peculiar to the Indo-Malayan subregion are marked with an asterisk.

1. Poliornis.

2. Spilornis.

3. Polioaëtus.

4. Limnaëtus.

5. Neopus.

6. Lophospiza.

7. Hierax.

8. Ephialtes.

9. Loriculus.

10. Yungipicus.

11. Mulleripicus.

12. Phønicophaus.

*13. Centrococcyx.
14. Craniorrhinus.

15. Lyncornis.

16. Pelargopsis.

17. Callialcyon.

18. Geocichla.

19. Broderipus.

20. Trichostoma.

21. Cyornis.

22. Myiolestes.

23. Hypothymis.

24. Athopyga.

25. Nectarophila. *26. Anthreptes.
27. Arachnechthra.

28. Dicaum.

29. Arachnothera.

*30. Prionochilus.

31. Munia.

*32. Padda.

33. Acridotheres.

34. Sturnia.

35. Osmotreron.

36. Gallus.

37. Erythra.

38. Rallina.

"The next table consists of the twenty-three Australian genera which are also Celebean. Two of these appear to be peculiar to the Australian subregion $\ddagger$; of the remainder some are Papuan, and some extend into the Polynesian subregion.

"T TABLE II.-Showing the Australian genera found in Celebes.N.B. Those belonging especially to the Australian subregion are marked with a dagger $(\dagger)$; to the Papuan $\S$ with an asterisk (*).

*1. Teraspiza.

*2. Erythrospiza.

3. Cacatua.

*4. Tanygnathus.

5. Trichoglossus.

6. Sauropatis.

7. Collocalia.

+8. Scythrops.
*9. Dicrurus.

10. Artamus.

11. Graucalus.

12. Lalage.

*13. Chalcostetha.

*14. Zonøenas.

*15. Turacœena.

*16. Calcenas.
17. Phlegonas.

*18. Myristicivora.

*19. Lamprotreron.

*20. Iotreron.

*21. Leucotreron.

22. Megapodius.

†23. Hydralector.

\footnotetext{
$\ddagger$ Conf. Sclater, P. Z. S. 1869, p. 125.

$\S$ The Papuan Dicruri are generically separable.
} 
" Eighteen Celebean genera may be considered common to the Indian and Australian regions, the proportion of species in each region being about equal. Some occur outside the limits.

“T TABE III.-Showing the genera found in Celebes which are also common to the Indian and Australian regions.-N.B. Genera which do not occur in the Polynesian subregion are marked with an asterisk.

*Tachyspiza.

* Haliastur.

*Cuncuma.

*Baza.

*Eudynamis. Cacomantis.
*Macropteryx.

*Hirundinapus.

*Pitta.

*Volvocivora.

*Calornis.

*Ducula.
*Macropygia.

*Chalcophaps.

* Geopelia.

*Muscadivora.

*Excalfactoria.

*Esacus.

"Fifty-eight are genera which are found within the limits of the Indian region and also beyond. Eight of these belong to the Rapaces, six to the Picaria, two to the Gallina, twenty-five to the Gralla, ten to the Anseres, and only seven to the Passeres. Nine of these fiftyeight genera are unrepresented in the Australian subregion.

"TABLE IV.-Showing the genera represented in Celebes which likewise occur both within and beyond the limits of the Indian region.-N.B. Genera not occurring in the Australian subregion are marked with an asterisk.

Tinnunculus.

*Hypotriorchis.

*Pernis.

Milvus.

Elanus.

Circus.

Athene.

Strix.

Hirundo.

Merops.

* Coracias.

Eurystomus.

*Alcedo.

* Buceros. Acrocephalus.

Cisticola.

* Budytes.

* Pratincola.

* Monticola.

Zosterops.
Corvus.

*Turtur.

Turnix.

Eudromias.

Agialites.

Charadrius.

Strepsilas.

Himantopus.

Porphyrio.

Hypotanidia.

Rallina.

Gallinula.

Numenius.

Actitis.

Lobipes.

Totanus.

Limosa.

Tringa.

Gallinago.
Melanopelargus.

Falcinellus.

Ardea.

Herodias.

Ardetta.

Demiegretta.

Ardeola.

Nycticorax.

Butorides.

*Querquedula.

Mareca.

Dendrocygna.

Hydrochelidon.

Onychoprion.

Pelecanopus.

Plotus.

Phalacrocorax.

Dysporus.

Podiceps. lebes :-

"The following nine genera are peculiar to the island of Ce-

Meropogon.

Monachalcyon.

Ceycopsis.
Artamides.

Gazzola.

Strepticitta.
Enodes.

Scissirostrum.

Megacephalon. 
One genus is restricted to Celebes and the Sanghir islands,

\section{Cittura ;}

one to Celebes and the Philippines,

$$
\text { Prioniturus ; }
$$

and one to Celebes and Ceram,

\section{Basilornis.}

"Of these twelve genera, Meropogon, Strepticitta, and Basilornis belong to the non-Australian families; Gazzola to the almost uni. versal Corvina ; Monachalcyon, Ceycopsis, and Cittura are isolated genera of a family in which the Australian region is pre-eminently rich; Enodes and Scissirostrum have affinities with genera common to the Indian and Australian regions; Megacephalon is strictly Australian. The affinities of Prioniturus seem to be with Australian genera.

"The total number of Celebean genera also found within the Indian region, but not in the Australian, is forty-eight*.

"The total number of Celebean genera also occurring in the Australian region, but not in the Indian, is twenty-three. If we compare these numbers, we find that Celebes contains twenty-five more Indian than Australian genera.

"If we make the same comparison by orders, the following results are obtained:-

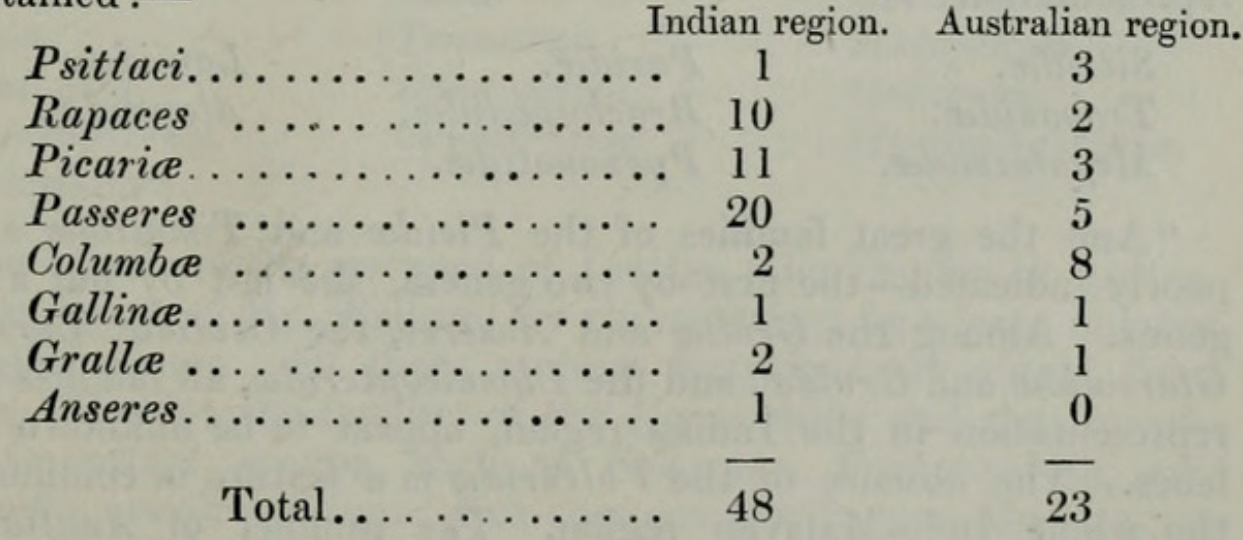

"So while the Celebean Rapaces and Passeres contain a large majority of Indian genera, in the Psittaci and Columba Australian genera preponderate. Loriculus is classed as an Indian genus; yet until the zoogeographical positions of the Philippines and of Celebes are determined the zoogeographical characters of Loriculus cannot be established. Within the limits of the Philippine and Celebean areas, seven out of the thirteen known species occur. Another, $L$. amabilis, a representative form of the Celebean L. stigmatus, occurs in the Sanghir Islands, and is also Papuan, being found at Gilolo and Batchian. The remaining five, one of which (L. flosculus) is the Flores representative of the Javan $L$. pusillus, are peculiar to the Indian region. If, then, we cease to regard Loriculus as having an Indian

* It is true that Buceros, Alcedo, Budytes, and Pratincola occur in some of the Papuan and Moluccan islands; but they cannot be considered as genera belonging to the Australian region. 
origin, all the five genera of Psittaci known in Celebes are either Australian or peculiar. The Columba while imparting a decided, it may even be affirmed an absolute, Australian character to the Celebean avifauna, as clearly indicate a very close Philippine affinity.

"Among the Gallince, Gallus and Megapodius are severally representatives of equally important typical families, characterizing one the Indian, the other the Australian region. But Celebes and the Philippines* are the only areas where representatives of the Phasianidee and Megapodida are associated.

"Among the Picaria, the presence of Scythrops can hardly be deemed sufficient to balance the two genera of Picida, more especially if Scythrops be migratory in Celebes, as in Australia. But though three of the genera belonging to the Alcedinida are Indian, yet the great richness of the family in Celebes forms an important element in favour of the Australian nature of the Celebean ornis.

"But to obtain a still more complete conception of the zoogeographical characters of Celebean ornithology, the following tables have been prepared, showing the principal Indian and Australian genera that do not occur in the island.

"Notwithstanding the great preponderance of Indian genera, some entire families, and a large number of genera characteristic of, if not altogether peculiar to, the Indian regions are wanting in $\mathrm{Ce}-$ lebes. For instance, the following important families are without representation :-

$\begin{array}{lll}\text { Sittida. } & \text { Parida. } & \text { Laniida. } \\ \text { Trogonida. } & \text { Brachypodida. } & \text { Alaudida. } \\ \text { Megalaimida. } & \text { Pycnonotida. } & \end{array}$

"And the great families of the Picida and Timaliida are but poorly indicated-the first by two genera, the last by but a single genus. Among the Gralla and Anseres, the Otidida, Cursorida, Glareolide and Gruide, and the Phonicopteride, all families having representation in the Indian region, appear to be unknown in Celebes. The absence of the Vulturida is a feature in common with the whole Indo-Malayan region. The number of Anatidce and Larida recorded from Celebes is so small that it seems probable that members of those families have been overlooked by collectors.

"After excluding from the list of genera found in the Indian region all those that do not likewise form an Indo-Malayan habitat, at least eighty-eight Indian geuera are absent from Celebes; of these twelve are purely Indo-Malayan.

“ $\mathrm{T}_{\mathrm{ABL}} \mathrm{E}$ V.-Showing the principal Indian genera which are wanting in Celebes.-N.B. Purely Indo-Malayan genera are marked with a dagger.
Ierax.
Bulaca. Ketupa. Phodilus.
Batrachostomus. †Eurylaimus.

* It is as yet uncertain whether the Philippine Gallus inhabits the same islands as the Philippine Megapodii. Gallus is only known for certain to occur in Luzon. 


\begin{tabular}{|c|c|c|}
\hline $\begin{array}{l}\text { Psarisomus. } \\
\text { †Corydon. } \\
\text { +Cymbirhynchus. } \\
\text { +Calyptomena. } \\
\text { Harpactes. } \\
\text { Ceyx. } \\
\text { Nyctiornis. } \\
\text { Chalcococcyx. } \\
\text { Dendrophila. } \\
\text { Chalcoparia. } \\
\text { Orthotomus. } \\
\text { Prinia. } \\
\text { Enicurus. } \\
\text { Corydalla. } \\
\text { Copsychus. } \\
\text { Cittocincla. } \\
\text { Phyllornis. } \\
\text { Iora. } \\
\text { Hypsipetes. } \\
\text { Ixos. } \\
\text { Brachypodius. } \\
\text { Pycnonotus. } \\
\text { Iole. } \\
\text { Criniger. } \\
\text { Irena. } \\
\text { Analcipus. } \\
\text { Brachypteryx. } \\
\text { Myiophonus. }\end{array}$ & $\begin{array}{l}\text { Mixornis. } \\
\text { Malacopteron. } \\
\text { †Macronyx. } \\
\text { Alcippe. } \\
\text { Timalia. } \\
\text { Megalurus. } \\
\text { Garrulax. } \\
\text { Pomatorhinus. } \\
\text { Pteruthrius. } \\
\text { Parus. } \\
\text { †Platylophus. } \\
\text { Lanius. } \\
\text { Tephrodornis. } \\
\text { Buchanga. } \\
\text { Dissemurus. } \\
\text { Chaptia. } \\
\text { Bhringa. } \\
\text { Pericrocotus. } \\
\text { Hemipus. } \\
\text { Eumyias. } \\
\text { †Philentoma. } \\
\text { Tchitrea. } \\
\text { Leucocirca. } \\
\text { Cissa. } \\
\text { †Temnurus. } \\
\text { Dendrocitta. } \\
\text { Crypsirhina. }\end{array}$ & $\begin{array}{l}\text { Eulabes. } \\
\text { Ploceus. } \\
\text { Passer. } \\
\text { Mirafra. } \\
\text { Palcornis. } \\
\text { Megalaima. } \\
\text { Xantholama. } \\
\text { Meiglyptes. } \\
\text { Hemicircus. } \\
\text { Micropternus. } \\
\text { Chrysocolaptes. } \\
\text { Chrysophlegma. } \\
\text { Tiga. } \\
\text { Sasia. } \\
\text { Rhopodytes. } \\
\text { Coccystes. } \\
\text { †Peloperdix. } \\
\text { Arborophila. } \\
\text { Perdicula. } \\
\text { Pavo. } \\
\text { †Argusianus. } \\
\text { Polyplectron. } \\
\text { Euplocamus. } \\
\text { †Rollulus. } \\
\text { Metopidius. } \\
\text { Gallicrex. } \\
\text { Hydrophasianus }\end{array}$ \\
\hline
\end{tabular}

"The islands to the eastward of Celebes (the Papuan or AustroMalayan region of $\mathrm{Mr}$. Wallace) are characterized by a large number of peculiar genera. Of these at least forty-four are absent from Celebes. Besides the families of the Epimachida and the Paradiseida, important groups, such as Podargus, Pachycephala, and Manucodia, are all wanting. Nor does a single Papuan Muscicapine form occur in Celebes. Papuan genera belonging to the two great orders Psittaci and Columba, orders which are so largely developed in the Australian region, and in no part of that region to a greater extent than in its Papuan subregion, are found in Celebes. This fact is justly regarded as sufficient to stamp the ornis of that island with a Papuan character. Yet among the Psittacida such essentially typical Australian genera (also Papuan) as Lorius and Platycercus do not extend to Celebes. And several peculiar Papuan types are there unknown. The Columbæ of the Papuan subregion are well represented in Celebes; yet, with one exception (Phlegoenas), all the Papuan genera of the Gourida are missing*.

" By the annexed table it will also be seen that several remarkable Papuan forms belonging to another characteristic Papuan family (Alcedinida) are not found in Celebes.

\footnotetext{
* Calcenas is a migratory form.
} 
“TABLE VI.-Showing the principal Austro-Malayan or Papuan genera which do not occur in Celebes.

$\begin{array}{lll}\text { Henicopernis. } & \text { Petroica. } & \text { Gymnocorvus. } \\ \text { Podargus. } & \text { Peltops. } & \text { Eos. } \\ \text { Agotheles. } & \text { Macharirhynchus. } & \text { Lorius. } \\ \text { Eurystopodus. } & \text { Arses. } & \text { Geoffroyius. } \\ \text { Choucalcyon. } & \text { Monarcha. } & \text { Charmosyna. } \\ \text { Mellidora. } & \text { Piezorhynchus. } & \text { Platycercus. } \\ \text { Cyanalcyon. } & \text { Microca. } & \text { Psittacula (Cyclo- } \\ \text { Syma. } & \text { Todopsis. } & \text { psitta). } \\ \text { Alcyone. } & \text { Mimeta. } & \text { Nasiterna. } \\ \text { Myzomela. } & \text { Rectes. } & \text { Microglossum. } \\ \text { Entomophila. } & \text { Cracticus. } & \text { Dasyptilus. } \\ \text { Glyciphila. } & \text { Pachycephala. } & \text { Trogon. } \\ \text { Meliphaga. } & \text { Myiolestes. } & \text { Goura. } \\ \text { Anthochara. } & \text { Manucodia. } & \text { Henicophaps. } \\ \text { Philemon. } & \text { Ptilonorhynchus. } & \text { Casuarius. } \\ \text { Gerygone. } & \text { Lycocorax. } & \end{array}$

" The zoogeographical relationship of the Philippines and Celebes, as exemplified by their birds, has been adverted to by Mr. Wallace and other writers. Unfortunately the Philippine archipelago, with its twelve hundred islands, has been but imperfectly explored; while the localities of many, if not of all the known Philippine species are but vaguely ascertained. Luzon, the island whose ornithology has been the most investigated, is the furthest off from Celebes, and has the large island of Mindanao and many of less importance intervening. The resemblance which exists between the Celebean and Philippine avifaunas rests on the occurrence of Papuan genera in Mindanao, and perhaps in South Luzon, which likewise occur in Celebes: Cacatua, Cyclopsitta, Tanygnathus, Phlegonas *, Hemiphaga, and Megapodius may be cited. Two genera seem to be confined to Celebes and the Philippines-Prioniturus and Pyrrhocentor; this last is only known from Mindanao. Megapodius cumingi (Gould) is stated by Camel (v. Martens, op cit.) to be found at Tabon in Mindanao and in Mindoro. The exact habitats of the other genera remain to be determined. The known Philippine genera of the Picarice and Passeres are nearly all Indo-Malayan; but then they have mostly been as yet only obtained from the neighbourhood of Manilla. They include characteristic Indian genera unknown in Celebes. Such are, besides Hierax, Harpactes, Chrysocolaptes, and several other Picida, Xantholama, Irena, Copsychus, Cittacincla, Tchitrea, Ixos, Hypsipetes, Purus, and genera such as Lanius and Turdus.

"That Mindanao contains a strong Indian element, however, is shown by the fact that Xantholama, Irena, and Copsychus have been there obtained; Irena also occurs in the island of Panay. Thus enough is known of the Philippine ornis to justify anticipation, when worked out, of highly interesting zoogeographical facts, but

* Phlegcenas luzonica (Scop.), = cruenta $(\mathrm{Gm}$.), is said by Bureta to occur in the Calamines (conf. v. Martens, J. für O. 1866, p. 25). 
not sufficient to enable us to determine the degree of relationship between the avifauna of the Philippine and Celebean areas.

"The absence of the two genera Criniger and Rhipidura in Celebes constitutes one of the many peculiarities of its ornis. Criniger, represented in the neighbouring Sula Islands by a peculiar species, possesses other representatives in many of the Moluccan islands and throughout the Indo-Malayan subregion.

"Rhipidura is still more widely and largely represented in the whole Australian region, and in the Indo-Malayan subregion, having representatives in all the islands of the Malay archipelago, excepting Celebes and the Sula Islands.

"Then, again, the presence of the two genera Coracias and Myialestes is equally remarkable; for they are both unknown in any part of the Indo-Malayan region, and only reappear on the mainland of Asia.

"After rejecting all those species whose Celebean origin does not rest upon the most undoubted authority, I find that the number of birds inhabiting Celebes amounts to, at least, one hundred and ninety-three. Of this number sixty-five are peculiar to the island. Twenty more are found also in the Sula Islands, or the Sanghir group, making a total of eighty-five species peculiar to Celebes and the two gronps just mentioned. Of the remaining one hundred and eight species, fifty-five have Indian affinities (that is, are elsewhere only found in the Indian region as opposed to the Australian), though many extend beyond the limits of the Indian region; fourteen are found in the Australian and not in the Indian region, and twentyeight are common to both regions; eight more species seem to be confined to the Moluccan islands; and three, not included above, are doubtfully found beyond Celebes: these are Elanus hypoleucos, Ephialtes menadensis, and the Celebean form of Iotreron melano-
cephala."

This paper will be published entire in the Society's 'Transactions.'

The following papers were read :-

1. A Revised Catalogue of the Birds of China and its Islands, with Descriptions of New Species, References to former Notes, and occasional Remarks. By RoBert Swinhoe, F.Z.S.

[Received March 15, 1871.]

1. Gypä̈tus barbatus, Cuv. ; Ibis, 1867, p. 413 ; P. Z. S. 1870 , p. 430 .

I have seen, in the museum attached to the Catholic Mission at Pekin, a Bearded Vulture, procured by Père Armand David in the mountains west of that city. There is aiso a specimen of it in the British Museum, marked "China."

Proc. Zool. Suc.-1871, No. XXII. 
2. Vultur monachus, L.; Ibis, 1867, p. 413.

There are specimens of this Vulture in the Peking Museum, procured by Père David from the mountains in the north-west of the Chelee Province.

\section{Aquila chrysä̈tos, Cuv.; P. Z. S. 1870, p. 443.}

Eagles were several times seen by myself in the Nankow Pass, on the road from Peking to Mongolia, but I was not able to determine the species. Père David identifies the resident species of these mountains with the Golden Eagle, and mentions meeting with a large variety, with longer bill and white tarse ("Catalogue des oiseaux à Pékin," Nouv. Arch. du Muséum d'Hist. Nat. de Paris, tome iii. 1867), which Mr. Gurney tells me he has seen from Denmark and also from Algeria. Mr. Gurney adds that " the specimens were in other respects in the usual plumage of the second year. The Danish examples were certainly large and fine, the Algerian not particularly so. At present I have seen no sufficient difference to make me think that there are two species or races of Golden Eagle."

\section{Aquila bifasciata, J. E. Gray.}

Aquila heliaca, P. Z. S. 1863, p. 259; Ibis, 1865, p. 347 .

Mr. Howard Saunders has demonstrated to this Society* that the eastern form of Imperial Eagle differs, in its first plumage at least, from the European bird, and is apparently a distinct species. M. Milne-Edwards refers to Dr. Gray's name a bird sent from Pekin by Père David, on which the Abbé remarks, " common on our mountains and in Mongolia." This species has been shot in the immature plumage in winter at Foochow; and $I$ have noticed it in adult plumage with white scapulars on Ape's Hill, Takow, S.W. Formosa.

5. Aquila amurensis, sp. nov.

Similis A. clangæ, Pall., sed major.

M. Milne-Edwards identifies the Tawny Eagle from Peking with $A$. clanga of Pallas; and Pére David notes the occurrence also at the same locality of the smaller allied form, $A$. navia, Briss. A specimen from the Amoor, kindly sent me by Dr. v. Schrenck, is of large size, and, in Mr. Gurney's opinion, worthy of separation as a third species of this group. I enter this in the present list under the supposition that it will be the same as No. 5 of Père David's catalogue, which he also states to be "common in our mountains and in Mongolia." Mr. Gurney very obligingly compared the Amoor specimen with a female of Aquila clanga from Sarepta, on the Volga, and has given me the following measurements :-

$\begin{array}{lccccc} & \begin{array}{c}\text { Entire } \\ \text { length. }\end{array} & \begin{array}{c}\text { Wing from } \\ \text { carpel joint. }\end{array} & \text { Tail. } & \text { Tarsus. } & \begin{array}{c}\text { Middle toe } \\ \text { without claw. }\end{array} \\ \text { A. clanga }+ \text { (ad.)... } & 31 \text { in. } & 23 \text { in. } & 11 \text { in. } & 3 \frac{1}{2} \text { in. } & 2 \frac{1}{4} \text { in. } \\ \text { A. amurensis } q \text { (ad.) } & 33 \frac{1}{2},, & 26 \frac{1}{4},, & 12 \frac{1}{2},, & 4 \frac{1}{2},, & 2 \frac{1}{4},,\end{array}$

Mr. Gurney writes :- " In plumage, I do not find that it differs * See anteà, p. 37. 
from the adult of $A$. clanga, except in having the pale transverse bars on the secondaries lighter in their hue, and therefore more conspicuous, especially on the outer webs.

"It would seem that there are three races of Eagles, only differing in comparative size :-

"Aquila navia. The smallest of the three, found in Egypt, Southern Europe, Smyrna, Palestine, India, and Sumatra (one specimen).

"Aquila clanga, Pall. The intermediate race, found at Sarepta, near the mouth of the Volga. Both it and the preceding have been obtained in European Turkey and in Palestine. I have also seen the Sarepta race from Mesopotamia ; but how far it extends eastward I do not know.

"Aquila (from Amoorland). The largest race. How far it extends westward I do not know."

6. Haliä̈tus albicilla (L.); Ibis, 1865 , p. 347 ; P. Z. S. 1863, p. 259.

From the river Yangtsze northwards. Seen only occasionally in the south. An immature bird flew on board a ship in the harbour of Swatow, and allowed itself to be captured, in the winter of 1867-68. It fell into my hands. Its iris was clear yellowish brown; cere light bluish grey; feet lemon-yellow, with black claws.

7. HaliaËtus pelagicus, Pall.; P. Z. S. 1863, p. 260.

Père David saw this giant Eagle once at Peking, and says that it is well known to the Chinese.

\section{Archibuteo aquilinus, Hodgs.}

Butaquila aquilina et B. leucocephala, Hodgs.

Butaquila hemilasius, Schleg. Faun. Jap.

Buteo lagopus, David, Catalogue des oiseaux à Pékin.

Falco hemilasius, Temm. et Schleg. Faun. Jap.

In January 1868 a large male Buzzard was shot by Consul Caine at Swatow. Mr. Gurney has determined it to be of this species. Its cere was greenish yellow ; iris straw-yellow, redder rourd the pupil; legs dingy orange-tinted yellow, with black claws. It is not in mature plumage. Père David has sent specimens of the same to the Paris Museum, and writes that it is not rare at Pekin and breeds there.

9. Buteo asiaticus (Lath.).

Buteo japonicus, Temm. et Schleg. Faun. Japon.; Zoologist, 1858, p. 6227; Ibis, 1860, p. 46, 1861, pp. 24, 326, 1863, pp. 210 , 1870 , p. 87 ; P. Z. S. 1863 , p. 260.

South China to Hainan, and Formosa in winter.

10. Spizaëtus nipalensis, Hodgs.

Spizaëtus orientalis, Temm. et Schleg. Faun. Japon.; Swinhoe, Ibis, 1863 , p. 211.

Formosa. 
11. Spilornis cheela (Daud.).

Spilornis hoya, Swinhoe, Ibis, 1866, pp. 304, 307, 399, 1867, pp. $409,410$.

Formosa ; Amoy (China).

12. Spilornis rutherfordi, Swinhoe, Ibis, 1870 , p. 85.

Hainai.

13. Poliornis poliogenys (Temm. et Schleg.); Swinhoe, Ibis, 1863 , p. 88,1864 , p. 429 , 1865 , p. 545 , 1866 , p. 136 , 1867 , p. 411 ; P. Z. S. 1862 , p. 315,1863 , p. 260 , 1870, p. 600.

Buteo pygmaus, Blyth, Ibis, 1865, p. 29.

Formosa ; coast of China. Goes as far south in winter as the Tenasserim Provinces.

14. Pandion haliaËtus (L.); Swinhoe, Zoologist, 1858, p. 6227, 1860 , p. 7102 , 1861, p. 7642 , 1864, p. 9224 ; Ibis, 1860 , p. 46, 1861 , p. 24,1863 , p. 209 , 1865 , p. 347 , 1870 , p. 86 ; P. Z.S. 1863 , p. 260.

Throughout China, Formosa, and Hainan.

15. Falco peregrinus, L. ; Zool. 1858, p. 6226 ; Ibis, 1860, p. 46,1861 , p. 24,1863 , p. 210,1867 , p. 388,1870 , p. 84 ; P. Z. S. 1863 , p. 260.

China, Formosa, and Hainan.

16. Falco Sacer, Schlegel; P. Z. S. 1863, p. 260.

Buteo — ?, Ibis, 1861, p. 326, 1863, p. 88.

Peќin.

17. Hypotriorchis subbuteo (L.); Ibis, 1860, p. 46, 1863, p. 89.

Falco subbuteo, P. Z. S. 1862, p. 315, 1863, p. 260.

Amoy ; Pekin.

18. Hypotriorchis eSALON (L).

Falco asalon, Ibis, 1861, p. 327 ; P. Z. S. 1863, p. 260.

Amoy ; Pekin.

19. Tinnunculus alaudarius, var. Japonicus.

Tinnunculus alaudarius, Swinh. Ibis, 1860, p. 47, 1861, p. 24, 1866 , p. 293,1867 , p. 385,1870 , p. 84.

Falco tinnunculus, Ibis, 1861, p. 327.

Tinnunculus japonicus, Ibis, 1863, p. 211, 1864, p. 424 ; P. Z.S. 1863, p. 261.

China, Formosa, and Hainan.

20. Erythropus amurensis (Radde); Gurney, Ibis, 1868, p. 41 , pl. 11 ; P. Z. S. 1870, pp. 436, 448.

Erythropus vespertinus, Ibis, 1861, pp. 253, 327 ; P. Z. S. 1862 , p. 315,1863 , p. 260. 
Summers at Pekin, and collects in large numbers in September before going south. Wanders in winter to India and Atrica.

\section{TICHORNIS PEKINENSIS.}

Falco cenchris, var. pekinensis, Swinhoe, P. Z. S. 1870, pp. 442, 448.

Breeds on the western hills of Pekin, and assembles in large numbers in September. Mr. Hodgson's drawing of the Nepal bird (in the British Museum) shows that it is this race of Tichornis cenchris that resorts to India.

The adult male has all the wing-coverts grey right up to the scapulars; the inner or short primaries are broadly bordered at their tips with whitish, rufous in the immature; the white on the under quills is $3 \frac{1}{4}$ inches short of their tips.

22. Pernis apivorus (L.); David, Catalogue des oiseaux à Pékin.

Père David notes this as found about Pekin in autumn. Schlegel has it from Japan (Musée des Pays-Bas, Pernes, p. 2).

23. Milvus Govinda, Sykes; Swinh. Zoolog. 1858, p. 6227 ; Ibis, 1860 , p. 47,1861 , pp. $25,253,326,1863$, p. 210,1865 , p. 546 , 1866 , p. 121,1867 , p. 236 , 1870 , p. 88.

Milvus melanotis, Ibis, 1865, p. 348, 1867, pp. 409, 411 ; P.Z.S. 1863, p. 260.

China, Formosa, and Hainan.

24. Milvus migrans (Bodd.).

Milvus ater, $\mathrm{Gm}$.

A live specimen of this Kite, said to have been brought from North China, is now living in the Society's gardens.

25. Astur palumbarius (L.) ; P. Z. S. 1863, p. 261, 1870, p. 448.

I have an adult male from Pekin, which does not differ from home-shot specimens.

26. Lophospiza trivirgata (Cuv.); Temm. Pl. Col. 303; Ibis, 1865 , p. 547,1866 , p. 395.

Formosa. The Malay form.

27. Accipiter nisus (L.) ; Zoolog. 1858, p. 6227 ; Ibis, 1861, p. 327,1870 , p. 84 ; P. Z. S. 1863 , p. 261,1870 , p. 443.

Accipiter —? Ibis, 1860, pp. 47, 429, 1863, p. 88.

Peking, Amoy, and Canton.

28. Accipiter stevensoni, Gurney; Ibis, 1863, p. 447, pl. 11 ; P. Z. S. 1863 , p. 261 , 1870 , p. 600.

Micronisus, sp.?, Ibis, 1861, p. 25.

Accipiter gularis?, Ibis, 1863, p. 89.

Canton to Pekin. 
29. Accipiter gularis, Schleg. F. J.t. 2 ; Gurney, Ibis, 1865, pp. 236,547 ; P. Z. S. 1863 , p. 261.

Accipiter nisoides, Blyth, Ibis, 1865, p. 28.

Formosa.

30. Accipiter virgatus, Temm. Pl. Col. 109 ; Ibis, 1865, p. 108, 1866, p. 405.

Micronisus gularis, Ibis, 1863, p. 212.

Formosa.

31. Micronisus badius (Gm.); Swinh. Ibis, 1870, p. 84 .

Hainan.

32. Micronisus soloënsis (Horsf.); Pl. Col. 110, 129 ; Ibis, 1863 , p. 89 , 1866, p. 403 ; P. Z. S. 1862 , p. 315 , 1863, p. 261.

Micronisus badius, Ibis, 1860, p. 359.

Accipiter virgatus, Ibis, 1861, p. 264.

Amoy ; Pescadores ; Shanghai (Brit. Museum); Pekin.

33. Circus aruginosus, L. ; Ibis, 1865, pp. 349, 352, 1870, p. 87.

Swatow ; Amoy ; S.W. Formosa ; Hainan.

34. Circus spilonotus, Kaup ; Ibis, 1863, p. 213, pl. 5, 1865, pp. $230,347,1870$, p. 87 ; P. Z. S. 1863 , p. 261.

Circus aruginosus, Ibis, 1860, pp. 47, 359.

Amoy ; river Yangtsze; Formosa.

35. Circus cyaneus, L. ; Zoolog. 1858, p. 6227 ; Ibis, 1860, p. 47,1861 , p. 326,1870 , p. 88 ; P. Z. S. 1863 , p. 261.

Amoy.

36. Circus melanoleucus, Gm.; P. Z. S. 1862, p. 315, 1863, p. 261.

Circus — ?, Ibis, 1861, p. 326 , 1863, p. 88.

Tientsin.

37. Circus cineraceus, Montagu.

River Yangtsze.

38. Circus pallidus, Sykes.

Circus swainsonii, A. Smith ; P. Z. S. 1863, p. 261.

River Yangtsze.

39. Athene Plumipes, Swinhoe, P. Z. S. 1870, p. 448.

Similis A. glauci, sed pedibus dense plumatis.

Not common about the Pekin neighbourhood in autumn; is found also in the Lake-Baikal region, according to Tacsanowsky of Warsaw. 
40. Athene whitelyi, Blyth, Ibis, 1867, p. 313.

Athene cuculoides, Ibis, 1861, pp. 25, 265, 1867, p. 406 ; P. Z. S. 1863, p. 262.

$A b \mathrm{~A}$. cuculoidi alarum et cauda fasciis paucioribus distinguenda.

Amoy; Canton; Foochow; Szechuen. Goes south on the approach of winter.

41. Athene brodiei (Burt.).

Noctua brodiai, Burt. P. Z. S. 1835.

Tingchow (Fokien Province). One specimen of this was brought to me at Amoy in January 1867.

42. Athene pardalota, Swinhoe; Ibis, 1863, p. 216.

Differt a sp. pracedente ventre medio nigro guttato.

Formosa.

43. Ninox Japonica, Temm. et Schleg.; Zool. 1858, p. 6228 ; Ibis, 1863 , pp. $89,215,1864$, p. 427,1866, p. 307,1870 , p. 88 ; P. Z. S. 1862, p. 316, 1863, p. 262.

Athene scutellata (Raffles); Ibis, 1860, p. 47.

Amoy ; Hainan ; Formosa ; Tientsin.

44. Вuво махімus, Sibb.; Zool. 1858, p. 6227 ; Ibis, 1860, p. 47,1861 , pp. 254,327 ; P. Z. S. 1863 , p. 262.

Amoy, North China.

45. Ketupa Ceylonensis (Gmel.); Ibis, 1861, p. 27 ; P. Z. S. 1863, p. 262.

Hongkong.

46. Scops sunia, Hodgs.

Scops japonicus, Schleg. Faun. Japon.; Zool. 1858, p. 6228; Ibis, 1863, p. 89 ; P. Z. S. 1863, p. 262.

Scops bakkamœena (Penn.); Ibis, 1860, p. 47; P. Z. S. 1862, p. 316. Amoy in winter; Pekin.

47. Lempijius Semitorques (Schleg.).

Ephialtes plumipes, Hume, Scrap Book, Part 1, No. 2, p. 307.

Digitis supra plumatis.

Schlegel (Mus. des Pays-Bas, Oti, p. 24) cites specimens from Japan and Nepal. Père David has sent it from Moupin (N.W. corner of Szechuen).

48. Lem PIJIUS GLABRIPES.

Ephialtes glabripes, Swinh. Ann. \& Mag. Nat. Hist. vol. vi. 4th series, p. 152.

Scops semitorques, Swinh. (nec Schlegel), Ibis, 1863, p. 217, 1867 , p. 409 ; P. Z. S. 1863 , p. 262. 
Scops —?, Ibis, 1861, p. 29.

Scops lempiji, Ibis, 1861, p. 265.

Digitis nudis.

Amoy ; Foochow ; Canton ; Formosa. Differs from the foregoing in having the toes always bare instead of feathered along their upper surfaces.

49. Lempijius umbratilis, Swinh. Ibis, 1870, p. 342 .

Ephialtes lettia, Ibis, 1870, p. 88.

Hainan.

50. LeMPIJIUS HAMBROECKI.

Ephialtes hambroecki, Swinh. Ann. \& Mag. Nat. Hist. vol. vi. 4th series, p. 153.

Scops japonicus, Ibis, 1865, p. 348,1866 , p. 307.

Formosa. Of the Lempiji form and type, but small and rufous, and at first sight to be mistaken for Scops japonicus.

51. Syrnium nivicolum, Hodgs. J. A. S. xiv. p. 185 ; P. Z. S. 1870, pp. 438, 443.

Pekin in autumn.

52. Ptynx fulvescens (Temm. et Schleg.).

Sent to the Paris Museum by Père David from the Moupin Mountains (N.W. Szechuen).

53. Bulaca newarensis (Hodgs.).

Bubo caligatus, Swinh. Ibis, 1863, p. 218, 1864, p. 429.

Formosa.

54. Otus vulgaris, Flem. ; Ibis, 1863, p. 89 ; P. Z. S. 1862 , p. 316,1863 , p. 262.

Tientsin.

55. Otus brachyotus (L.) ; Ibis, 1861 , pp. 26,327, 1863, p. 89 ; P. Z.S. 1863, p. 262.

Peking; Canton.

56. Strix Candida, Tickell.

Strix pithecops, Swinhoe, Ibis, 1866, pp. 396, 397.

S.W. Formosa.

57. Caprimulgus Jotaka, Temm. et Schleg. F. J. ; Ibis, 1861 , p. 327,1870 , p. 89 ; P. Z. S. 1863 , p. 263 , 1870, p. 439.

Caprimulgus _- ?, Ibis, 1860, p. 47, 1861, p. 30.

Caprimulgus dytiscivorus, Swinh. Ibis, 1860, p. 130.

Caprimulgus swinhoei, Blyth; Ibis, 1861, p. 263.

China. 
58. Caprimulgus monticola, Frankl. P. Z. S. 1831, p. 116.

Caprimulgus stictomus, Swinh. P. Z. S. 1863, p. 263.

Caprimulgus pallidus, Gray, Zool. Misc. p. 2.

Caprimulgus - ? ? Ibis, 1860, p 47, 1861, p. 30.

South China in summer. I have a very rufous and brightly marked female from Amoy, which I at first confounded with the following bird.

59. Caprimulgus stictomus, Swinhoe, Ibis, 1863, p. 250, 1866, pp. 315, 402 .

Like the last, but smaller, with the toes, especially the middle one, conspicuously longer. Resident in Formosa.

60. Cypselus pekinensis, Swinhoe, P. Z. S. 1870, p. 435.

This pale representative of $C$. apus, L., comes to Pekin in large numbers in April (David) to breed, and leaves early in August. A bird from the Himalayas, brought home by Dr. Jerdon, agrees with my specimens; and it is probably this species, and not the true $C$. apus, which is found in India in winter.

61. Cypselus Pacificus, Lath. Ind. Orn. Suppl. p. 58 ; Ibis, 1870 , p. 89.

Cypselus vittatus, Jard. Ill. Orn. ser. 2. pl. 39 ; Ibis, 1860, pp. $48,429,1861$, pp. $254,328,1863$, p. 253,1865 , p. 356 ; P. Z. S. 1863 , p. 263.

Hainan to Pekin, and in Formosa.

62. Cypselus subfurcatus, Blyth; Ibis, 1863, p. 254, 1865, p. 355,1866 , p. 131,1867 , p. 227,1870 , p. 89 ; P. Z. S. 1863 , p. 264.

Cypselus affinis, Ibis, 1860, p. 48, 1861, p. 30.

Hainan to Amoy, and in Formosa.

63. Cypselus infumatus; Sclater, P. Z. S. 1865, p. 602.

Cypselus tinus, Swinh. Ibis, 1870, p. 90.

Cypselus tectorum, Jerdon.

Hainan. I have compared my specimens with Dr. Jerdon's type from Upper Assam, and with Dr. Sclater's type from Borneo in Mr. Wallace's collection, and find them all to be of the same species.

64. Chemtura caudacuta (Lath.).

Hirundo ciris, Pall. Zoograph. Rosso-Asiat.

Acanthylis caudacuta (Lath.), P. Z. S. 1863, p. 263.

Chatura nudipes, Hodgs. ; Ibis, 1860, p. 48.

Amoy. Common on the Pekin mountains (David).

65. ? Chetura gigantea, V. Hass.; Pl. Col. 364.

Acanthylis caudacuta, Ibis, 1870 , p. 90.

It is probably this species that makes the edible nests in the cares 
of the islands off the south of Hainan, and not the preceding species, as I had at first supposed.

66. Hirundo Gutturalis, Scop. ; Ibis, 1860, pp. 48, 429, 1861 , p. 30,1863 , p. 255,1870 , p. 240 ; P. Z. S. 1863 , p. 287.

Hirundo rustica, Ibis, 1861 , p. 254, 328, 1863, p. 89, 1867, p. 411.

Hirundo panayana, Gmel. Syst. Nat. 1788, i. p. 1018.

Throughout China and Formosa in summer. Like H. rustica, but much smaller and with broader bill.

67. Cecropis striolata (Temm. \& Schleg.).

Hirundo daurica, Ibis, 1860, p. 48, 1863, p. 255.

The striped-belly Swallows that abound in summer in Formosa and breed there belong to the species of this group found in the islands of the Indian archipelago. My specimens agree with one collected by Mr. Wallace at Flores. Seven specimens of this form show no signs of a white spot on the inner web of the outer rectrix.

68. Cecropis Japonica (Temm. \& Schleg.).

Hirundo daurica, Ibis, 1860 , p. 48 ; P. Z. S. 1863 , p. 187.

I believe my Amoy specimens to belong to this species, though I have not been able to compare them with skins from Japan. Hirundo erythropygia, Sykes, of India (Gould, B. of As. pl.) is easily distinguished from this by its deep rufous unstreaked rump, and by the faint narrow streaks of its underparts. An occasional specimen of our bird shows a faint white spot on the inner web of the outer rectrix.

69. Cecropis arctivitta, n. sp.

Hirundo daurica, Ibis, 1861 , p. 328,1863 , p. 89 ; P. Z. S. 1863 , p. 287.

The striped Swallow that comes to Pekin to breed is of about the size of the Amoy species, but more faintly and narrowly striped on the underparts, and is easily distinguishable from that and all other species of this group that $I$ have seen by the extreme narrowness of the rufous band across its rump. (Depth of band in $C$. japonica $1 \cdot 2$, in this bird $\cdot 7$ ). I was formerly under the impression that the Pekin bird was the true H. daurica, L. (H. alpestris, Pall.); but $I$ have now no doubt that both Linnæus and Pallas applied their names to H. rufula, Temm. (Gould, B. of As. pl.). The Himalayan species, $H$. nipalensis, Hodgs. (H. daurica, Gould, B. of As. pl.), has the rump-band nearly as narrow as in ours, but its broad rufous nuchal collar prevents its being confounded with ours. The white spot on the external rectrix is also occasionally seen in the Pekin birds.

70. Сotyle riparia (L.); Ibis, 1861, p. 328, 1863, p. 89 ; P. Z. S. 1863 , p. 287.

Pekin in summer. 
71. Cotyle sinensis (J. E. Gray); Swinh. Ibis, 1863, p. 257, 1866, p. 134 ; P. Z. S. 1863, p. 288.

South China and Formosa.

\section{Ptyonoprogne rupestris.}

Cotyle rupestris (Scop.); P. Z. S. 1870, p. 445.

Common in the mountains about Pekin. Père David says that in winter many are found together in caverns in a torpid state, and that these on mild days recover from their sleep and fly about over the rocks in the open.

73. Chelidon tagopoda (Pall.); Ibis, 1863, p. 91 ; P. Z. S. 1863, p. 287.

Chelidon whiteleyi, Swinh. P. Z. S. 1862, p. 320.

Seen in summer about the hills of Pekin and of Ichang, up the Yangtsze. Very scarce. Père David found it nesting in the rocks of San Yu. It avoids the neighbourhood of houses.

74. Eurystomus orientalis (L.) ; Ibis, 1860 , p. 48, 1861, p. 31,1866 , p. 129 ; P. Z. S. 1863 , p. 269.

Canton; Foochow. A summer visitant. Does not quite agree with specimens from India, nor yet with those from Java and Lombock.

75. Halcyon smyrnensis (L.) ; Gould, B. of As. pl. ; Ibis, 1860 , p. 48,1861 , p. 31,1868 , p. 59,1870 , p. 93 ; P. Z. S. 1863, p. 269.

Shanghai to Hainan.

76. Halcyon pileatus, Bodd. Pl. En. 673 ; Ibis, 1860, p. 49, 1870 , p. 93.

Halcyon atricapilla, P. Z. S. 1863, p. 269.

Hainan to Pekin.

77. Halcyon coromandeliana, Scop. Ibis, 1863, p. 259.

Halcyon coromanda, Ibis, 1866, p. 138.

Formosa.

78. Alcedo bengalensis, Gm.; Swinh. Ibis, 1860 , p. 49 , 1861, pp. 31, 328, 1863, p. 260, 1867, p. 408, 1870, p. 92 ; P.Z. S. 1863, p. 269.

Hainan to Peking, and in Formosa. The bird in Formosa is usually to be distinguished from the continental race by a blue spot on each side of the breast near the bend of the wing; but this peculiarity occurs also occasionally in birds on the main.

79. Ceryle rudis (L.) ; Ibis, 1860, p. 49, 1861, p. 31, 1867, p. 408 , 1870 , p. 92 ; P. Z. S. 1863 , p. 269.

Hainan to Wanchow, and upper waters of the Yangtsze. Chinese specimens rarely have white spots on the black band of the tail. 
80. Cerrye lugurris, Temm. Pl. Col. 548.

A bird shot at Ningpo and described to me by a friend answers to this species.

81. Merops daudini, Cuv.; G. R. Gray's Hand-list of Birds.

Merops philippensis, Ibis, 1865, pp. 230, 348, 1870, p. 91.

Merops philippinus, Ibis, 1866, p. 129.

Procured at Swatow. For the edification of our Indian friends it is well to state here that the so-called $M$. quinticolor from India is not the same as the Javan bird. The former differs from the latter in having the under neck blotched with chestnut, and the tail green instead of blue. The Indian species should stand as $M$. erythrocephalus, Brisson, Av. iv. p. 563.

82. UpUPA EPOPS, L.; Zool. 1858, p. 6229 ; Ibis, 1860, p. 49, 1861, pp. 254, 328, 1867, p. 236 ; P.Z.S. 1863, p. 264.

From Canton to Pekin. I described in the 'Zoologist' for 1858 , and in the P.Z.S. for 1863 , the peculiar way in which the Hoopoe produces its notes, by puffing out the sides of its neck and hammering on the ground at the production of each note, thereby exhausting the air at the end of the series of three which make up its song. Before it repeats its call it repeats the puffing of the neck, with a slight gurgling noise. When it is able to strike its bill the sound is the correct " hoo-hoo-hoo ;" but when perched on a rope and only jerking out the song with nods of the head, the notes more resemble the syllables "hoh-hoh-hoh." Mr. Darw in makes use of this last fact to show that some birds have instrumental means to produce their music (Descent of Man, ii. p. 62). It is not to this point, however, that I wish at present to call attention; but to the fact of the bird's puffing out the sides of its neck. It is generally supposed that the song of a bird is produced by actions of the lower larynx on air passing up the bronchial tubes, onwards and outwards through the main tube or trachea. The trachea of the Hoopoe is not dilatable ; but its œsophagus is ; and the puffing of its neck is caused by the bulging of its œsophagus with swallowed air. There is no connexion between the œsophagus and the trachea, and apparently no organ at the entrance to the former that could modify sound; what action, then, can this swallowed air be made to take in the production of the bird's notes? Pigeons have strikingly large air-crops, which they empty with each long coo, and refill before they coo again. Many birds swell out the throat when calling or singing, and others move it up and down; these actions must also be caused by the swallowed air in the œsophagus, and must modify the sounds in some way as variously used, adding power and richness in some cases, or giving ventriloquistic effect in others. This question seems never to have been inquired into before; and I throw out the hint in hopes that others may help to elucidate the matter with their investigations. As regards Pigeons, Mr. W. B. Tegetmeier suggests " that the dilated œsophagus and crop serve as a chamber of resonance, the air in 
which, being thrown into vibration, may be expelled to produce a louder sound."

83. UPUPA Ceylonensis, Reichenbach; Blyth, Ibis, 1966, p. 366,1870 , p. 91 .

Upupa longirostris, Jerdon, Birds of India, i. p. 393.

Hainan. Also from Java and Ceylon (Cabanis); Siam and Burmab. My skins from Hainan agree perfectly with a specimen from Burmah sent me by Mr. Blyth.

84. Eтhopyga christine, Swinh. Ann. \& Mag. Nat. Hist. 4 th ser. vol. iv. p. 436 ; Ibis, 1870 , p. 236.

Hainan.

85. Æтhopyga abriı, J. Verr. Rev. et Mag. de Znol. 1867, p. 173, pl. 15 .

Western Szechuen (David); Western Yunnan (Anderson).

86. Arachnechthra rhizophora, Swinh. Ann. \& Mag. Nat. Hist. 4th ser. vol. iv. p. 436 ; Ibis, 1870 , p. 237.

Hainan. To distinguish this from its ally $A$. flammaxillaris, Blyth, I gave the character of its frontal feathers being iridescent like its throat. M. Jules Verreaux, however, has a specimen from Penang with the forehead showing a few feathers of the same mark. A more constant distinguishing character would appear to be the paleness and dinginess of the yellow of the belly and underparts iis our bird as contrasted with the bright yellow of the same in its ally.

87. Dicaum cruentatum, L. ; Ibis, 1867, p. 405 , 1868, p. 63 , 1870, p. 239.

Fokien ; Hongkong; Hainan.

88. Dicaum minullum, Swinh. Ibis, 1870, p. 240.

Hainan.

89. Myzanthe ignipectus, Hodgs.

Tingchow (Fokien Province). I would here note that a specimen of Piprisoma agile, Tickell, from India, collected by Mr. Beavan, seems to me undistinguishable from another of Prionochilus obsoletus (Müll. \& Schleg.) from Flores, collected by Mr. Wallace.

90. Zosterops simplex, Swinh. P. Z. S. 1862, p. 317,1863 , pp. 203, 297 ; Ibis, 1863 , p. 294 , 1866, p. 121 , 1870 , p. 348.

Zosterops, sp., Zool. 1858, p. 6229.

Zosterops japonicus, Ibis, 1860, pp. 55 \& 131, 1861, p. 35.

Hainan to Wanchow, and in Formosa. 
91. Zosterops erythropleura, Swinh. P.Z. S. 1863, pp. 204, 298, 1870, p. 448.

Zosterops japonicus, Ibis, 1861, p. 331 ; P. Z. S. 1862, p. 317. Shanghai to Pekin.

92. Zosterops subroseus, Swinh. P. Z. S. 1870, p. 132.

Hankow.

93. Sitra villosa, Jules Verreaux, Nouv. Arch. du Muséum, tome i., Bull. p. 78, pl. 4 ; P. Z. S. 1870, pp. 436, 438.

Sitta pekinensis, David, Cat. des ois. à Pékin; Swinh. P. Z. S. 1870, p. 438.

Pekin. Allied to S. canadensis, L., of North America.

94. Sitta amurensis, n. sp.

The Nuthatch from Amoorland, instead of being white-bellied like that from Trans-Baikal and Northern Japan, is rufous underneath, approaching in that respect $S$. casia of England and Western Europe. It differs from that species, however, in its shorter bill and tarse, and more slender legs and toes. It has a distinct white eyebrow, its under neck and breast are pure white, and its belly and flanks buff; its under tail-coverts deep cinnamon, spotted with white. It otherwise agrees with $S$. casia, and is of about the same size. It ranges down to Pekin in winter.

95. Sitta sinensis, J. Verr. MS. ; Ibis, 1865, p. 107.

I observed a small Nuthatch near Ningpo, but did not succeed in securing it. Père David sent to Paris a single specimen of the same from Kinkiang, which will be described by M. J. Verreaux in due course. A larger form of the same type has been sent by Père David from the Moupin Mountains.

96. Certhia familiaris, L.; P. Z. S. 1863, p. 270.

Certhia fasciata, David, Cat. des ois. à Pékin.

A rare visitant to Pekin in winter (David). I have a specimen from Pekin from Père David, and another from Amoorland from V. Schrenck, which do not appear separable from the home species.

97. Certhia himalayana, Vig.

Received at the Paris Museum through Père David from the Moupin Mountains (N.W. Szechuen).

98. Tichodroma muraria, L.; P. Z. S. 1863, p. 270.

Foochow ; Pekin (David).

99. Pnoepyga squamata (Gould).

Sent to the Paris Museum from the Moupin Mountains by Père David. 
100. Troglodytes fumigatus, Temm. Man. d'Ornithol. iii. p. 161 .

Pekin (David).

101. Orthotomus lungicauda (Gm.); Swinh. Zool. 1858, p. 6229 .

Motacilla longicauda, Gmel. Syst. Nat. 1788, i. p. 954.

Orthotomus phyllorrhapheus, Swinh. Ibis, 1860, p. 49, 1861, p. 32, 1862, p. 258; P. Z. S. 1863, p. 294.

South China. Gmelin's name applies specially to the China bird, so that its Indian ally will have to take the next in priority of its numerous synonyms.

102. Prinia sonitans, Swinh.; Zool. 1858, p. 6229; Ibis, 1860 , p. 50,1861, p. 32 , 1863 , p. 302,1870 , p. 345 ; P. Z. S. 1863, p. 294.

South China; Hainan; Formosa.

103. Horeites robustipes, Swinh. Ibis, 1866, p. 398.

Formosa. Like Horornis assimilis, Hodgs., from Nepal, but with shorter wings, much shorter tail, and longer and stronger hind claw.

104. Horeites brunneifrons, Hodgs.

Specimens forwarded by Père Darid from the Moupin Mountains have been thus identified by M. J. Verreaux.

105. Drymerus extensicauda, Swinh. Ibis, 1860, p. 50, 1861 , p. 32 , 1863 , p. 299 , 1865 , p. 544,1870 , p. 345 ; P. Z. S. 1863, p. 294.

Drymœpus flavirostris, Swinh. Ibis, 1863, p. 300 (young bird, individual variety).

Throughout Southern China westwards to Szechuen, in Hainan, and in Formosa. It autumn it acquires a light bill and a very long tail, the whole of its plumage being often suffused with a strong tinge of ochreous. It then much resembles D. longicauda, Tickell, of India. In spring the bill turns black, and the long tail is exchanged for a much shorter one, when it approaches the D. inornata, Sykes, of India.

106. Suya Striata, Swinh. Ibis, 1862, p. 304, 1863, p. 301.

Prinia striata, Swinh. Journ. North China Asiat. Soc. May 1859; Ibis, 1860, pp. 186, 360 .

North-west Formosa; Szechuen. Varies much in size.

107. SuYa superciliaris, Anderson, P. Z. S. 1871, anteà, p. 212.

Procured by Dr. Anderson at Momien (Yunnan Province). 
108. Rhopophilus Pekinensis, Swinh. Ibis, 1868, p. 62 ; P. Z.S. 1870 , pp. 436, 443.

Garrulax no. 175, David's Catalogue.

Pekin.

109. Cisticola schenicola, Bp.; Ibis, 1863, p. 303, 1870, p. 345 ; P. Z. S. 1863 , p. 295.

Cisticola tintinnabulans, Swinh. Ibis, 1860, pp. 51, 131.

Calamanthella tintinnabulans, Swinh. Journ. North China Asiatic Society, vol. ii. May 1859; Ibis, 1860, pp. 186, 360, 1861, p. 32.

Cisticola cursitans, Ibis, 1861 , p. 329.

Throughout China, Hainan, and Formosa.

110. Cisticola volitans, Swinh. North China Asiat. Soc. May, 1859; Ibis, 1860, pp. 186, 360, 1863, p. 304.

North Formosa.

111. Cisticola melanocephala, Anderson, P. Z. S. 1871, p. 212.

Procured by Dr. Anderson at Sonda (Yunnan).

112. Calamodyta orientalis (Temm. et Schleg.).

Calamoherpe orientalis, Swinh. Ibis, 1863, p. 305 ; P. Z. S. 1863 , p. 293,1870 , p. 427.

Acrocephalus magnirostris, Swinhoe, Ibis, 1860, p. 51, 1861, pp, 32, 329 .

Canton to Shanghai in summer. Père David notes that it passes Pekin in autumn. Mr. Wallace procured the species in Batchian, Morty, and Lombock.

113. Calamodyta fasciolatus (G. R. Gr.).

Acrocephalus fasciolatus, G. R. Gray, P. Z. S. 1860, p. 349.

Calamoherpe subfavescens, Elliot, P. Z. S. 1870, p. 243.

M. J. Verreaux received a specimen of this bird from the LakeBaikal region; and as it was impossible to suppose that it could be referred to a Moluccan species, and there was nothing else like it, Mr. D. G. Elliot described it as a new species. Lord Walden first pointed out its identity with the Batchian species. In passing to and from its summer quarters it must go through China; and so I introduce it into the China List, though it has not actually been obtained in China.

\section{Calamodyta insularis.}

Acrocephalus insularis, Wallace, Ibis, 1862, p. 350.

Calamoherpe fumigata, Swinhoe, P. Z. S. 1863, pp. 91, 293.

The close affinity of this bird to the last led me to compare it with the second Moluccan species, and I was delighted to find it the same. It comes to Amoy in May in large numbers, and disappears again almost immediately, probably into the interior of China or 
beyond. Mr. Wallace says he got $\boldsymbol{C}$. fasciolatus in Batchian, Gilolo, and Morty, and $C$. insularis in Gilolo and Morty, that they occurred sparingly, and that it always struck him that they were out of place, for, with the exception of $C$. orientalis, there was nothing like them to the east or west.

115. Calamodyta bistrigiceps, Swinh. P. Z. S. 1863, p. 293. Acrocephalus bistrigiceps, Swinh. Ibis, 1860, p. 51.

Locustella (à sourcils noirs), David, Catalogue.

Lusciniopsis, sp., Swinh. Ibis, 1861, p. 412.

Amoy ; Pekin. Allied to C. agricola, Jerd., of India, but with a black line on each side of its crown.

\section{Arundinax aëdon, Pall.}

Arundinax olivaceus, Blyth, P.Z. S. 1862, p. 316.

Turdus aëdon, Pall. Zoogr. t. i. p. 459 ; P. Z.S. 1863, p. 294, 1870, p. 432 ; Ibis, 1863 , p. 91.

Tientsin and Pekin in summer. "Comes to nidificate in our (Pekin) marshes, and leaves again in September" (David).

\section{Herbivox, n. gen.}

Bill moderate, with long lunate aperture to nostril; legs and feet large and strong, with powerful hind toe and claw ; wing rounded, with the first four quills graduated, the fourth being the longest; tail moderately graduate. A bush-loving form of Calamoherpe. I propose this genus for the three following birds, including Salicaria cantillans, T. \& S., of Japan, as they have the above characters in common, and do not range happily in any genus hitherto suggested. My Arundinax fleming $i$ is of similar form with the above, but has a square tail; this I would place in the subgenus Herbivocula.

117. Herbivox cantans.

Salicaria cantans, T. \& S. Faun. Jap. t. 19 ; Ibis, 1866, p. 397.

Procured from the interior of Formosa; not known from China.

\section{Herbivox canturiens.}

Arundinax canturiens, Swinh. Ibis, 1860, p. 52, et pp. 131, 357. Lusciniopsis canturiens, Swinh. Ibis, 1861, pp. 32, 328.

Calamoherpe canturiens, Ibis, 1863 , p. 306,1867 , p. 408,1870 , p. 345 ; P. Z. S. 1863 , p. 294.

Hainan to Shanghai, and in Formosa.

\section{1!9. Herbivox minuta.}

Arundinax minutus, Swinh. Ibis, 1860, p. 52.

Arundinax miniatus, Swinh. Ibis, 1860, p. 357.

Calamoherpe minuta, Ibis, 1863 , p. 306,1870 , p. 345 ; P. Z.S. 1863, p. 294.

Amoy ; Hainan ; Formosa.

Proc. Zool. Soc.-1871, No. XXIII. 


\section{Herbivocula flemingi.}

Arundinax flemingi, Swinh. P. Z. S. 1870, p. 440.

Salicaria cantillans, P.Z. S. 1862, p. 316, 1863, p. 294.

Tientsin (Fleming), Pekin (David). I saw two sizes of this in the Paris Museum from Pekin, but I scarcely think they are separable. There was only one specimen of each to judge from. A specimen has been received from Trans-Baikal.

121. Calamoherpe concinens, Swinh. P. Z. S. 1870, p. 432. Pekin.

\section{Calamodus sorghophilus.}

Calamodyta sorghophila, Swinh. P. Z. S. 1863, pp. 92, 293.

Amoy.

123. Dumeticola affinis, Hodgs. Cat. Specim. Brit. Mus. Mamm. \& Birds, App. p. 151.

Dumeticola thoracica, Blyth, J.A. S. xiv. p. 584.

Received at the Paris Museum through Père David from the Moupin Mountains. Has also been sent from Lake Baikal.

124. Locustella hendersonit, Cass. Proc. Phil. Acad. Sciences, 1858, p. 194 ; P. Z. S. 1863, p. 293.

Locustella rubescens?, Ibis, 1860, p. 358,1861 , pp. $32,328$.

Locustella macropus, Swinh. P. Z. S. 1863, p. 93.

China generally.

125. Locustella certhiola, Pail.

Motacilla certhiola, Pall. Zoogr. p. 509.

Pekin. The Paris Museum has specimens sent by Père David; and I have a head, also sent by him from Pekin. Trans-Baikal (Tacsanowsky).

126. Locustella rubescens, Blyth, J. A. S. xiv. p. 582.

Locustella ochotensis, Midd. Sib. Reise, t. 16, 17, 18; Ibis, 1863, p. 91 ; P. Z. S. 1863, p. 293.

Amoy. Received from Traus-Baikal. Found near Calcutta in winter (Blyth). Indian specimens have the throat and belly white, and have no yellow on the underparts, and represent the bird in the winter dress. A Baikal specimen in breeding-plumage is yellowish beneath with black spots on the breast. A specimen shot in September at Amoy is intermediate.

127. Locustella lanceolata, Temm. Man. d'Ornith. iv. p. 614 .

Locustella minuta, Swinh. P. Z. S. 1863, pp. 93, 293 ; Ibis, 1866, p. 293.

Locustella allied to L. raii, Swinh. Ibis, 1861, p. 412 . 
Amoy; Canton; Pekin (David); Lake Baikal (Tacsanowsky). Has been shot in Europe.

I have lately received from Trans-Baikal a bird of this group, which I at first thought might be Calamoherpe maackii, of $\mathrm{V}$. Schrenck; but it seems to be a novel form, and I would propose to designate it

\section{Locustella taCsanowskia, n. sp.}

Bill black, bright yellow on the basal half of the lower mandible. Legs and toes yellowish flesh-colour. Upper parts olive-brown; wing- and tail-feathers hair-brown, broadly margined with olivebrown. Underparts and slight superciliary streak yellowish, with the breast, flanks, and tibiæ washed with olive-brown. Length 5 inches ; wing $2 \cdot 2$; tail $1 \cdot 9$, much graduated, outer rectrix $\frac{6}{12}$ shortest. First primary of wing broad, $\cdot 6$ long, second $\frac{1}{2}$ inch shorter than third, which is slightly shorter than the fourth.

The nearest in form to this bird is the Locustella ochotensis, from which, however, it can readily be distinguished by its smaller size, short and blunt bill, unspotted upper parts, and light untipped tail.

The Curator of the Museum at Warsaw, M. 'Tacsanowski, sent this bird to M. Jules Verreaux, labelled Dumeticola. thoracica, juvenis. It is likely to occur as a winter visitant in China; but as it has not been yet found in that country, I do not number it in my list.

128. Tribura luteiventris, Horsf. P. Z. S. 1845, p. 30.

Calamodyta affinis, Gray \& Mitch. G. of B. pl. 49.

Sent to the Paris Museum by Père David from Moupin.

129. Tribura squamiceps, Swinhoe, P. Z. S. 1863, p. 292 ; Ibis, 1866 , p. 397.

Canton; Formosa.

130. Sylvia curruca, Linn. Fn. Suec. 247.

Curruca garrula, Bris. Av. iii. p. 384. n. 7.

Very rare at Pekin, but common at Ordo (David). Mr. Gould has a specimen from Kalgan.

131. Philacantha nisoria (Bechst.).

Nisoria undatu, P. Z. S. 18:0, p. 430.

Pekin (David).

\section{Oreopneuste davidir.}

Abrornis davidii, Milne-Edwards, Nouv. Arch. d. Mus. 1864, t. i. pl. 2. fig. 1 .

In structure this species is neither an Abrornis nor a true Phyllopneuste, and may with propriety be ranked in a separate genus in company with $P$. agricolensis, Hume, of India. In coloration it resembles my draudinax flemingi, and might at the first glance be 
mistaken for that bird. It is thus described by Milne-Edwards :" Above of an olive-brown tint ; a greyish-white eye-streak stretches from the base of the beak to the nape, and then curves towards the similar streak on the other side. Throat greyish white; breast and belly tinted on their sides with clear brown, greyish white washed with yellow towards their middle. Tarse yellowish."

Nests in the high mountains near Pekin (David).

133. Phyllopneuste fuscata (Blyth); Swinh. Ibis, 1863, p. 306,1870 , p. 345 ; P. Z. S. 1863 , p. 295.

Phylloscopus fuscatus, Blyth, J. A. S. xi. p. 113, xii. p. 965; Ibis, 1861, pp. 32, 330, 1863, p. 93.

Phyllopneuste sibirica, Midd. Sib. Reise, ii. tab. 16. figs. 4-6.

As in the case of $P$. sylvicultrix, there is certainly much variability in the size and measurements of these brown Willow-Wrens; but $I$ have not yet succeeded in discriminating them as species ( $c f$. Tristram, 'Ibis,' 1871, p. 110). I have not been able to detect any differences in the notes and habits of those I have come across. The spotted eggs taken in Formosa, alluded to by Mr. Tristram, cannot, I fear, be trusted to, their authenticity depending on the statement of a Chinaman.

134. Phyllopneuste tenellipes (Swinh.); P. Z. S. 1863, p. 295.

Phylloscopus tenellipes, Swinh. Ibis, 1860, p. 53.

Amoy; Pekin (David).

135. Phyllopneuste coronata (Temm. \& Schleg.); Ibis, 1863, p. 307 ; P. Z. S. 1863 , p. 297.

Phylloscopus coronatus, Ibis, 1860, p. 54, 1861, p. 330, 1863, p. 93 ; P. Z.S. 1862 , p. 317.

Amoy ; Pekin (David).

136. Phyllopneuste xanthodryas, Swinh. P. Z. S. 1863 , p. 296.

Amoy.

137. Phyllopneuste Plumbeitarsus, Swinh. Ibis, 1870 , p. 345 ; P. Z. S. 1863 , p. 296.

Phylloscopus plumbeitarsus, Ibis, 1861, p. 330.

A small species with short thick bill and small feet; lesser and greater wing-coverts both tipped with yellow, forming a double bar across the wing; primary quill $\cdot 6$ in. long, second one-third of an inch shorter than the third.

Pekin; Hainan.

138. Phyllopneuste borealis, Blasius, Naumannia, 1858, p. 313 ; Ibis, 1862, p. 68 .

Phylloscopus sylvicultrix, Swinh. Ibis, 1860, p. 53, 1866, pp. 135, 295, 394. 
Phyllopneuste sylvicultrix, Ibis, 1863, p. 307 ; P.Z.S.1863, p. 295. Phyllopneuste javanica, Bp. (nec Horsf. quæ Zosterops), Consp. Av. i. p. 290.

Sylvia (Phyllopneuste)eversmanni, Midd. (nec Bonap.) Sib. Reise, Vög. p. 178, t. 16. f. 1-3.

Sylvia flavescens, G. R. Gray, P. Z. S. 1860, p. 349.

Phyllopneuste kennicotti, Baird, Trans. Chicago Acad. Sci. 1869, i. p. 313 , pl. 30. fig. 2.

This Willow-Wren passes through Amoy each spring and autumn in immense numbers; and I have a large series which vary in size and length of parts, but can barely be separated into large and small races, as intermediate sizes occur. I have seen our species from the Tenasserim province, and have two skins of the same from Flores, collected by Mr. Wallace, and marked S. flavescens, G. R. Gray. Dr. V. Schrenck has sent me the same from the Kurile Islands labelled Sylvia eversmanni; and we have received many from Trans-Baikal through Madame Verdey of Paris. Further, I have examined two specimens from North Russia, collected by M. Mèves, and kindly lent me by Messrs. Salvin and Godman, to whom they belong. These are marked $P$. eversmanni, and are also identical with our China bird. Dr. Hartlaub's $P$. borealis is founded on a specimen from the shores of the sea of Okhotsk ; and on carefully reading his description of it, and comparing it with the so-called $P$. javanica (a Java specimen), I find no material difference between them, further than I can match from my series of specimens from China. Finally, Mr. Tristram insists that the type of $P$. kennicotti, Baird, from Alaska, which has been submitted to his inspection, is no other than our Chinese friend. This species thus shows itself to be a great wanderer, resorting in winter to the Malayan peninsula and archipelago, and seeking a summer home in the high latitudes of Asia, extending even to Russia (and apparently to Heligoland) on the European side, and to Alaska on the American side. During its migrations it occurs in Formosa; and I have seen it in the Leyden Museum from Japan.

139. Reguloides proregulus (Pall.), Ibis, 1867, p. 408, 1870 , p. 345 ; P. Z. S. 1863 , p. 297.

Motacilla proregulus, Pall. Zoogr. i. p. 499.

Reguloides chloronotus, Ibis, 1860, p. 54, 1861, pp. 33, 330.

China generally.

140. Reguloides superciliosus, Ibis, 1863, p. 307, 1866, p. 135,1867 , p. 408,1870 , p. 345 ; P. Z. S. 1863 , p. 297.

Motacilla superciliosa, Gmel. Syst. Nat. 1788, i. p. 975 .

Reguloides proregulus, Ibis, 1860, p. 54, 1861, pp.32, 330, 1862, pp. 257, 258.

China generally ; Formosa.

141. Abrornis fulvifacies, Swinhoe, P.Z.S. 1870, p. 132.

Szechuen province. 
142. Cryptolopha tephrocephala, Anderson, P. Z. S. 1871, p. 213.

A copy of Cryptolopha (olim Culicipeta) burkii, but with the green of the crown changed to grey. Procured at Bhamo (Burmah) by Dr. Anderson, and sent from Moupin to Paris by Père Darid.

143. Regulus Japonicus, Bp. Consp. Av.; P. Z. S. 1870, p.451. North China.

144. Regulus himalayensis, Blyth; Gould, B. of As. pt. xxi. Sent from Moupin by Père David to the Paris Museum.

145. Ruticilla aurokea (Pall.); Swinhoe, Ibis, 1860, p. 54, 1861 , pp. 33, 329, 1862, p. 261, 1863, p. 299, 1870, p. 344; P. Z. S. 1863 , p. 291,1870 , p. 438.

Phonicurus reevesii, Gray, Zool. Misc. p. 1.

Throughout China; Hainan; Formosa.

146. Ruticilla hodgsonit, Moore, P. Z. S. 18j4, pl. 58.

Procured by Père David at Moupin.

147. Ruticilla rufiventris (Vieill.).

Enanthe rufiventris, Vieill.

Ordo Mountains, N.W. of Pekin and Moupin (David).

148. Ruticilla frontalis, Vig.; Gould, Cent. pl. 26.

Sent by Père David from Moupin; Pekin (David).

149. Ruticilla fuliginosa, Vig. P.Z.S. 1831 ; Ibis, 1861, pp. 409, 410, 1863, p. 298, 1866, p. 399 ; P. Z.S. 1863, p. 291.

Saxicola leucura (?), Ibis, 1862, p. 257.

Mountain-torrents of Southern China and Formosa.

150. Chamarkornis leucocephala.

Phonicura leucocephala, Vig. P. Z. S. 1830 ; Gould, C. B. pl. 26.

Ichang gorge of the Upper Yangtsze. Sexes similar in colour; the male has a larger foot than the female.

151. Larvivora cyane (Pall.), Ibis, 1E66, p. 315.

Motacilla cyane, Pall. Itin. iii. Append. 3, i. p. 472.

Larvivora gracilis, Swinh. Ibis, 1861, pp. 262, 409, 1863, p. 92 ; P.Z. S. 1862, p. 316, 1863, p. 291.

Larvivora cyanea, Hodgs. (?); Ibis, 1860, p. 358.

China generally.

152. Larvivora sibilans, Swinh. P. Z. S. 1863, p. 292.

Larvivora —?, Ibis, 186 1, p. 34 .

Macao. 


\section{Notodela montium.}

Myiomela montium, Swinh. Ibis, 1864, p. 362, 1866, p. 392.

Formosa. Distinguishable from M. leucura, Hodgs., of the Himalayas by the underparts being coloured as the back, instead of being black.

154. IANthia CYanura (Pall.), Ibis, 1861, p. 329, 1863, pp. 91, 298 ; P.Z. S. 1862, p. 316, 1863, p. 290.

Motacilla cyanura, Pall. Itin. ii. Append. p. 709.

Lusciola cyanura, Faun. Jap. t. 21 ; Ibis, 1860, p. 131.

Nemura rufilata, Swinh. (nec Hodgs.), Ibis, 1860, p. 54.

Ianthia rufilata, Ibis, 1862, pp. 261, 264.

Throughout China, and in Formosa.

155. Tarsiger chryseus, Hodgs.; Jard. Contr. Orn. 1850, pl. 61 .

Sent to the Paris Museum by Père David from Moupin.

156. Tarsiger superciliaris, Hodgs.; Jard. Contr. Orn. 1849, pl. 29.

Sent to Paris with the last.

157. Hodgsonius phonicuroides, Hodgs. J. A. S. xvi. p. 136.

Callene zonura, J. Verr. Nouv. Arch. 1869, Bull. p. 35.

Received at Paris through Père David from Moupin.

158. Erithacus akahige (Temm.).

In the Museum at Pekin, collected by Père David.

1j9. Copsychus saularis (L.); Zool. 1858, p. 6228 (Gryllivora); Ibis, 1860 , p. 54, 1867 , p. 409, 1870, p. 343 ; P. Z S. 1863 , p. 291.

Gracula saularis, Gmel. Syst. Nat. 1788, i. p. 397.

Southern China westwards to Szechuen, and in Hainan.

160. Kittacincla macrura, var. minor, Swinh. Ibis, 1870, p. 344 .

Hainan.

161. Cyanecula Cerulecula (Pall.); Ibis, 1863, p. 91 ; P. Z. S. 1863, p. 291.

Cyanecula suecica, Ibis, 1861 , p. 329 , 1867, p. 394 ; P.Z.S. 1862 , p. 316 .

China generally.

162. Calliope Cantschatkensis (Gin.); Ibis, $186 \mathrm{I}$, pp. 329 , 410 , 1863 , p. 299 ; P. Z.S. 1862 , p. $316,1863,292$.

China generally. 
163. Grandala celicolor, Hodgs.; G. R. Gr. \& M. Gen. of B. pl. 50.

Sent to Paris from Moupin by Père David.

164. Saxicola leucomela, Pall. Zoogr. t. 28.

Mountains west of Pekin (David).

165. Saxicola isabellina, Rüpp. Atl. t. 34.

Saxicola saltutrix, Ménétriés.

Inhabits the high plains near Pekin, sings admirably, nests in the deserted holes of Spermolegus mongolicus (David).

166. SAXicola ENANTHE, L.

Central mountains of extreme Ordo (north-west of Pekin), where it breeds (David).

167. Pratincola indica, Blyth, J. A. S. xvi. p. 129 ; Swinh. Ibis, 1860 , p. 54,1861 , pp. $33,329,1863$, p. 298,1870 , p. 344 ; P. Z. S. 1862 , p. 317,1863 , p. 291.

China generally, Hainan, and Formosa. Distinguishable at all ages from $P$. rubicola by its black axillaries and unspotted uropygials. Chinese specimens are more rust-coloured on the upper parts, and especially on the rump, than Indian ones.

168. Pratincola ferrea, Hodgs. Ibis, 1862 , p. 258 ; P. Z. S. 1863 , p. 291.

Ruticilla, sp. nov. ?, Ibis, 1861, p. 33.

South China.

169. Accentor erythropygius, Swinh. P. Z. S. 1870, p. 124, pl. 9 , \& p. 447 .

Accentor alpinus, Midd. Sib. Reise, Vögel, p. 173.

Western Hills of Pekin in September. Middendorff met with young birds on the cliffs of the south shore of the Sea of Okhotsk in July. Young birds have also been received from the TransBaikal region.

170. Accentor nipalensis, Hodgs.

Sent by Père David from Moupin. Has also been received from the Trans-Baikal.

171. Accentor multistriatus, David, Ann. Mag. Nat. Hist, April 1871.

Procured by Père David at Moupin. Closely allied to A. strophiatus, Hodgs., of the Himalayas.

172. Accentor immaculatus, Hodgs.

Sent by Père David from Moupin. 
173. Accentor montanellus (Pall.).

Accentor temminckii, Brandt.

Comes to Pekin with the great cold (David). Sent in summer plumage from the Trans-Baikal.

174. Accentor rubidus, Temm. \& Schleg. F. J. t. 32.

Père David saw the head of a bird procured at Pekin, which he identified with that of $A$. modularis, $\mathrm{L}$.

175. Parus minor, Temm. \& Schleg. F. J.t. 33 ; Swinh. Zool. 1858 , p. 6229 ; Ibis, 1860 , p. 55 et p. 131 , 1861, p. 332,1862 , p. 2.77 ; P. Z. S. 1870 , p. 437.

Amoy to Pekin, and westwards to Szechuen.

176. Parus casius, Tickell.

Parus cinereus, Ibis, 1870, p. 348.

Hainan. Our specimens agree with those from India. The Java bird, $P$. cinereus, Vieill. ( $P$. atriceps, Horsf.), can be readily distinguished by the black of the head extending beyond the white nuchal spot, and separating it from the grey of the back.

177. Parus сомmixtus, Swinh. Ibis, 1868, p. 63.

Parus minor, Ibis, 1861 , p. 34 ; P. Z.S. 1863, p. 270.

Like $P$. cresius, but with some of the green tint on the back that marks $\boldsymbol{P}$. minor, in fact intermediate to the two species. Canton to Foochow.

178. Parus monticola, Vig.; Gould, C. B. pl. 29.

Sent by Père David from Moupin to the Paris Museum.

179. Parus insperatus, Swinh. Ibis, 1866, p. 308.

South Formosa. A smaller race than the last, with the white on the tips of the tertiary quills confined to their tips, and not extending to their margins; barely separable.

180. Parus venustulus, Swinhoe, P. Z. S. 1870, p. 133.

Ichang Gorge, on the Upper Yaugtsze.

181. Parus Castaneiventris, Gould, P. Z. S. 1862 , p. 280 ; B. of As. pl.; Ibis, 1863, p. 295.

North Formosa.

182. Parus pekinensis, David; Ibis, 1870 , p. 155.

Pekin. Very like Parus ater, L., but with a few of the black coronal feathers lengthened and showing conspicuously over the white nuchal spot. 
183. Pecile kamtschatiensis, B .

Parus palustris, Ibis, 1861 , p. 331 .

Parus kamtschatkensis, P. Z. S. 1863, p. 270, 1870, p. 437.

Resident at Pekin (David). Among specimens of this species received from Trans-Baikal through M. Tacsanowsky is a very interesting form of Marsh-Tit, remarkable for its resemblance to the American P. carolinensis. This I have named P. baicalensis (Ann. \& Mag. Nat. Hist. April 1871).

\section{Pacile cincta (Bodd.).}

Parus sibiricus, Gm.

Woody mountains west of Pekin (David). From Moupin Père David has sent to Paris a handsome Machlolophus, which has not yet been described.

\subsection{Orites glaucogularis (Gould).}

Mecistura swinhoii, v. Pelzeln, Reise v. d. Novara, t. 3.

Mecistura caudata, P. Z. S. 1863, p. 270.

Parus trivirgatus, Ibis, 1860, p. 131.

Ningpo to Pekin, and westwards to Ichang.

186. Orites ouratensis, David, M. S.; Swinhoe, P. Z. S. 1870, p. 430.

A species of Orites with red eyelids was in the Pekin Museum, and has been sent to Paris. It was found by Père David in the mountains west of Pekin. It has not yet been described.

187. Egithaliscus concinnus.

Agithaliscus anophrys, Swinh. Ibis, 1868, p. 64.

Psaltria concinna, Gould, B. of Asia, pt. vii.

Fokien and Chekiang Provinces, and westward to Szechuen.

188. Egithaliscus fuliginosus.

Mecistura fuliginosa, J. Verr. Nouvelles Arch. du Muséum, t. viii. Bulletin, p. 36 .

"General colour dusky brown, forming a brown band on the breast ; face and throat silvery grey; a half collar on the anterior part of the neck and middle of the abdomen, pure white on the first, and taking a rosy tint on the flanks; wings and tail brown, the latter white on the external barbs of the four lateral quills." (J. Verreaux.)

Sent by Père David from Moupin.

189. Egithalus consobrinus, Swinh. P. Z. S. 1870, p. 133.

Egithalus pendulinus, Radde, Reisen, Band ii. p. 195.

Procured at Sha-se, near Ichang (Hoopih). Radde found it breeding in Amoorland.

190. Sylviparus modestus, Burton, P. Z. S. 1835, p. 154.

Sent from Moupin by Père David. 
191. Motacilla alboides, Hodgs., var. 1. Felix.

Motacilla luzoniensis, Ibis, 1860, pp.55, 429, 1861, p. 35, 1862, p. 259,1863 , p. 308 ; P. Z.S. 1863 , p. 274.

Motacilla felix, Swinh. P.Z.S. 1870, p. 121, fig. 1.

Like the Indian black-backed M. alboides (leucopsis, Gould, luzoniensis, auct.), but with the pectoral black, in summer plumage, advancing higher, to within half an inch of the lower mandible. Southern China and Formosa.

Var. 2. sechuenensis, Swinh. P. Z. S. 1870, p. 122, fig. 2.

The pectoral black in summer reaching to the lower mandible.

Szechuen (W. China).

192. Motacilla Parafoxa, v. Schrenck, Amurland, Vög. p. 341 , t. xi. fig. 2.

The pectoral black forming a large round patch on the breast.

Mongolia. Forwarded to Paris by Père David. p. 49.

193. Motacilla hodgsoni, G. R. Gray; Blyth, Ibis, 1865,

Motacilla francisci, Swinh. P. Z. S. 1870 , p. 123 ; Ibis, 1870 , p. 345 .

Like M.personata, Gould, of India, but with the back black instead of grey.

Hainan; Szechuen, extending to Nepal.

194. Mutacilla frontata, Swinh. P. Z.S. 1870, p. 129.

Motacilla, sp.?, Ibis, 1867 , p. 390 .

Amoy in winter.

\section{Motacilla baicalensis, $n$. sp.}

Motacilla dukhunensis (?), P. Z. S. 1870, p. 130.

The representative in Eastern Asia of M. alba, L., of Europe ; with clearer plumage, smaller bill, wing of a lighter brown, with much more white, especially on the wing-coverts. In full summer plumage the pectoral black contracts on the throat, and falls short of the chin. It has a very close ally in M. dukhunensis, Sykes, of India, but may be distinguished from that by its larger bill, greater amount of white on the wing-coverts; and in nuptial dress by the form of the pectoral paich. Occasional specimens from Trans-Baikal have a black line uniting the back of the eye with the black of the nape, but otherwise similar to the typical bird. This I would propose to distinguish as var. temporalis. It will probably be the bird procured in Lombardy in the collection of Count Turati of Milan (see Baron de Selys-Longchamps in Ibis, 1870, p. 451). Numerous skins of the Baikal Wagtail have been received through Madame Verdey of Paris; and it is doubtless the species observed by me on the Upper Yangtsze (P.Z. S. 1870, p. 130). 
196. Motacilla ocularis, Swinh. Ibis, 1863, pp. 94, 309; P. Z. S. 1863 , pp. 275 , 1870 , p. 130, fig. 346 .

Motacilla lugubris, Ibis, 1860 , p. 55, 1861, pp. 35, 255, 333, 1862 , p. 260 ; P. Z. S. 1862 , p. 317.

Distinguishable in all plumages by the dark streak through its ere and its grey back.

China, Hainan, and Formosa. Specimens have also been received from Trans-Baikal.

197. Motacilla Japonica, Swinh. P. Z. S. 1863, pp. 17, 274, 1870 , p. 130.

Motacilla lugens, Temm. (nec Illig.) ; Ibis, 1860, p. 357.

Motacilla lugubris, Ibis, 1862 , p. 260, 1863, p. 308.

Motacilla alba, var. from Kamtschatka, Pall. Zoograph.

Distinguishable from the last in winter by its larger size, its whiter wing, and black-marked back. This is the species that announces the returu of spring to the Kamtschatkans (Kittlitz). M. lugubris, Pall. \& Temm. (lugens, llliger), is the M. vidua, Sundevall, of Africa (see Tristram, 'Ibis,' 1866, p. 291).

198. Budytes flavus (L.); Swinh. Ibis, 1860, p. 55, 186I, pp. 36, 333, 411, 1862, p. 260 ; P. Z. S. 1863 , p. 274.

Budytes flavescens, G. R. Gray, P. Z. S. 1860, p. 350.

China generally. Mr. Wallace has bright-plumaged birds from the Moluceas which also agree with the European species; and $\mathrm{Mr}$. Baird reports it from Alaska.

199. Budytes taivanus, Swinh. Ibis, 1870 , p. 346, 1866 , p. 138.

Budytes rayi?, Ibis, 1862, p. 260, 1863, p. 309.

Budytes melanotis, Ibis, 1864, p. 422.

Amoy; Formosa; Hainan. I have a specimen also from TransBaikal ; and Mr. Gould has one from Singapore.

200. Budytes Cinereocapillus, Sav.; Ibis, 1863, p. 94, 1870, p. 346 ; P. Z. S. 1862 , p. 317 .

Occurs singly or in pairs throughout China in spring.

201. Budytes citreolus (Pall.).

Szechuen. I came across a party of this Wagtail on the Upper Yangtsze in May.

202. Calobates melanope.

Motacilla melanope, Pall. Itin. iii. p. 696. n. 16 ; Zoogr. i. p. 500. Motacilla bistrigata, Raffles, Trans. Linn. Soc. xiii. part 2, p. 312. Motacilla boarula, Ibis, 1860 , p. 55, 1861, pp. 35, 333, 1862, p. 260,1863 , p. 309,1866 , p. $138 ;$ P. Z. S. $186^{\circ}$, p. 317,1863 , p. 274 .

Calobates boarula, Ibis, 1870, p. 346. 
China; Formosa; Hainan. Like C. boarula, but with a constantly shorter tail.

203. Limonidromus indicus (Gmel.); Gould, B. of As. pt. xiv. Nemoricola indica, Ibis, 1861 , p. 333,1863 , p. 94 ; P. Z. S. 1862, p. 317,1863 , p. 276,1870 , p. 433.

Pekin and Szechuen.

204. Henicurus sinensis, Gould, P. Z. S. 1865, p. 665 ; Ibis, 1867, p. 404.

Henicurus chinensis, Gould, B. of As. pt. xviii.

Henicurus leschenaultii, P. Z. S. 1863, p. 276.

Enicurus speciosus, Ibis, 1861, p. 265, 1862, pp. 261, 264.

Fokien province.

205. Henicurus leucoschistus, Swinh. Ann. \& Mag. N. H. vol. vi. 4 th series, p. 154 .

Enicurus schistaceus, Ibis, 1861, pp. 409, 410 ; P. Z. S. 1863, p. 276 .

Fokien; Moupin (David). Like H. schistaceus, Hodgs., of Nepal, but wants the white tips that mark the first to the sixth primaries of the Indian bird, and its under wing instead of having the bases of the primary quills white, commencing from the second quill and increasing inwards, has the basal third of the quills edged on their inner webs with white, commencing from the fourth quill inclusive.

206. Henicurus scouleri, Vig.; Gould, B. of Asia, pt. xviii.

Moupin (David).

207. Anthus spinoletta, L.

Anthus aquaticus, Bechst.

Anthus blakistoni, Swinh. P. Z. S. 1863, pp. 90, 273 ; Ibis, 1867, p. 389.

Amoy; river Yangtsze. I have seen a specimen of the true $A$. obscurus, Gmel., from India.

208. Anthus Cervinus, Pall. Zoograph. i. p. 511 ; Ibis, 1870 , p. 347 ; P. Z. S. 1863 , p. 273.

Anthus thermophilus, Ibis, 1860, pp. 55, 429, 1861, pp. 36, 411, 1863 , p. 311.

Anthus japonicus, Ibis, 1861, p. 333.

Throughout China; Hainan ; Formosa. It is a mistake to identify the European A. cecilii, Audouin (=A.rufogularis, Brehm), with our eastern $A$. cervinus. Ours is a smaller bird, with shorter wing, and in summer is easily distinguished by the rosy hue of its eyebrow and breast, which in the other are rust-colour, the breast being streaked with black. The streaks on the flanks, too, in the latter are much longer and broader. 
209. Anthus rosaceus, Hodgs.

Sent from Moupin by Père David.

210. Pipastes agilis (Sykes); Gould, B. of As. pt. xvii.; Ibis, 1870 , p. 347.

Anthus agilis, Ibis, 1860 , p. 55, 1861, pp. 36,333 , 1863, p. 310 ; P. Z. S. 1863, p. 273.

Throughout China; Hainan; Formosa.

\section{Corydalla gustavi.}

Anthus gustavi, Swinh. P. Z. S. 1863, pp. 90, 273.

Anthus batchianensis, G. R. Gray, Hand-list, p. 251.

Comes to Amoy in spring in large numbers; but whither it goes I cannot tell. Mr. Wallace procured the same species in Batchian.

212. Corydalla richardi (Vieill.), Pl. Col. 101; Ibis, 1870, p. 347 .

Anthus richardi, Ibis, 1860 , p. 55,1861, pp. $36,333,1863$, p. 311,1865 , p. 234 ; P. Z. S. 1862 , p. 317 , 1863, p. 272.

Corydalla infuscata, Blyth. (Race that breeds on the Fokien Hills.)

Corydalla sinensis, Ibis, 1861, p. 265.

Throughout China; Hainan. Rare in Formosa.

213. Corydalla chinensis, Bp. Consp. Av. i. p. 525.

A smaller and more ochreous race than the last. Amoy in spring.

214. Turdus naumannt, Temm. Man. d'Orn. i. p. 170 ; Ibis, 1863, p. 277 ; P. Z. S. 1863 , p. 280.

Shanghai to Pekin, and westwards to Szechuen.

215. Turdes fuscatus, Pall. Zoogr. i. p. 451 ; Ibis, 1863 , pp. 93, 277; P. Z. S. 1862, p. 317, 1863, p. 280.

Amoy to Pekin, and in Formosa ; westwards to Szechuen.

216. Turdus musicus, L.

Foochow (Gould), Pekin (David). I have compared this bird, in company with Mr. Gould, with other specimens of the species. The Chinese bird does show some differences from home-shot examples, but a bird from Malta differs still more.

217. Turdus ruficollis, Pall. It. iii. p. 694 ; Gmel. Syst. Nat. 1788, p. 815 ; P. Z. S. 1863 , p. 281.

Turdus — ?, Ibis, 1861, p. 332.

Pekin ; Moupin (David).

218. Turdus Pallidus, Gmel. Syst. Nat. 1788, p. 815 ; Pl. Col. 515; Ibis, 1863, p. 276.

Turdus daulias, Temm. Faun. Japon. t. 26 ; Ibis, 1860, p. 56, 1861 , p. 57,1862 , p. 261 ; P. Z. S. 1863 , p. 280. 
Turdus advena, Swinh. Ibis, 1860, pp. 56, 358.

Amoy to Peking; Formosa.

219. Turdus chrysolaus, Temm. Pl. Col. 537 ; Ibis, 1860, p. 56,1863 , p. 276,1870 , p. 248 ; P. Z. S. 1863 , p. 280.

Hainan to Pekin ; Formosa.

220. Turdus obscurus, Gmel. Syst. Nat. 1788, p. 816 ; Ibis, 1863, p. 277.

Turdus pallens, Pall.; Ibis, 1860, p. 56, 1861, p. 37, 1863, p. 93 ; P. Z. S. 1862 , p. 317,1863 , p. 280.

Turdus rufulus, Drap.

Turdus modestus, Eyton.

Turdus pallidus, Ibis, 1861, p. 332.

Turdus davidianus, Milne-Edwards, Nouv. Arch. i. Bull. p. 26.

Malacca to Pekin, and westwards to Szechuen; Formosa. To be at once distinguished from the last by its conspicuous white eyebrow.

221. Turdus hortulorum, Sclater, Ibis, 1863, p. 196 ; P. Z. S. 1863 , p. 280.

Turdus — ? Ibis, 1861, p. 37.

South China.

222. Turdus albiceps, Swinh. Ibis, 1864, p. 363 , 1866, p. 135, pl. 5, \& p. 315 .

Formosa.

223. Turdus cardis, Temm. Pl. Col. 518 ; Ibis, 1860, p. 132, 1861 , p. 37,1870 , p. 248 ; P. Z. S. 1863 , p. 280.

South China in winter.

224. Turdus sibiricus, Pall. It. iii. p. 694; Syst. Nat. 1788, p. 815 ; Ibis, 1861 , p. 410 , 1863, p. 93 ; P. Z. S. 1862 , p. 317 , 1863 , p. 279.

Geocichla, n. sp., Ibis, 1861, p. 37.

A winter straggler in China generally.

225. Merula sinensis (Cuv.); G. R. Gray, Hand-list of B. i. p. 255 ; Zool. 1858 , p. 6228 .

Turdus mandarinus, Bp.; Ibis, 1860, p. 56, 1861, p. 38,1870 , p. 248 ; P. Z. S. 1863 , p. 281.

Hainan to Shanghai, and westwards to Szechuen. A fine chestnut-coloured species, allied to $M$. castanea (Gould) of India, has been sent to Paris by Père David from Moupin.

226. Oreocincla varia (Pall.).

Turdus varius, Pall. Zoogr. i. p. 449.

Oreocincla aurea, Bp.; Ibis, 1860, p. 56 ; P. Z.S. 1863, p. 278. 
Oreocincla hancii, Swinh. Ibis, 1863, p. 275, 1866, p. 304.

Oreocincla whitei, Ibis, 1861, p. 333.

China generally, and in Formosa.

227. Oreocincla mollissima.

Turdus mollissimus, Blyth, J. A. S. xi. p. 185.

Sent by Père David from Moupin.

228. Monticola saxatilis, L.

Summers on the Pekin Mountains (David).

229. Petrophila gularis.

Orcecetes gularis, Swinh. Ibis, 1863, p. 93, pl. 3 ; P. Z. S. 1862 , p. 318,1863 , p. 282.

Monticola — ?, Ibis, 1861, p. 332.

Breeds on the Pekin Mountains (David).

230. Petrocincla manilla (Bodd.); Ibis, 1870, p. 248.

Petrocincla violacea, Swinh. Zool. 1858, p. 6228.

Petrocincla manillensis, Ibis, 1863, p. 274, 1866, p. 136, 1867, pp. 233, 404 ; P. Z. S. 1862, p. 317, 1863, p. 281.

Petrocossyphus manillensis, Ibis, 1860, pp. 56, 429, 1861, p. 38 , 1862, p. 307,1863 , p. 93.

Hainan to Tientsin, and in Formosa.

231. Petrocincla cyanea (L.).

Interior of China. Common in the gorges of the Upper Yangtsze. Rare at Amoy and on the Chinese coast.

232. Petrocincla affinis, Blyth, J. A. S. xii. p. 177.

Smaller than $P$. manilla, with the vent and belly more or less red; intermediate between $P$. manilla and $P$. cyanea. The common form on the South-China coast.

233. Myiophoneus Caruleus (Scop.); Ibis, 1861, p. 36, 1862, pp. 262, 264 ; P. Z. S. 1863, p. 277.

Myiophoneus horsfieldii, Vigors?; Ibis, 1860, p. 55.

Turdus violaceus, Gmel. Syst. Nat. 1788, p. 826.

Turdus nitidus, Gray, Zool. Misc. p. 1.

South China, westwards to Szechuen.

234. Myiophoneus insularis, Gould, P. Z. S. 1862, p. 180 ; B. of As. pl. ; Ibis, 1863, p. 577 .

Formosa.

235. Hydrobata Pallasi, Temm. Man. d'Ornith. iii.p. 107.

Cinclus pallasi, Ibis, 1863 , p. 272 ; P. Z. S. 1863 , p. 277 . 
H. marila, Swinh. North China Asiat. Soc. Journ. May 1859; Ibis, 1860, pp. 187, 360 .

Formosa, Ichang gorge of the Upper Yangtsze.

236. Hypsipetes leucocephalus.

Turdus leucocephalus, Gmel. Syst. Nat. 1788, p. 826.

T. melaleucus, Gray, Zool. Misc. p. 1 .

H. niveiceps, Swinh. Ibis, 1864, p. 424, 1865, p. 107.

South China to Szechuen.

237. Hypsipetes nigerrimus, Gould, P. Z. S. 1862 , p. 282 ; B. of As. pt. xvi.; Ibis, 1863, p. 287.

Forinosa. fig. 2 .

238. Hypsipetes Pernigre, Swinh. Ibis, 1870, p. 251 , pl. 9.

Hainan.

239. Hypsipetes yunanensis, Anderson, P. Z. S. 1871, anted, p. 213.

Procured by Dr. Anderson at Ponsee (Yunnan province).

240. Hypsipetes maCClellandi, Horsf. P. Z. S. 1839, p. 159.

H. holti, Swinhoe, Ibis, 1S61, pp. 266, 409 ; P. Z. S. 1863 , p. 277.

Fokien province.

241. Hemixus castanonotus, Swinh. Ibis, 1870, p. 251, pl. 9. fig. 1.

\section{Hainan.}

242. Ixus Sinensis, Ibis, 1863, p. 289 ; P. Z. S. 1863 , p. 278.

Muscicapa sinensis, Gmel. Syst. Nat. 1788, i. p. 942.

Pycnonotus sinensis, Ibis, 1860, p. 57.

P. occipitalis, Ibis, 1861 , p. 39.

Luichow to Shanghai, and westward to Szechuen, also in Formosa. Shanghai samples are larger, with the black of the crown somewhat obscuring the white of the occiput; Szechuen specimens have the occiput very white, with a pale halter mark round the neck; but both these varieties occasionally occur at Amoy.

243. Ixus hainanus, Swinh. Ibis, 1870, p. 253.

Like the last, but with the occiput, as well as the crown, black.

Hainan.

244. IXUS XaNthorrhous.

Pycnonotus xanthorrhous, Anderson, Proc. Asiat. Soc. Beng. 1869, p. 265.

Proc. Zool. Soc.-1871, No. XXIV. 
Ixus andersoni, Swinh. Ann. \& Mag. Nat. Hist. vol. v. 4th series, p. 175.

Ichang gorge of the Upper Yangtsze. Obtained also by Dr. Anderson at Momien (province Yunnan), and by Père David in Kokonor.

245. Ixus Chrysorrhoides (Lafr.); Ibis, 1867, p. 232, 1868, p. 63 ; P. Z. S. 1863 , p. 278.

Hamatornis chrysorrhoides, Lafr. Rev. Zool. 1845, p. 367.

Pycnonotus hamorrhous, Ibis, 1860, p. 57.

Muscicapa atricapilla, Vieill.; Ibis, 1860, p. 358.

Pycnonotus chrysorrhoides, Ibis, 1861, p. 39.

Ixus hamorrhous, Ibis, 1862, p. 307.

South China.

246. Ixus Jocosus (L.) ; P. Z.S. 1863, p. 277.

Pycnonotus jocosus (L.) ; Ibis, 1861, p. 39.

Canton.

247. Spizixus Semitorques, Swinh. Ibis, 1861 , p. 266 ; P. Z. S. 1863 , p. 278.

Fokien province, and westwards in the Ichang gorge.

248. Spizixus Cinereicapillus, n. sp.

Sp. semitorques, Swinh. Ibis, 1863, p. 290.

I identified the Formosan bird with the China species from a specimen injured about the head. The acquisition of a series from the Formosan mountains establishes the distinction between the two. The Formosan race is like the China bird, but has the dark parts of the head grey instead of black.

249. Criniger Pallidus, Swinh. Ibis, 1870, p. 252.

Hainan.

250. Phyllornis lazulina, Swinh. Ibis, 1870, p. 255.

Hainan.

251. Sibia auricularis (Swinh.); Sclater, Ibis, 1866, p. 109, pl. 4 , p. 401.

Kittacincla auricularis, Swinh. Ibis, 1864, p. 361.

Formosa.

252. Pomatorhinus erythrocnemis, Gould, P. Z. S. 1862 , p. 281 ; B. of As. pl.; Ibis, 1863, p. 286.

Formosa.

253. Pomatorhinus musicus, Swinh. North China Asiat. Soc. Journ. May 1859 ; Ibis, 1860, pp. 187, 360, 1861, p. 284, pl. 6.

Formosa. 
254. Pomatorhinus stridulus, Swinh. Ibis, 1861, p. 265 ; P. Z. S. 1863 , p. 278.

South China, westwards to Szechuen.

255. Pomatorhinus nigro-stellatus, Swinh. Ibis, 1870 , p. 250.

\section{Hainan.}

256. Pterorhinus davidi, Swinh. Ibis, 1868 , p. 61.

Western mountains of Pekin; a fine songster. Two other species of this genus have been received from Moupin at Paris; they will be described by M. J. Verreaux.

257. Leucodioptrum ChINENSE.

Turdus chinensis, Osb. Itin. 309.

Turdus sinensis, Gmel. Syst. Nat. 1788, p. 826.

Garrulax canorus, Ibis, 1860, p. 358, 186 I, p. 38.

Leucodioptrum sinense, Ibis, 1870, p. 250 ; P.Z. S. 1863, p. 278.

Hainan to Ningpo.

258. Leucodioptrum taivanum.

Garrulax taëwanus, Swinh. Journ. North China Asiat. Soc. May 1859, no. 2, p. 228 ; Ibis, 1860 , pp. 187, 360, 1863, p. 279.

Malacocercus taivanus, Ibis, 1865 , p. 546.

Formosa.

259. Garrulax chinensis (Scop.); Sonn. Voy. t. 107 ; Ibis, 1864, p. 423.

Turdus shanhu, Gmel. Syst. Nat. 1788, p. 814 .

Garrulax auritus (Daudin); Ibis, 1865, p. 350.

South-west Kwangtung.

260. Garrulax perspicillatus (Gmel.); Pl. En. 604 ; Ibis, 1861 , p. 38,1862 , p. 306 ; P. Z. S. 1863 , p. 278.

Garrulax rugillatus, Swinh. Ibis, 1860, pp. 57, 358.

Turdus perspicillatus, Gmel. Syst. Nat. 1788, i. p. 830.

Canton to Ningpo, and westward to Szechuen.

261. Garrulax albogularis (Gould, P. Z. S. 1835, p. 187).

Sent from Moupin by Père David.

262. GarRulax RUficeps, Gould, P. Z. S. 1862, p. 281 ; B. of As. pl. ; Ibis, 1863, p. 282.

Formosa. Like the last, but with a rufous cap.

263. Garrulax sannio, Swinh. Ibis, 1867, p. 403.

South China, and westwards to Szechuen. Procured in Western Yunnan by Dr. Anderson. 
264. Garrulax monachus, Swinh. Ibis, 1870, p. 248.

Hainan.

265. Ianthocincla pecilorhyncha (Gould).

Garrulax pacilorhynchus, Gould, P. Z. S. 1862, p. 281 ; B. of As. pl. ; Ibis, 1863, p. 283, 1866, p. 303.

Formosa.

266. Cinclosoma artemisiz, David, Ann. \& Mag. Nat. Hist. April 1871, p. 256.

Allied to C. ocellatum, Vigors, of the Himalayas. Procured by Père David at Moupin, Western Szechuen.

267. Trochalopterum formosum, J. Verr. Nouv. Arch. 1869, Bull. p. 35 .

"General tint olivaceous rust-colour ; head grey, lanceolated with black; throat and front of neck of this last colour; a great portion of the wings and of the upper surface of the tail blood-red. Belly and abdomen olivaceous." - J. Verreaux.

Sent by Père David from Moupin. Two other species of this genus, also from Moupin, remain to be described.

268. Conostoma жmodium, Hodgs. J. A. S. x. p. 856.

Sent from Moupin by Père David.

269. Paradoxornis flavirostris, Gould, P. Z. S. 1836, p. 17. Sent from Moupin by Père David.

270. Heteromorpha unicolor, Hodgs. J. A. S. xii. p. 448.

Sent from Moupin by Père David. Like this in coloration is a curious species, also from Moupin, with one of its toes rudimentary.

271. Suthora bulomachus, Swinh. Ibis, 1866, pp. 299, 303, pl. 9.

The lower hills of Formosa.

272. Suthora suffusa, n. sp.

A smaller conspecies of the last, with the hind neck of a richer rufous and more definitely separated from the greyish olive of the back. Back washed with rufous in the other, blending with the rufous of the head. Bill smaller. Legs and feet much smaller; wing 2 inches, tail $2 \cdot 5$.

Seen in small parties in spring about the mountainous sides of the gorges on the Upper Yangtsze.

273. Suthora webbiana, G. R. Gray, P. Z. S. 1852 , p. 70 ; Gould, B. of As. pl.; P. Z. S. 1863, p. 271.

Abundant about the hedges near Ningpo and Shanghai ; mountains of Pekin (David). Kept in Shanghai for its fighting-qualities. 
Like its Formosan congener it is very pugnacious, and will fight its fellows to the death. The Chinese use it in the gambling-ring.

274. Suthora gularis, J. Verr. Nouv. Arch. 1869, Bulletin, p. 35.

"Couleur générale laque jaune, derenant blanche sur les joues et le milieu de la partie inférieure excepté la gorge, qui est d'un noir pur; rémiges et rectrices noirâtres; partie supérieure de ces dernières rougeâtres, une tache jaune mordorée sur le milieu de l'aile s'étendant sur une partie des secondaires." -J. Verreaux.

Sent by Père David from Moupin. Père David has also sent another species hitherto undescribed from the same locality.

275. Suthora brunnea, Anderson, P. Z. S. 1870, anteà, p. 211.

Procured by Dr. Anderson at Momien (Yunnan province).

276. Leiothrix lutea (Scop.); Ibis, 1865, p. 349 ; P. Z. S. 1863, p. 298.

South-west China, whence brought to Canton and sold alive in bird-shops.

Père David has sent a new Minla from Moupin, allied to $M$. ignitincta, Hodgs., of the Himalayas.

277. Yuhina nigrimentum, Hodgs. J. A. S. xiv. p. 562.

Sent by Père David from Moupin.

278. Yuhina diademata, J. Verr. Nouv. Arch. 1869, Bull. p. 35 .

" Couleur générale brun terreux, plus pâle en dessus ; milieu de l'abdomen, les couvertures sous-caudales blanc pur, devenant d'une teinte encore plus pure sur la grande tache occipitale, qui est précédée par de longues plumes formant une huppe; ailes et queue noires avec les rachis d'un blanc plus visible sur la dernière, qui est échancrée."-J. Verreaux.

Sent by Père David from Moupin.

279. Stachyris Precognitus, Swinh. Ibis, 1866, p. 310 .

Very like St. ruficeps, Blyth, of Nepal, but smaller, with much smaller bill, and with the red of the head confined to the crown.

Formosa ; Ichang gorge of the Yangtsze river.

280. Herpornis tyrannulus, Swinh. Ibis, 1870, p. 347 , pl. 10.

Herpornis xanthochlora, Swinh. Ibis, 1863, p. 293.

Herpornis xantholeuca, Swinh. Ibis, 1866, p. 394.

Formosa ; Hainan.

281. Staphida torqueola.

Siva torqueola, Swiuh. Ann. \& Mag. Nat. Hist. vol. v. 4th series, p. 174 . 
I described this as a Siva; but it is more allied to the genus Ixulus, from which it differs in having a deeply graduated tail. Ixulus castaneiceps, Moore, is of the same form as our bird; and I would propose to place these two under a new subgenus, Staphida. Our species was procured in Fokien province. Père David has sent a new species of Ixulus from Moupin.

282. Alcippe nipalensis.

Sent from Moupin by Père David.

283. Alcippe morrisonia, Swinh. Ibis, 1863, p. 296, 1865, p. 107.

Formosa. A smaller conspecies of the last.

284. Alcippe brunnea, Gould, P. Z. S. 1862, p. 280, B. of As. pl. ; Ibis, 1863, p. 297.

Formosa.

285. СосноA viridis, Hodgs. J. A. S. v. p. 359 ; Ibis, 1868, p. 354 .

A single specimen procured at Amoy in December 1867. The Paris Museum has received the bird from Cochin-China.

286. Ampelis garrula (L.); P. Z. S. 1863, p. 298.

North China.

287. Ampelis phanicoptera, Temm. F. J.; Ibis, 180̈4, p. 427, 1866, p. 307 .

North China; Formosa.

288. Psaropholus ardens, Swinh. Ibis, 1862, p. 363, 1863, p. 293,1866 , pp. 297,398 .

Formosa.

289. Psaropholus ardens, var. Nigellicauda, Swinh. Ibis, 1870 , p. 342.

Hainan.

290. Oriolus chinensis, Gmel. Syst. Nat. 1788, p. 383 ; Swinh. Ibis, 1860 , p. 57,1861 , pp. $58,341,1863$, p. 291,1866 , p. 138, 1870, p. 342 ; P. Z. S. 1863, p. 282.

Oriolus cochinensis, Briss. Av. ii. p. 326.

Oriolus indicus, Jerd. Ill. Ind. Orn. pl.

Throughout China, and Formosa in summer. Resorts in winter to Cochin-China, Tenasserim, and India.

291. Pitta moluccensis (Müll.).

Turdus moluccensis, P. L. S. Müller, Natursyst. Anhang (1766), p. 144.

Pitta cyanoptera, Temm. 
Pitta nympha, Swinh. Ibis, 1861, pp. 412, 414; P. Z. S. 1863, p. 277.

A single specimen procured at Amov.

292. Pitta oreas, Swinh. Ibis, 1864, p. 428.

Formosa.

293. Lanius Lahtoka (Sykes, P. Z. S. 1832, p. 86); Sharpe and Dresser, P. Z.S. 1870, p. 595.

Pekin in winter (David).

294. Lanius major, Pall. Zoogr. i. p. 401.

Rare at Pekin (David). Under the name L. mollis, Erersm.*, a specimen of this has been sent from Trans-Baikal.

295. Lanius SChach, L. ; Zool. 1858, p. 6228 ; Ibis, 1860 , p. 59 , 1861, p. 43, 1865, p. 356 , 1870, p. 240 ; P. Z. S. 1863 , p. 286.

Lanius chinensis, Gray, Zool. Misc. p. 1.

Lanius schach, var. formosa, Ibis, 1863, p. 270.

China generally ; Formosa; Hainan.

296. Lanius tephronotus (Vig. P. Z. S. 1831, p. 43).

Sent by Père David from Moupin.

297. Lanius fuscatus, Less.; Walden, Ibis, 1868 , p. 69,1870 , p. 241.

Lanius melanthes, Swinh. Ibis, 1867, p. 405.

South China; Hainan.

298. Lanius magnirostris, Less.; Ibis, 1867, pl. 6.

Lanius waldeni, Swinh. P. Z. S. 1870, p. 131, pl. 11.

Comes from Malacea to Central China to breed. Female, when fully adult, like the male.

299. Lanius bucephalus, Temm. \& Schleg. Faun. Jap. t. 14 ; Ibis, 1860 , pp. 60 et 132, 1861, p. 340 ; P.Z.S. 1862 , p. 319 , 1863 , p. 287.

Pekin; Amoy (one female specimen procured in winter). Male differs much from the female.

300. Lanius Cristatus, L.; Gmel. Syst. Nat. 1788, p. 298.

Lanius phonicurus, Pall.

Upper parts reddish brown; crown the same from the base of the beak; eyebrow yellowish and not well defined. A male from Amoy agrees with examples from India. Adult female resembles the male. Received frequently in full summer plumage from Trans-Baikal.

301. Lanius superciliosus, L.

Rather brighter than the last; forehead and well-defined eye[* $C f$. Ann. Nat. Hist. ser. 2, xvii. p. 78. - Ev.] 
brow white. A male from Amoy agrees with specimens from the Amoor and Malacca. Adult female resembles the male.

302. Lanius Lucionensis, L. ; Gmel. Syst. Nat. 1788, p. 299 ; Ibis, 1860 , p. 59 , 1861, pp. $43,255,340,1863$, p. 272,1866 , pp. 135, 295, 394 ; P.Z.S. 1863, p. 286, 1870, p. 428.

Lanius schwaneri, Bp. Consp. Av. i. p. 363.

Upper parts light liver-brown ; forehead greyish white, with welldefined white eyebrow. Adult female resembles the male. The commonest species that passes through Amoy. Those collected on passage through Formosa are all immature, as if they had not strength to make the through voyage to the Philippines without rest. L. schwaneri of Borneo seems, from the description, to be based on a partially mature female of this species. Found in summer as far north as Talien Bay.

\section{Lanius incertus, $\mathrm{n}$. $\mathrm{sp}$.}

Crown, from beak to occiput, cinereous, with no eyebrow ; rest of upper parts reddish brown, brighter on the rump. One male specimen procured at Amoy from a party of the last.

These four red-tailed Shrikes may be considered geographical races, or representative species, each reserving to itself an area in South-eastern Asia for its winter haunt, and another in North-eastern A sia for its summer haunt. The L. cristatus, that spreads throughout India in winter, seems to seek a family home in Dauria and the country directly north of India, extending to Trans-Baikal; L. lucionensis travels across the sea from its warm winter retreat in the Philippines, and spends its summer in North China, extending its range to Talien Bay; the southernmost species, $L$. superciliosus, comes from Malacca, and, passing the summer range of the latter, seeks the high latitudes of Amoorland and northern Japan as more suitable for the nurture of its offspring. As in the case of the Limicola, those that go furthest north to breed, hurry furthest south to escape the rigours of winter; such is, apparently, the case with L. superciliosus. But this is scarcely a rule with land-birds; for this Shrike's winter compatriot, $L$. magnirostris, as I have shown (P. Z. S. 1870, p. 131), is contented to accommodate himself at a halfway station on the journey in Central China. The route taken by $\boldsymbol{L}$. superciliosus is not down the China coast, or we should meet him straggling down in spring and autumn, as all the migrants do that travel by land. He probably takes the more inland course followed by many birds that summer in North China and the Amoor. How, then, does it occasionally turn up with the large flights of $\boldsymbol{L}$. lucionensis bound to the Philippines and Borneo? How, further, does it happen that $L$. cristatus should step out of its way and straggle on a tour to a country widely separate from its regular winter quarters? I would suggest as an explanation that the routes travelled by the three species must somewhere cross or touch, and that the outliers of the bird-caravans would get attracted to the 
allied throng with which they came into contact, and so pass on with it inadvertently. Thus it is matter of no great surprise that the typical $L$. lucionensis is occasionally obtained, as Mr. Blyth informs me, in Ceylon, whither it would have travelled with $L$. cristatus, or in the Tenasserim, whither the company of L. superciliosus would have conducted it. To account for this phenomenon I was before led to suppose that the variation of the three species was not constantly fixed, and that each race occasionally developed the peculiarities of either of the others. But my present hypothesis is, I think, the right one. There need be no confusion of races by the intercrossing of species, for the misguided birds would be among strangeris only for the winter; in the summer, on their return journey, they would have the opportunity of rejoining their species.

Lanius incertus is founded on one male specimen, and, from its being so different in plumage, will, I think, be found to belong to another geographical race, with winter and summer resorts of its own, which has, in a similar way, been allured from its ordinary course of migration.

304. Tephrodornis pelvica (Hodgs.); Ibis, 1870, p. 241.

Tenthaca pelvica, Hodgs. Ind. Rev. 1837, p. 447.

Hainan.

305. Artamus fuscus (Vieill.); Ibis, 1862, p. 306, 1870, p. 247 ; P.Z.S. 1863 , p. 287.

Hainan. Macao (Cassin, $v$. Perry's Exp. to Japan).

306. Dicrurus cathecus, n. sp.

D. macrocercus, Swinh. Ibis, 1860 , p. 59 , 1861, pp. 43,340 , 1863 , p. 266,1865 , p. 348 , 1866 , p. 121,1870 , p. 244 ; P.Z.S. 1862 , p. 319,1863 , p. 285,1870 , p. 433.

The term macrocercus has been applied in India to two distinct species of Black Drongos, - the one a long bird,always distinguishable by a white spot close to the gape, the D. albirictus of Hodgson; and the other allied to our Chinese bird. The name was given by Vieillot to the Java bird of this group-the Edolius longus, Temm., and $\boldsymbol{E}$. forficatus, Horsf. The Java species is smaller than the Indian bird, of more slender and elongated form, and has smaller feet. Our China bird, which is found throughout China, Hainan, and Formosa, is larger than its Indian ally, with longer bill and much longer wing, and has a rich bronze gloss over its feathers, including its wings and tail ; wing 6 inches, tail 6 . I propose to separate it specifically under the above name. Our Drongo, in its nestling plumage, is of a greyish black (which browns with wear), deeper on the upper parts, bronzed on its wings and tail, with white on its axillaries and carpal edge. In changing into the bronzed plumage of the adult, the feathers of the underparts appear with broad white margins, which gradually give place to uniform bronze. Young males often begin to acquire the adult plumage on leaving the nest. 
307. Buchanga mounoti, Walden, Ann. Mag. N. H. 4th ser. v. p. 220 ; Ibis, 1870, p. 245.

Hainan.

308. Buchanga leucogenys, Walden, Ann. Mag. N. H. 4th ser. v. p. 219 ; Ibis, 1870 , p. 245.

Dicrurus cineraceus, Ibis, 1861, p. 265, 1862, p. 258.

Dicrurus cinerascens, Ibis, 1861, p. 411.

Dicrurus leucophaus, P. Z. S. 1863, p. 285.

Hainan to Fouchow, and westward to Szechuen.

309. Buchanga innexa, Swinh. Ibis, 1870, p. 246.

Hainan.

310. Сhibia brevirostris, Cab. Mus. Hein. i. p. 112.

Chibia hottentotta (L.); Ibis, 1861, p. 411, 1863, p. 96 ; P.Z.S. 1862, p. 319, 1863, p. 285.

Amoy; Tientsin; Pekin (David). Outer tail-feather very broad and much curled, bill rather shorter, bronzed spots on breast rounder, frontal deflected bristles long and coarse; otherwise very similar to C. hottentotta of India.

311. Chaptia brauniana, Swinh. Ibis, 1863, p. 269, 1866, p. 399.

Formosa.

312. Graucalus Rex-Pineti, Swinh. Ibis, 1863, p. 265, 1966, pp. $393,402,1 \times 70$, p. 242.

Formosa ; Hainan.

313. Volvocivora melaschista, Hodgs. Ind. Rev. 1837, p. 328 ; P. Z. S. 1863 , p. 282.

Volvocivora lugubris, Sundev.

Campephaga cinerea?, Ibis, 1860, p. 58.

Campephaga —?, Ibis, 1861 , p. 42.

Canton to Foochow, and westwards to Szechuen. Summer visitant.

314. Volvocivora saturata, Swinh. Ibis, 1870, p. 242.

Hainan.

315. Pericrocotus cinereus, Lafresn. Rev. Zool. 1845, p. 94 ; Ibis, 1860 , p. 58,1861 , p. $42,340,1862$, p. 263,1870 , p. 244 ; P. Z. S. 1863 , p. 283.

Ranges from the South to Pekin.

316. Pericrocotus cantonensis, Swinh. Ibis, 1861, p. 42, 1865, p. 107, 1870, p. 244 ; P. Z. S. 1863, p. 284.

Pericrocotus sordidus, Swinh. (immature), P. Z. S. 1863, p. 284.

Northwards to Foochow, and westwards to Szechuen. 
317. Pericrocotus igneus, Blyth; J. Verreaux, Rev. et Mag. de Zool. (May 1867) p. 169.

Western China, Perny's collection (J. Verr.).

318. Pericrocotus brevirostris, Vig.; Gould, Cent. pl. 8.

Passes Pekin in migration, but does not breed in the Chelee province (David).

319. Pericrocotus griseigularis, Gould, P. Z. S. 1862, p. 282 ; B. of As. pl. ; Ibis, 1863, p. 263, 1866, p. 399.

Formosa ; Fokien province.

320. Pericrocotus speciosus (Lath.); Gould, Cent. pl. 7 ; Ibis, 1867, p. 403 ; P. Z. S. 1863 , p. 285.

Pericrocotus brevirostris?, Ibis, 1862, p. 257.

Fokien province.

321. Pericrocotus fraterculus, Swinh. Ibis, 1870, p. 244.

Hainan.

322. Butalis gkiseosticta, Ibis, 1866, p. 131, P. Z. S. 1863, p. 288.

Hemichelidon griseisticta, Swinh. Ibis, 1861, p. 330, 1863, p. 262.

Hemichelidon fuliginosa, Ibis, 1860, p. 57.

Butalis hypogrammica, G. R. Gray; Wallace, Ibis, 1862, p. 350. China in summer, winters in the Moluccas.

323. Butalis sibirica (Gmel.); P. Z. S. 1863, p. 288, 1870, p. 440.

Muscicapa sibirica, Gmel. Syst. Nat. 1788, p. 936.

Muscicapa fuscedula, Pall. Żoogr. i. p. 462.

Hemichelidon fuliginosa, Hodgs.

Amoy; Pekin.

324. Butalis ferruginea(Hodgs.); Ibis, 1870,p. 247 ; P.Z.S. 1863, p. 288.

Hemichelidon rufilata, Swinh. Ibis, 1860, p. 57.

Hemichelidon ferruginea, Hodgs. Ibis, 1861, p. 40.

South China; Hainan.

325. Butalis latirostris (Raffles), P. Z. S. 1863, p. 288.

Hemichelidon latirostris, Ibis, 1860, p. 57, 1861, pp. 40, 330, 1863 , p. 262.

Muscicapa latirostris, Raffles, 'Trans. Linn. Soc. xiii. pt. 2(1822), p. 312 .

Muscicapa cinereoalba, Temm. \& Schleg. Faun. Jap.; Ibis, 1870, p. 247.

Muscicapa grisola, var. daurica, Pall. Zoogr. i. p. 461.

Summers in China. 
326. Erythrosterna albicilla (Pall.); P. Z. S. 1862, p. 317.

Muscicapa albicilla, Pall. Zoogr. i. p. 462.

Erythrosterna leucura (Gmel.); Ibis, 1860, p. 357, 1863, p. 92, 1870 , p. 247 ; P. Z. S. 1863 , p. 290.

Erythrosterna mugimuki, Ibis, 1861, p. 330.

Thamnobia niveiventris, Swinh. Ibis, 1860, p. 54.

Winters in Southern China. Gmelin's Muscicapa leucura (Syst. Nat. i. 1788, p. 939) is from the Cape of Good Hope, and therefore cannot be our bird.

327. Erythrosterna luteola (Pall.); Midd. Sib. Reis. pl. xvii. (winter plumage); Ibis, 1866, p. 313 ; P.Z. S. 1863, p. 290.

Motacilla luteola, Pall.; Zoogr. i. p. 470.

Muscicapa mugimaki, T. \& S. Faun. Jap. (adult of in summer); Ibis, 1860 , p. 357,1867 , p. 390,1870 , p. 247.

Muscicapa hylocharis, Swinh. Ibis, 1862, p. 305 (young ot).

China coast and Formosa in autumn. Wanders down to Penang (E. erythaca, Blyth).

328. Muscicapula sapphira (Tick.); Jerd. Ind. Orn. pl. 32.

Western China (Perny's coll., Rev. et Mag. de Zool. 1867, p. 169).

329. Xanthopygia narcissina (Temm.) Pl. Col. 577 ; Swinh. Ibis, 1860 , p. 58,1861 , pp. $41,410,1870$, p. 247 ; P. Z. S. 1863 , p. 289.

Passes up and down the China coast. Summers in Japan.

330. Xanthopygia tricolor (Hartl.).

Xanthopygia leucophrys, Blyth, Ibis, 1861, p. 410, 1863, p. 92 ; P. Z. S. 1862, p. 317, 1863, p. 289.

Rare on the coast. Breeds near Pekin (David). Found in winter in Malacca.

331. Niltava sundara, Hodgs. Ind. Rev. 1837, p. 650 ; Gould, B. of As. pl.

Western China (Perny's collection, identified by J. Verreaux).

332. Cyornis vivida, Swinh. Ibis, 1864, p. 363 , 1866, p. 393 , pl. 11.

Formosa. The male is a mimicry of the last; the female, a true Cyornis, without the blue spot on the side of the neck that distinguishes females of the Niltava group.

333. Cyanoptila cyanomelena (Temm.) Pl. Col. 470 ; Ibis, 1870, p. 247.

Muscicapa gularis, T. \& Schleg. F. J. (ㅇ ).

Niltava cyanomelana, Ibis, 1860 ,p. 58,1861 , p. 41 , 1863, p. 92 ; P.Z. S. 1862 , p. 317 , 1863 , p. 290.

Hypothymis cyanomelana, Ibis, 1862, p. 306.

Passes up and down the China coast. Summers in Japan. 
334. Stoparola melanops (Vig.); Gould, Cent. pl. 6 ; Ibis, 1861, p. 263.

Eumyias melanops, P. Z. S. 1863, p. 289.

Amoy; Western China (Perny and Darid).

335. Siphia strophiata, Hodgs. Ind. Rev. 1837, p. 651.

Moupin, from Père David. The Paris Museum has received another species from the same locality allied to S. erithacus, Blyth, from Darjeeling.

336. Digenia superciliaris (Blyth, J. A. S. xi. p. 190); P. Z. S. 1845 , p. 26.

Siphia innexa, Swinh. Ibis, 1866, p. 394.

Siphia rubrocyanea, Hodgs.

Formosa. Known also from the Himalayas; and from Timor as Muscicapa tricolor o (rupestris + ), Müll.: see Blyth, Ibis, 1865, p. 44.

337. Myiagra azurea (Bodd.), Pl. En. 666; Ibis, 1861, p. 263,1863 , p. 261,1865 , p. 545,1870 , p. 247 ; P. Z. S. 1863 , p. 289.

Tchitrea caruleocephala?, Ibis, 1860 , p. 57.

Formosa ; Hainan; Amoy (one specimen).

338. Culicicapa cinereocapilla (Vieill.); Sw. Zool. Ill.pl.13.

Szechuen province, in the gorges of the Yangtsze river. The former generic name of this species (Cryptolopha) having been preoccupied, I propose to apply to it the above term.

339. Tchitrea princeps (Temm. Pl. Col. 584).

Tch. principalis, Ibis, 1860 , p. 57, 1861, pp. $39,411,1863$, p. 260 , 1865, p. 541 ; P. Z. S. 1863, p. 289.

Passes the South-China coast. Summers in Japan.

340. Tchitrea incei, Gould, B. of As. pl. ; Ibis, 1863, p. 92 ; P. Z. S. 1862 , p. 317,1863 , p. 289, 1870, p. 439.

T. principalis, Ibis, 1861, p. 330, 1866, p. 297.

Summers in Central and North China.

341. Garrulus sinensis, Gould, P. Z. S. 1863, p. 304.

G. ornatus, Ibis, 1861, p. 267, 1862, pp. 261, 263.

South China, westwards to Szechuen. Chinese specimens have longer legs and feet than the Himalayan $G$. bispecularis, Vigors; but I can detect no other difference.

342. Garrulus taivanus, Gould; P. Z. S. 1862, p. 282 ; B. of As. pt. xvi. ; Ibis, 1863 , p. 386.

Formosa. 
343. Garrulus brandti, Eversm. Addend. ad Pall. Zoogr. Rosso-Asiat. 1843, iii. p. 8.

North China; Pekin.

344. Urocissa sinensis (L.); Ibis, 1861, pp. 43, 267, 409, 1862 , p. 261,1865 , p. 349,1867 , p. 407 ; P. Z. S. 1863 , p. 304 , 1870 , p. 448.

Cuculus sinensis, Gmel. Syst. Nat. i. (1788) p. 418.

Corvus erythrorhynchus, Gmel. p. 372 .

Throughout China.

345. Urocissa Cerulea, Gould; P. Z. S. 1862, p. 282 ; B. of As. pl. ; Ibis, 1863, p. 384, 1866, pp. 121, 296, 303.

Formosa.

346. Dendrocitta sinensis (Lath.) ; Ibis, 1868 , p. 62,1870 , p. 351 ; P. Z. S. 1863 , p. 304 .

Corvus sinensis, Lath. Ind. Orn. i. p. 161.

South China; Hainan.

347. Dendrocitta formose, Swinhoe.

Dendrocitta sinensis, var. formosa, Ibis, 1863, p. 387, 1865, p. 234, 1866, pp. 296, 394 .

\section{Formosa.}

348. Nucifraga caryocatactes (L.); P. Z. S. 1863, p. 306, 1870 , p. 448.

Pekin.

349. Nucifraga hemispila, Vig.; Gould, C. B. pl. 36.

Sent from Moupin by Père David.

350. Pica media, Blyth, J. A. S. xiii. (1844), p. 393 ; Ibis, 1863, p. 383,1870 , p. 350 .

Pica sericea, Gould, P. Z. S. 1845 , p. 2 ; Ibis, 1860 , pp. 60 , 429, 1861, pp. 43, 336, 1867, p. 236.

Pica caudata, P. Z. S. 1863, p. 303.

Throughout China; Formosa; Hainan. Birds from Pekin and Kalgan are much more brightly coloured than southern examples.

351. Cyanopolius cyanus.

Corvus cyanus, Pall. Zoogr. R. A. i. p. 391.

Cyanopica cyana, Ibis, 1861 , p. 336 ; P. Z. S. 1863, p. 304.

Shanghai to Pekin, and westwards to Ichang (Hoopih province).

352. Convus Japonensis, Bp. Consp. Av. p. 386.

Corvus macrorhynchus, Schleg. Faun. Jap. t. 39.

Beyond the Great Wall. 
353. Corvus sinensis, Gould; Moore, Cat. Birds F. I. Co. ii. p. 556 ; Ibis, 1862 , p. 260,1863 , pp. $95,383,1870$, p. 348 ; P. Z. S. 1863, p. 305. 402.

Corvus colonorum, Swinh. Ibis, 1864, p. 427, 1866, pp. 296,

Corvus japonicus, Ibis, 1861, p. 337.

Corvus japonensis, Ibis, 1862, p. 260.

Throughout China; Formosa; Hainan.

354. Convus torquatus, Lesson, Traité d'Ornith. p. 328; P.Z.S. 1863, p. 305.

Corvus pectoralis, Gould, Ibis, 1860, p. 60,1861 , pp. 43, 337 , 1862 , p. 260 , 1867 , p. 411,1870 , p. 350 .

355. Corvus corone (L.); Ibis, 1870, pp. 79, 348.

Naochow Island, near Hainan.

356. Frugilegus pastinator.

Corvus pastinator, Gould, P. Z. S. 1845, p. 1; Ibis, 1861, p. 336 ; P. Z. S. 1863 , p. 305 .

Ningpo to Pekin.

357. Lycos Dauricus (Pall. Zoogr. t. 15); P. Z. S. 1863, p. 304.

Corvus dauricus, Ibis, 1861 , pp. 257, 337 .

Ningpo to Pekin. I cannot understand Prof. Schlegel (Mus. des Pays-Bas) considering the following species the young of this bird. I have taken this bird from the nest, and found the young beginning life with all the pied characters of the adult.

358. Lycos neglectus (Schleg. F. J. t. 40) ; P. Z. S. 1863, p. 305 .

Corvus neglectus, Ibis, 1861, pp. 259, 337, 1867, p. 227.

Ningpo to Pekin. This species is closely related to $L$. monedula, but has a mnch smaller and slenderer bill, and no grey on the sides of the head and neck. I have procured at Shanghai a hybrid between this and the last.

359. Fregilus graculus (L.), var. brachypus.

Fregilus graculus, Ibis, 1863, p. 95 ; P. Z. S. 1862, p. 319 , 1863, p. 306,1870 , pp. 434,444 .

Pekin. The Himalayan bird has much longer feet than ours, and scarcely any purple gloss on the body-plumage. Ours differs also from the European species by its tarsi being a good deal shorter and its toes quite stumpy. A bird from Siberia in the Cambridge Museum agrees with the Chinese bird.

360. Eulabes sinensis, Swinh. Ibis, 1870, p. 353.

South-west China. 
361. Eulabes hainanus, Ibis, 1870, p. 352.

Gracula, sp., Ibis, 1860 , p. 361 .

Hainan.

362. Acridotheres cristatellus (L.); Ibis, 1860, pp. 60, 429, 1861, p. 44, 1862, p. 260, 1863, p. 382 ; P.Z.S. 1863, p. 302.

Gracula cristatella, Gmel. Syst. Nat. 1788, p. 397.

Acridotheres philippensis, Ibis, 1867, p. 387, 1870, p. 352.

South China to Shanghai, and westwards to Szechuen; Hainan; Formosa.

363. Gracupica Nigricollis (Payk.); Act. Holm. xxviii. t. 9; Ibis, 1860 , p. 60 , 1861, pp. 44, 260 ; P. Z. S. 1863 , p. 303.

Pastor bicolor, Gray, Zool. Misc. p. 1.

Canton to Foochow.

364. Temenuchus sinensis (Gmel.); Ibis, 1866, p. 394, 1870, p. 352 .

Temenuchus turdiformis (Wagler) ; Ibis, 1860, p. 60, 1861, p. 44. Heterornis sinensis, Ibis, 1863 , p. 382, 1865, p. 358, 1866, p. 138 ; P. Z. S. 1863, p. 302.

Summers in South China from Canton to Foochow. Observed as a migrant in Formosa and Hainan. Winters in Pegu.

365. Temenuchus Dauricus (Pall. Act. Stockh. 1778, iii. p.198); Pl. Enl. 627. 3 ; Ibis, 1863, p. 95 ; P. Z. S. 1863, p. 302.

Gracula sturnina (Pall.); Gmel. Syst. Nat. 1788, p. 399.

Sturnus pyrrhogenys, Ibis, 1861, p. 338 .

Sturnus dauricus, Ibis, 1866, p. 131 ; P. Z. S. 1862, p. 319.

Procured at Tientsin and Pekin; would appear to summer in North-east Tartary, and to winter in Malacca and Java.

366. Sturnus cineraceus, Temm. Pl. Col. 556 ; Ibis, 1861, pp. $257,338,1863$, p. 382 , 1870 , p. 352 ; P. Z. S. 1862 , p. 319 , 1863 , p. 301 .

Temenuchus cineraceus (Temm.); Ibis, 1860, p. 60, 1861, p. 44.

Passes down the coast in winter. Breeds in North China. Found during winter in Formosa and Hainan.

367. Sturnus Sericeus, Gmel. Syst. Nat. 1788, p. 805 ; Ibis, 1861, p. 338 ; P.Z.S. 1863, p. 301.

Pastor sericeus, Gray, Zool. Misc. p. 1.

Temenuchus sericeus (Lath.); Ibis, 1860, p. 60, 1861, p. 44.

Sturnus cinereus, Ibis, 1862, p. 306.

Fokien and Canton provinces.

368. Munia sinensis (Briss.).

Coccothraustes sinensis, Briss. Orn. iii. p. 238. 
Munia rubronigra, Hodgs. Ibis, 1861, p. 45 ; Blyth, Ibis, 1860, p. 61 .

South-west China.

369. Munia formosana, Swinh. Ibis, 1865, p. 356.

Formosa.

370. Munia topela, Swinh. Ibis, 1863 , p. 380,1870 , p. 354 ; P.Z.S. 1863, p. 299.

Munia malacca, Ibis, 1860, p. 61, 1861, p. 45.

South China; Hainan; Formosa.

371. Munia acuticauda, Hodgs. As. Res. xix. (1836) p. 153 ; Ibis, 1863 , p. 379 , 1870 , p. 354 ; P. Z. S. 1863 , p. 299.

Munia molucca, Ibis, 1860, p. 61.

Munia minima?, Ibis, 1860, p. 358, 1861, p. 45.

Hainan to Shanghai, and westwards to Szechuen; Formosa.

372. Padda oryzivora (Linn.).

Oryzornis oryzivora, Ibis, 1860 , p. 60.

Munia oryzivora, Ibis, 1861, p. 45 ; P. Z. S. 1863, p. 299.

Hongkong; Amoy; Shanghai.

373. Fringilla montifringilla, L. ; Ibis, 1861, p. 335, 1864, p. 423 ; P. Z.S. 1862, p. 318,1863 , p. 298.

North China in winter. Occurs occasionally as far south as Amoy.

374. Chrysomitris spinus (L.); Ibis, 1861, p. 267 ; P. Z. S. 1863, p. 299, 1870, p. 433.

Fringilla spinus, Ibis, 1861, p. 335.

Pekin in autumn, and in winter down to Foochow.

375. Chlorospiza sinica (L.); P. Z. S. 1863, p. 299, 1870, p. 433.

Ligurinus sinicus, Ibis, 1860 , p. 61,1861, p. 45.

Fringilla sinica, Ibis, 1861 , p. 335,1863 , p. 378.

Canton to Pekin, and westwards to Ichang (Hoopih Province).

376. Pyrgita petronia (L.).

Breeds in the Ordo Mountains, north-west of Pekin (David). Père David, in his Catalogue, mentions an allied Finch which he has procured on the most elevated regions of Mongolia. This novelty will shortly be described by J. Verreaux.

377. Leucosticte brunneinucha (Brandt).

Seen in North Chelee in the coldest weather (David).

378. Fringillauda nemoricola, Hodgs. As. Res. xix. (1836) p. 158 ; Bp. Lox. t. 47.

Sent from Moupin by Père David.

Proc. Zool. Soc.-1871, No. XXV. 
379. Ægiothus borealis (Temm.).

Agiothus canescens, Gould; P. Z. S. 1863, p. 299.

Cannabina canescens, Ibis, 1861, p. 335.

Winters in North China.

380. Passer montanus (L.); Ibis, 1860 , p. 60,1861 , pp. 45 , 255 , 1863 , p. 378,1870 , p. 354 ; P. Z. S. 1863 , p. 299,1870 , p. 433.

Fringilla montana, Ibis, 1861, p. 335, 1862, pp. 258, 260.

The House-Sparrow of all China, Hainan, and Formosa.

381. Passer rutilans, Temm. Pl. Col. 288.

Passer russatus, Schleg. Faun. Jap.; Ibis, 1861, p. 45, 1863, p. 378,1866 , p. 295 ; P. Z. S. 1863 , p. 299.

South China and Formosa.

382. Passer cinnamomeus (Gould).

Pyrgita cinnumomea, Gould, P.Z.S. 1835, p. 185.

Occurs at Ichang, and westwards to Szechuen.

383. Passer ouratensis, David, in Mus. Pekin; Swinh. P. Z.S. 1870 , p. 430.

Ordo Mountains (David).

384. Coccothraustes vulgaris, var. Japonicus, Ibis, 1861, p. 336 ; P.Z.S. 1863 , p. 299, 1870, p. 448.

Coccothraustes vulgaris japonicus, T. \& S. Faun. Jap.

Shanghai to Pekin, and westwards to the Ichang gorge.

385. Eophona melanura (Gmel.); Gould B. of As. pl.; Ibis, 1867, p. 390.

Coccothraustes melanurus, Ibis, 1860, p. 61, 1861, p. 45; P. Z. S. 1863, p. 299.

Loxia melanura, Gmel. Syst. Nat. i. p. 853.

Throughout China.

386. Eophona Personata, Schleg. F. J. t. 52 ; P. Z. S. 1870, p. 448.

Pekin.

387. Mycerobas melanoxanthus, Hodgs.

Coccosthraustes melanoxanthus, Hodgs. As. Res. xix. (1836) p. 150.

Sent from Moupin by Père David.

388. Pyrrhula griseiventris, Lafr.

Pyrrhula orientalis, Temm. F. J. t. 58.

From Shanghai northwards. 
389. Pyrrhula erythrocephala, Vig. P. Z. S. 1831, p. 174 ; Gould, C. B. pl. 32 .

Sent from Moupin by Père David.

390. Carpodacus erythrinus (Pall. Zoogr. t. 36); Ibis, 1863, p. 95 ; P.Z.S. 1862 , p. 318 , 1863, p. 299.

Visits China in winter.

391. Carpodacus davidianus, M.-Edw. N. Arch. du Mus. i. t. 2,3 .

Breeds on the highest mountains near Pekin (David).

392. Carpodacus mongolicus, Swinh. P.Z. S. 1870, p. 447.

On the western hills near Pekin. Resident in Ordo (David). The Paris Museum has received three other species of this group from Moupin, which appear to be new. One of them has been wrongly referred to Pyrrha saturata, Bp.

393. Uragus sibiricus (Pall.)

Loxia sibirica, Pall. Itin. ii. Append. p. 711.

One specimen procured by Père David at Pekin.

394. Loxia Albiventris, Swinh. P. Z. S. 1870, p. 437.

Loxia curvirostra (L.), Ibis, 1861, p. 336 ; P. Z. S. 1863 , p. 299.

Pekin.

395. Loxia himalayana, Hodgs.; Gray's Zool. Misc. 1844, p. 85 .

Sent by Père David from Moupin.

396. Melophus melanicterus (Gmel.); P. Z. S. 1863, p. 300 .

Fringilla melanictera, Gmel. S. N. i. p. 910.

Emberiza lathami, Gray, Zool. Misc. p. 1.

Melophus lathami, Ibis, 1860, p. 62, 1561, p. 46, 1867, p. 233. South China.

397. Euspiza aureola (Pall. It. ii. p. 711); Ibis, 1860, p. 62, 1861, pp. 45, 334 ; P. Z.S. 1863 , p. 300.

Emberiza aureola, Ibis, 1863 , p. 378,1870 , p. 354.

China generally.

398. Euspiza rutila, Pall. It. iii. p. 698 ; P. Z. S. 1863, p. 300. Emberiza rutila, Ibis, 1861 , pp. 334,410 ; P. Z. S. 1862 , p. 318. Emberiza sinensis, Gmel. Syst. Nat. 1788, i. p. 869.

North China, wandering south in winter. 
399. Euspiza sulphurata ('Temm. \& Schleg.) Faun. Jap. t. 60 ; Ibis, 1860 , p. 359 , 1861 , pp. 46, 334 ; P.Z.S. 1863 , p. 300.

Emberiza sulphurata, Ibis, 1863, p. 378.

South China and Formosa in winter.

400. Еmberiza fucata, Pall. It. iii. p. 698 ; Faun. Jap. t. 57 ; Ibis, 1860 , p. 61,1861 , pp. $45,324,1863$, p. 378,1870 , p. 354 ; P. Z. S. 1863 , p. 301.

South China in winter.

401. Emberiza rustica, Pall. It. iii. p. 698 ; P. Z. S. 1863, p. 301 .

North China.

402. Emberiza spodocephala, Pall. It. iii. p. 698 ; Ibis, 1863 , p. 377,1870 , p. 354 ; P.Z.S. 1863 , p. 300.

Emberiza personata, Temm. Pl. Col. 580 ; Ibis, 1861, pp. 45, 334, 1862 , p. 258.

Euspiza personata, Ibis, 1860, p. 62.

South China and Formosa in winter.

403. Emberiza elegans, Temm. Pl. Col. 583.

North China and Moupin.

404. Emberiza elegantula, Swinh. P. Z. S. 1870, p. 134.

Ichang gorge (Hoopih province).

405. Emberiza chrysophrys, Pall. It. iii. p. 698 ; P. Z. S. 1863, p. 301 .

North China ; Szechuen.

406. Emberiza leucocephala, S. G. Gmel. Nov. Comm. Petrop. xv. p. 480.

Emberiza pithyornus, Pall. It. ii. p. 710 ; Ibis, 1863, p. 95 ; P. Z.S. 1863 , p. 300.

Emberiza —?, Ibis, 1861, p. 334.

Pekin.

407. Emberiza ciopsis, Bp.; P. Z. S. 1863, p. 300.

Emberiza cioides, Temm. \& Schleg. Faun. Jap. t. 59 ; Ibis, 1861, pp. 409, 410, 1863 , p. 378 ; P. Z. S. 1870 , p. 436.

Emberiza rustica, Ibis, 1861, p. 255, 1863, p. 87.

Emberiza gigliolii, Swinh. Ibis, 1867, p. 393.

South China in winter.

408. Emberiza tristrami, Swinh. P. Z. S. 1870, p. 441.

Emberiza stracheyi, Ibis, 1863 , p. 95 ; P. Z. S. 1862 , p. 318 , 1863 , p. 301.

Tientsin. Fokien in winter. 
409. Emberiza castaneiceps, Gould; Mopre, P. Z. S. 1855, p. 215.

Pekin. "Resident in the Pekin mountains and in Mongolia" (David).

410. Емвеriza pusilla, Pall. It. iii. p. 697 ; Ibis, 1860 , p. 61 , 1861, p. 334 ; P.Z.S. 1863 , p. 301.

North China; spreads south in winter.

411. Schenicola pallasii, Cab.

Emberiza schœniclus, var. minor, Midd. Sib. Reis. Vög. p. 144.

Emberiza canescens, Swinh. Ibis, 1860, p. 62, 1861, p. 334; P.Z.S. 1863 , p. 301.

Amoy in winter. River Yangtsze.

412. Plectrophanes nivalis (L.); P.Z.S. 1863, p. 301.

North China in the coldest seasons.

413. Plectrophanes lapponicus (L.); Ibis, 1861 , p. 334 ; P.Z.S. 1863, p. 301.

Common at Pekin in winter.

414. Alauda arvensis, L.; Ibis, 1863, p. 94 ; P. Z. S. 1863, p. 271.

Alauda pekinensis, P. Z. S. 1863, p. 89.

Alauda japonica, Ibis, 1861, p. 333.

"Arrives in Pekin and leaves again in April ; some individuals spend the summer in our plains. The Skylark, though known here and at Senen-hwa-foo, is not known in high Mongolia, where it is replaced by Otocoris and Calandrella" (David).

415. Alauda cantarella, Bp.; P.Z. S. 1863, p. 271.

Alauda intermedia, Swinh. P. Z. S. 1863, p. 89.

Shanghai.

416. Alauda celivox, Swinh. Zoologist, 1859, p. 6723; Ibis, 1860 , p. 62 , et pp. $132,429,1861$, p. 46,1867 , p. 227,1870 , p. 354 ; P.Z.S. 1863 , pp. $89,272$.

Amoy; Canton; Hainan.

417. Alauda Sala, Swinh. Ibis, 1870 , p. 354.

Alauda cœlivox (in part), Ibis, 1863, p. 377.

North Formosa; West Hainan.

418. Alauda wattersi, n. sp.

Alauda coelivox (in part), Ibis, 1863, p. 377.

Distinguishable from $A$. coelivox by its shorter and more conical bill, by its long hind claw, by its large and more numerous pectoral spots, and by its want of rufescence. By its long hind claw and markings it comes nearer to $A$. sala ; but the long curved bill of 
the latter serves at once to separate it. It is the Skylark of South Formosa and the Pescadores.

419. Galerida cristata (L.).

Galerida leautungensis, Swinh.; P. Z.S. 1863, p. 272, 1870, p. 433. Alauda leautungensis, Ibis, 1861, p. 256, 1863, p. 87.

Talienwan and Pekin valleys.

"Resident and common at the feet of our mountains and in Mongolia” (David).

420. Alaudula cheleËnsis, n. $\mathrm{sp.}$

Alauda brachydactyla, Swinh.; Ibis, 1861, pp. 255, 333.

Calandrella pispoletta, P.Z. S. 1863, p. 271.

Differs from $A$. pispoletta, from the banks of the Volga, in being smaller in all its proportions, in having a more pyrrhuline bill, in its more rufescent plumage, and in having its outer tail-feathers almost entirely white.

Talien Bav. "Not rare at Pekin, but particularly abundant in Mongolia" (David).

\section{Catandrella brachydactyla (Leisl.)?}

A short-toed Lark with unspotted breast has been received at the Paris Museum from Moupin, which looks like the Indian bird. The second species at Pekin mentioned by Père David in his Catalogue may also possibly be this species.

422. Melanocorypha mongolica (Pall.); Ibis, 1861, p. 333 , 1867 , p. 232 ; P. Z. S. 1863 , p. 271.

Pekin plains in winter; very common in Mongolia (David).

423. Отоcorys alpestris (L.).

The Alpine Lark with the yellow throat only comes to the northern parts of the Chelee Province during the great cold (David). It has been sent from Trans-Baikal.

424. Отосоrys sibirica, Eversm.

Otocoris alpestris, Swinh. P. Z. S. 1863, p. 272.

Otocoris penicillata, Ibis, 1863, p. 95 ; P.Z.S. 1862, p. 318.

Differs from the last in having a white face, and in being of a paler rosier hue above. "Sedentary and very abundant in the high regions of Mongolia, whence it descends to Pekin in small numbers. This pretty Lark loves the neighbourhood of Mongol tents in winter; but deserts them in the warm season. It rests on the bare hills, and sings more melodiously than even the Skylark." (David.)

425. Paleornis lathami, Finsch, Papageien, ii. p. 66.

Palcoornis —?, Ibis, 1867 , p. 389.

Palcoornis javanicus, Ibis, 1870 , p. 93.

Hainan. 
426. Paleornis rosa (Bodd.); Ibis, 1861, p. 411 ; P. Z. S. 1863, p. 259.

Canton. Our bird agrees with Burmese examples, and differs from the allied $P$. cyanocephalus, L. (Ps. bengalensis, Brisson), of Bengal. The latter can easily be distinguished by the long white tips to its central tail-feathers, by its brighter-coloured head, its verditergreen nape, and yellow back and underparts.

\section{Palaornis longicauda (Bodd.).}

Birds of this species are sold at Canton, and said to come from South-west China.

A fourth species, with a grey head (perhaps P.schisticeps, Hodgs.), is brought down the Upper Yangtsze ; but, as I lost my only specimen, I have not been able to determine it. It was about the size of $\boldsymbol{P}$. alexandri, with smaller bill, general colour green with grey cheeks, black mandibles, and a black moustache-streak.

428. Loriculus puniculus, Bp.

Brought by Mr. Fortune from Canton.

429. Megalema virens (Bodd.); Ibis, 1861, p. 411 ; P. Z.S. 1863, p. 269.

Bucco grandis, Gmel. S. N. i. p. 408.

Fokien and Canton provinces. Differs from the large Barbet of the Himalayas, with which it has long been confounded, and which I have lately separated as M. marshallorum (Ann. \& Mag. Nat. Hist. 4 th ser. vi. p. 348 ).

430. Megat.ema nuchalis, Gould, P. Z. S. 1862, p. 283 ; B. of As. pt. xvi. ; Ibis, 1863, p. 387, 1865, p. 545, 1866, p. 296.

Formosa.

431. Megalema faber, Swinh. Ibis, 1870 , pl. 4 , p. 96 .

Hainan.

432. Picus mandarinus, Gould, P.Z.S. 1863 , pp. 88, 268 ; Ibis, 1870 , p. 94 .

Picus major?, Ibis, 1861 , p. 46, 1863, p. 96 ; P.Z.S. 1862, p. 319.

Picus cabanisi, Ibis, 1861, pp. 267, 339.

Hainan to Pekin and westwards to Szechuen. The white markings vary much in size and distribution, and the white feathers get stained to brown, but wash white again on the application of soap and water.

433. Picus majoroides, Hodgs.; Gray's Zool. Misc. 1844, p. 85.

Sent by Père David from Moupin, together with a new species of the same type, and another new species allied to Picoides tridactylus (L.). 
434. Picus insularis, Gould, P. Z. S. 1862, p. 283 ; B. of As. pl. ; Ibis, 1863, p. 390.

Formosa.

435. Picus pernyiI, J. Verreaux, Rev. et Mag. de Zool. 1867, p. 271.

"Nearly the size of $P$. cathpharius, Hodgs.; to be distinguished by the whitish which covers the neck, by the black line which, in reaching the breast, spreads on the belly, and above all by the red patch on the thorax, of which there is no trace in Hodgson's species." (J. Verreaux.)

Western China (Perny and David).

436. Yungipicus scintilliceps (Swinh.).

Picus scintilliceps, Swinhoe, Ibis, 1863, p. 96 ; P. Z. S. 1863, p. 268.

Picus canifrons, Sundevall, Consp. Av. Picin. (1866), p. 26.

Picus — ? Ibis, 1861, p. 340.

Pekin.

437. Yungipicus KaleËnsis (Swinh.).

Picus kaleënsis, Swinh. Ibis, 1863, p. 390, 1866, pp. 134, 137, 1870, p. 95 .

Dendrotypes nesiotes, Cab. \& Heine, Mus. Hein. Heft ii. p. 49.

Formosa; Hainan; South China to Ningpo and westward to Ichang.

438. Hypopicus poliopsis.

Picus hyperythrus, P. Z. S. 1862, p. 319.

Picus hyperythrus, var. poliopsis, Swinh. P. Z. S. 1863, p. 268.

Picus poliopsis, Swinh. P. Z. S. 1870, p. 440.

Picus — ?, Ibis, 1861, p. 339, 1863, p. 96.

Xylurgus subrufinus, Cab. \& Heine, Mus. Hein. v. p. 50.

Pekin.

439. Dryocopus martius (L.); P.Z. S. 1870, p. 442.

Pekin.

440. Gecinus Canus(Gmel.); Ibis, 1861, p. 338 ; P. Z. S. 1862 , p. 319,1863 , p. 267.

Pekin.

441. Gecinus Guerini, Malh. Pic. t. 80. 4, 5; P. Z. S. 1863, p. 268.

Along the Yangtsze to Szechuen.

442. Gecinus tancola, Gould, P. Z. S. 1862, p. 283, 1863, p. 268 ; B. of As. pl.; Ibis, 1863, p. 389.

Gecinus — ?, Ibis, 1861, p. 267.

Formosa ; Fokien province. 
443. Micropternus fokiensis (Swinh.), P. Z. S. 1863, p. 267. Brachypternus bodius, Ibis, 1861, pp. 267, 409.

Brachypternus fokiensis, P. Z. S. 1863, p. 87 ; Ibis, 1867, p. 63. Fokien province.

444. Micropternus holroydi, Swinh. Ibis, 1870, p. 95.

Hainan.

445. Yunx Japonica, Bp. Consp. Ar. p. 112.

Yunx torquilla, L. ; Ibis, 1860, p. 62, 1861, p. 338, 1862, p. 260; P. Z. S. 1862 , p. 319,1863 , p. 267.

Down the China coast in winter. Smaller than the European bird, but otherwise alike.

446. Zanclostomus tristis (Less.); Bélang. Voy. t. i.; Ibis, 1870, p. 234.

Melias tristis, Less. Tr. d'Orn. 1831, p. 132.

Hainan.

447. Centropus sinensis (Steph.); Ibis, 1861, p. 49.

Centropus rufipennis (Illig.) ; Ibis, 1870, p. 234 ; P. Z. S. 1863, p. 266.

Polophilus sinensis, Ibis, 1861, p. 267.

South China, northwards to Wanchow, and in Hainan. I can find no distinctive characters between the Chinese and Bengalese specimens; but birds from Siam have the back chestnut as well as the scapulars, $=C$. eurycercus, A. Hay. The Java bird is coloured like ours, but is of larger size, and has a much larger bill, $=C$. rufipennis, Illig. (bubutus, Horsf.).

448. Centropus bengalensis (Gmel.).

Cuculus bengalensis, Gmel. Syst. Nat. 1788, i. p. 412.

Cuculus, sp., Ibis, 1860, p. 359, 1861, p. 48.

Cuculus dimidiatus?, Ibis, 1860, p. 360 .

Cuculus viridis, Ibis, 1863 , p. 392,1870 , p. 235 ; P. Z. S. 1863 , p. 266.

South China, Hainan, and Formosa. Birds from the same locality extremely variable in size. Our birds agree with specimens from Bengal, Malacca, Java, and some of the isles. From Timor I have seen a larger species, the $C$. moluccensis, Bernst. (medius, G. R. Gr.), which by its similar immature plumage is connected with the present species, but in size almost approaches the foregoing. The second or streaked plumage of the $\boldsymbol{C}$. bengalensis is peculiar for the enormous length of the upper tail-coverts, which nearly cover the surface of the tail to its end. In the first or nestling plumage, and in the adult or rufous-and-black plumage, these coverts are short. In this intermediate dress it is recognized as the $C$. lepidus of Horsfield. 
449. Eudynamis maculata (Gmel.).

Cuculus maculatus, Gmel. Syst. Nat. 1788, i. p. 415.

Eudynamis orientalis, Ibis, 1861, p. 46, 1866, p. 131, 1867, p. 59 ; P. Z. S. 1863 , p. 264.

Summers and breeds about Canton; occurs occasionally as high as Amoy.

450. Eudynamis malayana, Cab. \& Heine; Swinh. Ibis, 1870, p. 231.

Plentiful in Hainan.

451. Coccystes coromandus (L.).

Cuculus coromandus, Linn. S. N. i. p. 171.

Coccystes coromandus, var. fuliginiventer, Ibis, 1867, p. 227.

Amoy. A specimen from Malacca has the abdomen nearly as dusky as the bird procured at Amoy.

452. Surniculus dicruroides (Hodgs.).

Pseudornis dicruroides, Hodgs.; J. A. S. Beng. viii. 1839, p. 136.

Procured by me near Chungkingfoo, in Szechuen, in May.

453. Cacomantis tenuirostris (J. E. Gray), Ind. Zool. ii. 1833 , t. 34 , f. 1 .

Polyphasia tenuirostris, Ibis, 1870, p. 230 ; P. Z. S. 1863, p. 266.

Cuculus tenuirostris, Swinh. Ibis, 1860, p. 62, 1861, p. 46.

Comes to South China to breed; occurred also in Hainan. Chinese specimens appear to agree with some procured in the neighbourhood of Calcutta ; and Lord Walden identifies it with the Burmese species.

454. Chrysococcyx hodgsoni, Moore, Cat. Birds Mus. E.I.C. ii. p. 705 ; Jerd. B. of Ind. i. p. 338.

Lampromorpha plagosus, Bp. Rev. et Mag. de Zool. (Mai 1867) pp. $169,173$.

Forwarded by Monseigneur Perny to the Paris Museum from Western China.

455. Cuculus sparveroides, Vigors, P. Z. S. 1531, p. 173; Gould, C. of B. pl. 53 ; V. Schrenck, Amur-Land, i. p. 24, t. 10.

Hierococcyx fugax, Swinh. P. Z. S. 1863, p. 265.

Very common in spring in the hilly region of the Upper Yangtsze, as far west as Moupin. Has occurred also in Amoorland. A noisy bird, crying loudly from the tops of trees, often during the night. Its note resembles somewhat that of the Koel, for which it was mistaken by Capt. Blakiston's party on the Yangtsze. The Koel does not occur in that region. 
456. Cuculus flaviventris, Scop.; Sonn. Voy. t. 79.

Cuculus hyperythrus, Gould, B. of As. pt. viii.

Mr. Gould figures a bird said to have come from Shanghai; but the only bird that I can find in the British Museum answering to this description is labelled "Manilla." I included this species in my former catalogue (P. Z. S. 1863, p. 265) in the belief that I had an immature specimen of it from Shanghai; but this last I now find belongs to the following species. It is not, improbable, however, that this species may occur in China.

457. Cuculus micropterus, Gould, P. Z. S. 1837, p. 137.

Cuculus affinis, A. Hay, J. A. S. B. xv. 18 (large variety).

Cuculus michieanus, Swinhoe, Ann. \& Mag. Nat. Hist. vol. vi. 4th series, p. 153.

This very distinct species may at once be recognized by its brown back, wings, and tail, the latter with a broad black bar at the end, connecting the subgenus Hierococcyx with the true Cuckoos. It is almost divisible into two varieties, of larger and smaller form; but these do not differ in notes according to Jerdon, nor indeed are they constant in size. I found the species on the Upper Yangtsze in company with the $C$. sparveroides, but not so common. Our birds are of the large form. They were very noisy, flying from tree to tree in an agitated manner, and uttering notes which are well syllabled in its Bengalese name, Bou-kotáko. I have an immature bird of the same from Shanghai, as noted under the foregoing species (P. Z. S. 1863, p. 265).

458. Cuculus canorus, L.; Ibis, 1860, p. 62, 1863, p. 96 ; P. Z. S. 1862, p. 319, 1863, p. 264.

Cuculus striatus, Ibis, 1861, pp. 259, 340 (in part).

This bird occurs in the mountains of the south in spring, extending northwards to Pekin. During its migration we meet with it on the plains. Its note is precisely that of the home bird, and I can detect no constant peculiar characters in its plumage to entitle it to separation from the European bird.

459. Cuculus poliocephalus, Lath. Hist. of B. iii. p. 181.

Cuculus himalayanus, Gould, Cent. pl. 54 (hepatic plumage); P. Z. S. 1863 , p. 265.

Cuculus tamsuicus, Swinh. Ibis, 1865, p. 108.

A miniature of the last. I have specimens from Tamsuy (N.W. Formosa), Amoy, and Szechuen.

460. Cuculus striatus, Drapiez, Dict. Class. d'Hist. Nat.; Ibis, 1862, p. 263.

Cuculus himalayanus, Vig.; Jerd. B. of Ind. p. 323.

Cuculus striatus, Ibis, 1861, pp. 259, 340 (in part.).

Cuculus tenuirostris, Temm. 
Cuculus canoroïdes, S. Müll.

Cuculus optatus, Gould.

Cuculus canorus, Ibis, 1863, p. 396.

Cuculus monosyllabicus, Swinh. Ibis, 1865, p. 545.

Cuculus kelungensis, Swinh. Ibis, 1863, p. 394.

I have a large series of this form of Cuckoo from Amoy, Formosa, and Pekin, and find them so variable in size, and in length and form of bill, that I give up in despair making species of them. From South Formosa I got a specimen with small bill and peculiar note; this I described as $C$. monosyllabicus; but it agrees with a specimen from Java labelled C. tenuirostris, Temm., sent me by Prof. Schlegel; and a series from Amoy and a bird from Pekin are also the same. From North Formosa I procured birds with large and long bills. These I described as $C$. kelungensis, and I have a specimen from Amoy with the same features (noted as C. micropterus, P. Z. S. 1863, p. 265); but they do not possess a single other character to distinguish them. From Amoy I have one with a particularly short and broad bill, but also with no other character; and a second with a thick curved bill, of large size, and with all the claws deep black. This last I determined as C. canoroides of S. Müller; but on glancing through my series I find many of the lesser and small-billed form, as also many of the long-billed form, with more or less black claws, in fact almost every gradation from pure yellow to black. I come therefore (I must confess, most reluctantly) to the conclusion that they all belong to the same variable species.

Like all the Cuckoos, these birds in China are only summer visitants.

461. Treron Formose, Swinh. Ibis, 1863 , p. 396,1865 , p. 540 , 1866, p. 312.

South Formosa.

462. Sphenocercus sororius, Swinh. Ibis, 1866, pp. 311, 406 .

Sphenocercus formosa, ơ, Ibis, 1866, p. 122.

Treron choroboatis, Ibis, 1866, pp. 313, 406.

South Formosa. Like Treron sieboldii, T. \& S., of Japan, but yellower about the head, and with the green of the back, wings, and tail clearer and not washed with the brownish oil-colour of the other.

463. Osmotreron domvilit, Swinh. Ibis, 1870 , p. 354 .

Hainan.

464. Carpophaga sylvatica (Tick.); Ibis, 1870, p. 355.

Columba sylvatica, Tickell, J. A. S. ii. p. 581 .

Hainan.

465. Columba livia, Briss. Av. i. p. 82 ; P. Z. S. 1870, p. 444.

In a feral state about the Pekin plains. 
466. Columba rupestris, Bp. Consp. Av. ii. p. 48 ; P. Z. S. 1863 , p. 306,1870 , p. 434.

Columba onas, var. rupestris, Pall. Zoogr. t. 35.

Columba leucozonura, Swinh. Ibis, 1861, p. 259, 1863, p. 88.

North China.

467. Dendrotreron hodgsonit (Vig.); Bp. Ic. Pig. t. 61.

Columba hodgsonii, Vigors, P. Z. S. 1832, p. 16.

Sent from Moupin by Père David.

468. Palumbus pulchricollis (Hodgs.); Gould, B. of As. pl.; Ibis, 1866, pp. 313, 396.

Columba pulchricollis, Hodgs. J. A. S. xiv. p. 866.

Formosa.

469. Coccyzura minor.

Macropygia tusalia, var. minor, Swinh. Ibis, 1870, p. 355.

Hainan.

470. Turtur rupicola (Pall.); Ibis, 1863, p. 397, 1865, p. 541, 1866 , p. 313 , 1867 , p. 396 , 1870 , p. 356 ; P. Z. S. 1863 , p. 306.

Turtur orientalis (Lath.); Ibis, 1860, p. 63, 1861, pp. 49, 341.

Turtur gelastes, T. \& S. F. J.; Ibis, 1862, p. 261 ; P. Z. S. 1870, p. 446.

South China, Formosa, and Hainan in winter. Differs considerably from T. meena, Sykes, of India.

471. Turtur chinensis (Scop.); Ibis, 1860, p. 62, 1861, p. 49, 1862 , p. 2 i l, 1863 , p. 397 , 1865, p. 540,1870 , p. 356 ; P.Z. S. 1863, p. 306.

South China; Hainan; Formosa.

472. Turtur risorius, L. ; Pl. Enl. 244 ; P. Z.S. 1870, p. 446.

Turtur risorius (albino), Ibis, 1865, p. 541, 1866, p. 298.

About the trees of villages near the Great Wall, but not at Pekin itself.

473. Turtur humilis, Temm. Pl. Col. 258, 259 ; Ibis, 1860, p. 63,1862 , p. 261,1863, p. 397,1865, p. 540,1870, p. 356 ; P. Z. S. 1863 , p. 306.

South China to Shanghai; Formosa; Hainan.

474. Chalcophaps indica (L.); Ibis, 1870 , p. 356.

Hainan.

475. Chalcophaps formosana, Swinh. Ibis, 1865 , pp. $357,540$.

Formosa, south of Takow. 
476. Syrrhaptes paradoxus (Pall. It. t. 5); Ibis, 1861, p. 341 ; P. Z. S. 1863, p. 306.

Breeds in Mongolia, roaming to the Pekin plains in winter (David).

477. Pavo muticus, L.; Ibis, 1870 , p. 359 , note.

South-west China.

478. Polyplectron bicalcaratum (L.).

Polyplectron chinquis, P. Z. S. 1863, p. 307.

South-west China.

479. Phasianus torquatus (Gmel.); Ibis, 1861, pp. 49, 341, 1862, p. 259 , 1865, p. 349 , 1867, pp. $232,390,402$; P.Z.S. 1863 , p. 307 .

Canton to Pekin, and westwards to Hankow.

480. Phasianus formosanus, Elliot, P. Z. S. 1870, p. 406.

Phasianus torquatus, Swinh. Ibis, 1863, p. 401, 1866, p. 404. Formosa.

481. Phasianus decollatus, Swinh. P. Z. S. 1870, p. 135. Province of Szechuen.

482. Phasianus sladeni, Anderson, MS.; Elliot, P. Z. S. 1870 , p. 408.

Phasianus elegans, Elliot, Ann. \& Mag. Nat. Hist. 4th series, vi. p. 312 .

Brought down the Upper Yangtsze, probably from Kwirchow province, and now alive in the Society's Gardens. Procured by Dr. Anderson in Momien, province Yunnan. There is a specimen apparently of this species in the British Museum, which was received many years ago from this Society, and was at the time supposed to be a cross between $\boldsymbol{P}$. colchicus and $\boldsymbol{P}$. versicolor of Japan.

483. Syrmaticus reevesii (Gray), Ind. Zool. pl. 39.

Phasianus reevesii, P. Z. S. 1863, p. 307.

Eastern Szechuen, Western Hoopih, and northwards to near Pekin.

484. Chrysolophus pictus (Linn.).

Thaumalea picta (L.); P. Z. S. 1863, p. 307.

Western China into Kokonor.

485. Chrysolophus amherstia (Leadb.).

Thaumalea amherstia, Leadb. Linn. Tr. xvi. pl. 15; Swinh. P. Z. S. 1863 , p. 307,1870 , p. 111.

Moupin; Western Yunnan (Dr. Anderson). 
486. Pucrasia xanthospila, G. R. Gr. P. Z. S. 1864, p. 159, pl. 20.

Pucrasia davidiana, M.-Edwards, N. Arch. du Mus. i. t. 1, 2, 3. North-west China.

487. Crossoptilon auritum (Pall.).

Phasianus auritus, Pall. Zoogr. ii. p. 86.

Crossoptilon carulescens, David, MS.; M.-Edw. C. R. 1870, p. 538.

Kokonor (David).

488. Crossoptilon mantchuricum, Swinh. P. Z. S. 1862, p. 287,1863 , p. 306 ; Ibis, 1865, p. 112.

North China into Mantchuria.

489. Crossoptilon drouynit, Milne-Edwards, N. Arch. du Mus. iv. (1868), Bull. p. 85, pl. 3 .

Crossoptilon tibetanum, Hodgs.?

Sent from Moupin by Père David.

490. Euplocamus nycthemerus (L.).

South China.

491. Euplocamus swinhoir, Gould, P. Z. S. 1862 , p. 284 ; B. of As. pl.; Ibis, 1863, p. 401, 1865 , pp. $353,538,1866$, pp. 133, $308,404,405,1867$, pp. 232, 409.

Formosa.

492. Lophophorus L'huysir, J. Verr. Bull. Soc. d'Acclimat. 2de sér. iv. (1867) p. 706; Sclater, P. Z. S. 1868, p. 1, pl. l.

Moupin.

493. Gallus ferrugineus (Gmel.); Ibis, 1870, p. 357.

Phasianus gallus, L. ; Ibis, 1867, p. 233.

Hainan.

494. Tetraophasis obscurus, Elliot, Mon. Phas. pt. iii.

Lophophorus obscurus, J. Verr. N. Arch. du Mus. 1869, Bull. p. 33 , pl. 6 .

Moupin (David).

495. Ceriornis temminckir (Gray); Swinh. P. Z. S. 1863, p. 307 .

West China.

496. Ceriornis cabotil, Gould, P. Z. S. 1857 , p. 161; B. of As. pl.; Ibis, 1865 , p. 350 ; P. Z. S. 1863 , p. 307.

South-west China. 
497. Ithaginis geoffroyi, J. Verr. Bull. Soc. d'Acclimat. 2de série, iv. (1867) p. 706.

Moupin (David).

498. Francolinus sinensis (Osb.); Ibis, 1870 , p. 359 ; P. Z. S. 1863, p. 307.

Francolinus perlatus (Gmel.); Ibis, 1860, p. 63, 1861, p. 50, 1862, p. 259, 1867, p. 406.

Francolinus maculatus, Gray, Zool. Misc. p. 2.

South China, Canton to Amoy; Hainan.

499. Perdix barbata, Verr. et Des Murs, P. Z. S. 1863, p. 62, pl. 9. pp. 307,370 .

Very common in Mongolia; rarer on the bare mountains near Pekin; never on the plain (David).

500. Oreoperdix crudigularis, Swinh. Ibis, 1864, pp. 426, 426,1865 , p. 542, 1866, pp. 133, 134, 401.

Formosa.

501. Bambusicola thoracica (Temm.); P. Z. S. 1863, p. 307.

Perdix sphenura, Gray, Zool. Misc. p. 2.

Arboricola bambusa, Ibis, 1862, p. 259.

Fokien province to south bank of Yangtsze.

502. Bambusicola sonorivox, Gould, P. Z. S. 1862, p. 285 ; B. of As. pl. ; Ibis, 1863 , p. 399 , 1865, p. 542, 1866, pp. 134, 40l, 404.

Formosa.

503. Bambesicola Fytchiı, Anderson, P. Z. S. 1871, anteà, p. 214, Pl. XI.

Procured by Dr. Anderson at Ponsee (Yunnan province).

504. Caccabis chukar, var. pubescens, Ibis, 1865, pp. 353, 542, 1867, p. 402 ; P. Z. S. 1870 , p. 439.

Perdix chukar, Gray, Hardw. Ill. Ind. Zool. i. pl. 54.

North China, southwards to north bank of Upper Yangtsze, in the gorges. Chinese specimens have a deep blush of rosiness over their upper plumage, which is not seen in Himalayan skins.

505. Lerwa nivicola (Hodgs.).

Sent from Moupin by Père David.

506. Tetrastes bonasia (L.).

Northern Chelee (David).

507. Tetrao tetrix, $L$.

Northern Chelee (David). 
508. Coturnix communis, Bonn. Ibis, 1863 , p. 398 ; P. Z. S. 1863, p. 308.

Coturnix chinensis (L.), Ibis, 1860, p. 63.

Coturnix dactylisonans, Ibis, 1860, p. 358, 1861, pp. 50, 260, 341 . Coturnix japonica, Bp.

The Quails of North China that come south in winter have more or less rufous on their faces, and are more richly coloured than those that pass the summer with us; but the two races seem to blend into each other, and it is not easy to draw a line of distinction between them.

509. Excalfactoria chinensis (L.); Ibis, 1863, p. 398, 1870, p. 360 ;'P. Z. S. 1863 , p. 308.

Coturnix chinensis (L.); Ibis, 1861, p. 50.

Coturnix caineana, $q$, Swinh. Ibis, 1865, p. 351.

South China, Formosa, and Hainan.

\section{Turnix dussumieri.}

Hemipodius dussumieri, Temm. Pl. Col. (1838) pl. 454. f. 2; Gould, B. of As. pt. xxi.

Turnix sykesi, A. Smith, Zool. of South Africa; Jerdon, B. of Ind. iii. p. 600.

In the winter 1868-69, when I was last in Formosa, I procured several females and one male of the little Turnix that abounds on the low grassy hills about fifteen miles from Takow. It had escaped me before, but its eggs I had got in abundance. This I cannot distinguish from the small Button-Quail of India. The females were bigger than the male, but of similar plumage. They both had deepbluish bills, and the former bluish grey legs, the legs of the male being more flesh-coloured. This bird has not yet been met with in China.

\section{Areoturnix rostrata.}

Turnix rostrata, Swinh. Ibis, 1865, pp. 542, 544, 1866, pp. 131, $297,403,1867$, p. 230.

Turnix ocellatus, Ibis, 1863, p. 398.

Allied to T. plumbipes, Hodgs., T. ocellata, Jerdon (nec Scop.), but of a good deal larger size, with much more powerful bill and legs. Frequents the lowest hill-ranges of South Formosa, showing a preference for rocky places covered with scrub. The female is much larger than the male, and acquires a black throat in summer.

\section{Areoturnix blakistoni, n. sp.}

Turnix ocellata, Ibis, 1866, p. 131 ; P. Z. S. 1863, p. 308.

A male specimen of the $\boldsymbol{T}$. ocellata group was procured by Capt. Blakiston at Canton, and kindly given to me. This differs too much from the last for me to consider it of the same species. Its nearest ally is the $\boldsymbol{T}$. pugnax, Temm., of Malacca, but it is smaller, shorter-toed, and possesses a remarkably small bill. Instead of spots

Proc. Zool. Soc.-1871, No. XXVI. 
it has numerous bands across the breast; and its upper parts are very rufous. I propose to separate it under the name of its discoverer.

513. Hemipodius viciarius, $\mathrm{n}$. $\mathrm{sp}$.

Turnix jondera, Hodgs.?; Swinh. Ibis, 1861, p. 50.

Turnix dussumieri, Ibis, 1861, p. 341.

Turnix maculosa, Ibis, 1866, p. 131 ; P. Z. S. 1863, p. 308, 1870 , p. 442.

The Indian species of this group is the Turnix jondera, Hodgs., figured in Gray and Mitchell's 'Genera of Birds' ( $T$. dussumieri, Jerd. B. of India, iii. p. 599); and a similar but larger bird is found in Burmah (T. Blanfordi, Blyth, J. A. S. B. 1863, p. 80). The latter from its size (wing 4 inches) seems to answer to the original Hemipodius maculosus, Temm. Pig. et Gall. iii. p. 631, 1815 (maculatus, Vieill. Gal. des Ois. 1834, iv. p. 51, pl. 217), the locality of which is doubtfully given as New Holland. Our bird, which ranges from Canton to Pekin, differs from these in wanting the red collar and the median stripe on the crown. The feathers on the crown are black margined with reddish brown, the breast is bright buff; the feathers of the back and rump are blotched and finely waved with black, and most of them have long ochreous spots on their margins. It is about the size of $T$. blanfordi, and in general plumage pretty similar. Irides white. Upper mandible brown ; lower mandible and legs ochreous yellow. The females are rather larger than the males, but do not seem to differ in plumage. The gizzard of a female was large and heart-shaped; cæca long and bulging; its trachea swollen above the junction with the bronchi.

514. Otis TaRda, L.; P. Z. S. 1863, p. 308.

“Tungusis Dauuriæ Todok," Pallas, Zoogr. ii. p. 97.

Shanghai and Hankow in winter. "Pekin in winter" (David).

I have a female specimen from Shanghai, which is smaller than the ordinary European bird, and more broadly banded with black on the upper parts.

Père David speaks of a smaller Bustard, called by the Chinese at Pekin "Kepoo." He saw a flock of them in Mongolia (Catalogue des Oiseaux à Pékin).

515. Grus cinerea, Bechst.; Ibis, 1861, p. 409, 1870, p. 362 ; P. Z. S. 1863 , p. 308 ; Zoologist, 1861, p. 7507.

South China in winter. Passes over the Pekin plain in September and April; commoner towards Mongolia (David).

516. Grus monachus, Temm.; Ibis, 1867, p. 413 ; P. Z. S. 1863 , p. 309 .

Shanghai market in winter.

517. Grus leucauchen, Temm.

Passes in small numbers along the mountains of Seuen-hwa-foo (David). 
518. Grus viridirostris, Vieill.; P. Z. S. 1863, p. 309, 1870, p. 428.

Antigone montignesia, Bp. Consp. Av. p. 100.

Brought to market for sale at Shanghai and at Pekin.

519. Grus leucogeranus, Pall.

Breeds in the province of Leantung (David).

520. Grus virgo, L.; Ibis, 1867, p. 413.

Abundant in spring and autumn at Seuen-hwa-foo. Breeds in Mongolia (David).

521. Glareola orientalis, Lath.; Ibis, 1861 , p. 342,1863 , p. 404 ; P. Z. S. 1863 , p. 309.

Tientsin; Formosa.

522. Vanellus cristatus, Mey. \& Wolf; Ibis, 1861 , p. 342 , 1865 , p. 349 , 1867, p. 399 ; P. Z. S. 1863 , p. 309.

Wanders down as far south as Canton and into Formosa in winter. Breeds in Mongolia (David).

\section{Chettusia cinerea.}

Lobivanellus cinereus, Blyth, P. Z. S. 1863, p. 309.

Lobivanellus inornatus, Schleg. F. J. ; Ibis, 1860, p. 359.

From the banks of the Yangtsze to Pekin. Mongolia (David).

524. Hoplopterus ventralis (Cuv.); Ibis, 1870, p. 361 .

\section{Hainan.}

525. Squatarola helvetica (L.); Ibis, 1860, p. 63, 1861, pp. 51,342 , 1863, p. 404 , 1870 , p. 360 ; P. Z. S. 1863 , p. 309.

Down the coast in winter.

526. Charadrius fulvus, Gm.

Charadrius longipes, Temm.; Ibis, 1863, p. 404, 1870, p. 360 ; P. Z. S. 1862 , p. 319 , 1863 , p. 309.

Charadrius virginicus, Ibis, 1860 , p. 358,1861 , pp. 51, 342, 1862, p. 254.

Charadrius pluvialis, Ibis, 1862, p. 307.

Throughout China and Formosa; Hainan.

527. Eudromias veredus (Gould).

Agialites veredus, P. Z. S. 1870, pp. 141, 430.

Charadrius veredus, Gould, P. Z. S. 1848, p. 38.

Shanghai and Australia (Gould); Macassar (Wallace). Procured at Pekin by Père David. 
528. ÆGialites Geofrroyi (Wagler); Ibis, 1861, p. 51, 1863, p. 405 , 1870 , p. 360 ; P. Z. S. 1870 , p. 141 .

Egialites leschenaultii, Ibis, 1861, p. 342, 1862, p. 255 ; P. Z.S. 1863, p. 309.

China coast in winter; Formosa.

529. Ægialites mongolus (Pall.); Swinh. P. Z. S. 1870, p. 140.

Egialites mongolicus, Swinh. Ibis, 1870, p. 360 ; P. Z. S. 1863, p. 310 .

Hiaticula inornata, Gould, B. of Austr. vi. pl. 19.

China coast in winter.

530. Ægialites hartingi, Swinh. P. Z. S. 1870 , p. 136 , pl. 12.

Flats of the Upper Yangtsze (Szechuen) in spring.

531. Egialites cantianus (Lath.); Ibis, 1860, p. 63, 1861, pp. 51 , 342 ; P. Z. S. 1863 , p. 310,1870 , p. 138.

China coast in winter.

532. Egialites dealbatus, Swinh. P. Z. S. 1870, p. 138; Ibis, 1870 , p. 361 .

Egialites cantianus, Ibis, 1860, p 429, 1863, p. 405.

Resident on the coasts of South China and Formosa.

533. Ægialites hiaticula (L.)?

Charadrius longipes, David, Nouv. Arch. 1867, Bull. p. 38.

"Close to C. hiaticula, but with longer legs; I obtained a single specimen of this in winter at Pekin" (David).

534. Fgialites dubius (Scop.).

Ėgialites philippinus, Ibis, 1862, p. 255, 1863, p. 406; P. Z.S. 1863 , p. 310.

Agialites curonicus, P. Z. S. 1870, p. 137.

Egialites intermedius, Ibis, 1870, p. 361.

Ayialites pusillus, Ibis, 1860, p. 63, 1861, p. 51.

Charadrius philippinus, Ibis, 1861, pp. 260, 342.

Throughout South China, Formosa, and Hainan in winter; breeds in North China (Talien Bay). Chinese birds agree with the European. The race found in Bengal is smaller, and is probably the $\mathscr{E}$. minutus (Pall.). E. intermedius (Ménétriés) appears to be a lesser form of E. hiaticula (L.) with more slender bill, which sometimes occurs in England, and is considered by many to be merely the latter species not fully developed. $\mathbb{E}$. pusillus (Horsf.) of Java and $\boldsymbol{E}$. philippinus (Lath.) of Luzon I take to be the same as our bird; as being only winter visitants to the archipelago, they would naturally be the species that passes our coast in spring and autumn. 
535. Hematopus osculans, $n$. sp.

Hamatopus ostralegus, Swinh. Ibis, 1860, p. 63, 1861, pp. 261, 342.

Hamatopus longirostris, Swinh. Ibis, 1863, p. 406 ; P. Z. S. 1863, p. 310 .

On drawing up my last list and on finding our bird to be different from the European species, I set it down as $H$. longirostris, Gray, without, however, comparing specimens. Prof. Schlegel (Mus. des Pays-Bas) draws attention to my mistake, but identifies the bird with H. ostralegus. On careful comparison I find it intermediate. It has white on its primary quills, but not to such an extent as in $H$. ostralegus; and it has the long bill and black tips to its white upper tail-coverts as in $H$. longirostris, but the tip-spots are smaller. Thus holding an intermediate position between the two, it is impossible to class it with either species, and I would propose to separate it as above.

Characters.-First three rectrices with black shafts, the fourth showing a little white, which increases and expands on the quills that follow (in $H$. ostralegus the white commences on the first quill, and in $H$. longirostris the shafts are all black). The upper tailcoverts that overlap the tail tipped with black (pure white in $\boldsymbol{H}$. ostralegus). Bill, from the forehead, $3 \cdot 6$ inches. These characters are taken from an adult male shot in Talien Bay in July. An immature bird shot in November at Swatow shows the same long bill, small extent of white on the wing, and dark tips to the extreme uropygials, but its dark parts are brown instead of black. Neither specimen has the white collar. This Oyster-catcher breeds in North China (Talien Bay), and wanders down the coast in winter as far, at least, as Swatow.

536. Recurvirostra avocetta, L.; Ibis, 1860, p. 66, 1861, p. 343, 1863, p. 406 ; Zoologist, 1860, p. 7103 ; P.Z.S. 1863, p. 311.

Recurvirostra sinensis, Ibis, 1867 , p. 401.

China coast in winter. "Is found in May at Ordo near the Yellow River” (David).

537. Himantopus Candidus, Bonnaterre; L.

Himantopus melanopterus, Temm.

One seen at Pekin by Père David (Catalogue).

538. Totanus glottis, L. ; Ibis, 1863, p. 406, 1870, 364 ; P.Z.S. 1863, p. 311 .

Totanus glottoides, Vig.; Ibis, 1860, p. 66, 1861, p. 343.

Totanus glottis, Ibis, 1862, p. 254.

General in winter.

539. Totanus stagnatilis, Bechst.; Ibis, 1862, p. 254, 1863, p. 406,1870 , p. 364 ; P. Z.S. 1863 , p. 311 .

Formosa ; Amoy ; Hainan. 
540. Totanus fuscus, L. ; Ibis, 1862, p. 254, 1863, p. 97 ; P. Z.S. 1862, p. 319,1863 , p. $311,1870,427$.

Canton; Tientsin; Shanghai.

541. Totanus caliddis, L. ; Ibis, 1861 , p. 343, 1862, p. 254, 1863 , p. $407,1865,347,1870$, p. 364 ; P. Z. S. 1862 , p. 320 , 1863 , p. 311 .

Totanus fuscus, Ibis, 1866, p. 295.

General in winter.

542. Totanus Glareola, L. ; Ibis, 1860 , p. 66,1861 , p. 343 , 1863 , p. 407 , 1870, p. 363 ; P.Z.S. 1863 , p. 311.

Totanus affinis, Horsf.; Ibis, 1866, p. 294 ; P. Z. S. 1863, p. 311. Hurries past in early autumn, and returns late in spring.

543. Totanus ochropus, L.; Ibis, 1860 , p. 66, 1861, p. 343 , 1862 , p. 254, 1863, p. 407 , 1870, p. 363 ; P.Z.S. 1863 , p. 312.

Throughout China and Formosa.

544. Totanus incanus, Vieill. N. D. d'H. N. vi. p. 400.

Totanus brevipes, Vieill. l.c. p. 410 ; Ibis, 1863, p. 407, 1867, p. 390 ; P. Z. S. 1863 , p. 312.

Totanus pulverulentus, M. \& S. ; Ibis, 1860, pp. 132, 359, 1861, p. 343,1862 , p. 254.

Chinese and Formosan coasts in winter.

545. TRINGoides hypoleucus (L.) ; Ibis, 1860 , p. 66,1861 , p. 343,1862 , p. 259,1863 , p. 408,1870 , p. 363 ; P.Z.S. 1863 , p. 312 .

Throughout China, Formosa, and Hainan.

546. Terekia cinerea (Gmel.); Ibis, 1863, p. 97 ; P. Z. S. 1863, p. 312.

Terekia javanica, P. Z. S. 1862, p. 319.

Tientsin (Fleming).

547. Lrmosa uropygialis, Gould; Ibis, 1863, p. 409, 1870, p. 362 ; P. Z.S. 1863 , p. 312.

Limosa lapponica seu rufa, Ibis, 1861, p. 410, 1863, p. 97, 1867, p. 388.

Amoy, Formosa, and Hainan, in winter. Breeds in Amoorland and Alaska; wanders during our cold season to the Malay archipelago, Australia, and New Zealand.

548. Limosa Brevipes, G. R. Gray, Brit. Mus. Cat. Gralla, p. 95 .

Limosa melanuroides, Gould.

Limosa melanura, Ibis, 1868 , p. 58 ; P. Z. S. 1863 , p. 313.

One specimen procured at Amoy on the 30th of April, 1867, in 
partial summer plumage. Probably breeds in Amoorland, if not in Japan also, ranging in winter to Borneo, the Moluccas, Australia, and New Zealand. The European L. agocephala (L.) is the winter species in India.

549. Pseudoscolopax semipalmatus, Jerdon, P. Z. S. 1863 , p. 313 .

Micropalama tacsanowskia, J. Verr.

Teintsin; Hankow ; Trans-Baikal (J. Verreaux); India (Blyth and Jerdon); Borneo (Schlegel).

550. Scolopax Rusticula, L. ; Ibis, 1860 , p. 66,1861 , pp. 56 , 343, 1863, p. 415 ; P. Z. S. 1863 , p. 313.

Throughout China in winter.

551. Gallinago solitaria, Hodgs. J. A. S. vi. p. 491; P. Z. S. 1863, p. 313.

Pekin (David). Specimens from South China, previously referred to this, belong to the following species.

552. Gallinago megala, Swinh. Ibis, 1861, p. 343, 1862, p. 255, 1863, p. 415 , 1865 , p. 232 ; P.Z. S. 1863 , p. 313.

Gallinago solitaria?, Ibis, 1860 , pp. $66,132,359,1864$, p. 370 , 1865 , p. 355, 1866, pp. 134, 294, 1867, p. 233.

Gallinago stenura, Radde, Reise, Taf. xiii.

Throughout China and Formosa in seasons of migration. I have seen specimens from Lake Baikal.

553. Gallinago horsfieldi (Gray); Zool. Misc. p. 2.

Gallinago stenura (Bp.); Ibis, 1860, p. 66, 1861, pp. 56, 343, 1862 , p. 259 , 1863, p. 415 , 1865, p. 232, 1867, p. 234, 1870, p. 362 ; P. Z. S. 1863 , p. 314 .

Gallinago biclava, Hodgs.

Gallinago heterocerca, Cab.

Throughout China, Hainan, and Formosa in winter. Probably goes north to breed; specimens have been sent from Lake Baikal.

554. Gallinago scolopacina, Bp.; Ibis, 1863, p. 415, 1865, p. 347,1867 , p. 234 , 1870 , p. 362 ; P.Z.S. 1863 , p. 314 .

Gallinago burka, Swinh. Ibis, 1865, p. 231; P. Z. S. 1863, p. 314.

Gallinago uniclava, Hodgs. ; Ibis, 1860, p. 66, 1861, pp. 56, 343, 1862, p. 259.

Gallinago media, Ibis, 1866, p. 294.

China, Formosa, and Hainan, in winter.

555. Limnocryptes Gallinula (L.).

Gallinago gallinula, P. Z.S. 1863, p. 314.

I have never seen this bird in China. One specimen was pro- 
cured by a sporting friend in Formosa, and he sent it to me as the only one he had ever met with in our part of the world.

556. Rhynchea bengalensis (L.); Ibis, 1865, pp. 230, 347, 1866 , p. 137,1870 , p. 362 ; P. Z. S. 1863 , p. 314.

Rhunchaea sinensis, Lath. Ibis, 1864, p. 370, 1867, p. 404.

Rhynchrea orientalis, Horsf.

Rhynchops sinensis, Ibis, 1861, p. 267.

Throughout China and Formosa in summer. I find that Painted Snipes from Africa have the chin bare, which is not the case with specimens from India and China. R. capensis (Gmel.) may therefore rank as a distinct species.

557. Calidris arenaria (L.); Ibis, 1860 , p. 359, 1861, p. 342, 1863 , p. 414,1870 , p. 363 ; P. Z.S. 1863 , p. 315.

General in winter.

558. Strepsilas interpres (L.) ; Ibis, 1860, p. 359, 1861, p. 342 , 1862 , p. 255,1863 , p. 414,1870 , p. 361 ; P.Z.S. 1863 , p. 315 ; Zoologist, 1860, p. 7103.

559. LoBIPES HYPERBOREUS (L.); Ibis, 1861 ,p. 412, 1863,p. 415, 1865 , p. 358 , 1870 , p. 363 ; P. Z. S. 1863 , p. 315 ; Zoologist, 1861, p. 7643 .

560. Tringa tenuirostris (Horsf.); P. Z. S. 1863, p. 315.

Totanus crassirostris, T. \& S. Faun. Jap. lxiv.

Schœiclus magnus, Gould, B. of Austr. vi. pl. 33.

561. Tringa Canutus, L.; P. Z. S. 1863, p. 315.

Procured at Shanghai.

562. Tringa platyrhyncha, Temm.; Ibis, 1862 , p. 255,1863 , p. 412,1870 , p. 363 ; P.Z.S. 1863 , p. 316 .

Limicola pygmaa, Midd. Sib. Reise.

China and Formosa in winter. The Tringa pygmaa of Latham, as Prof. Newton has proved to me, is based on T. subarcuata, and the name ought not to be applied to this species.

563. Tringa cinclus, var. chinensis.

Tringa chinensis, Gray, Zool. Misc. p. 2 ; Ibis, 1862, p. 255.

Tringa cinclus, Ibis, 1860, p. 66, 1861, p. 412, 1863, pp. 97, 411; P. Z. S. 1863 , p. 316 .

Tringa subarquata, Ibis, 1861, p. 342.

Tringa alpina, Ibis, 1866, p. 136, 1870, p. 363 .

In length and thickness of bill surpassing $T$. cinclus, var. americana, Baird, with longer toes. In summer dress remarkable for the big black blotches on its breast, and for the blackness and want of wufescence of its upper parts. 

late.

Chinese and Formosan coasts in winter, coming early and retiring

564. Tringa acuminata (Horsf.); Ibis, 1863, p. 412 ; P. Z.S. 1863 , p. 316 .

Tringa —?, Ibis, 1861, p. 342 .

Tringa pectoralis, Ibis, 1863 , p. 97.

Passes our coasts early, and returns late.

565. Tringa damacensis (Horsf.); Ibis, 1863, p. 413 ; P.Z.S. 1863 , p. 316.

Tringa, sp., Ibis, 1860 , p. 359,1861 , p. 342 .

Tringa subminuta, Midd. Sib. Reis. p. 222, t. xix. f. 6 ; Ibis, 1862, p. 255,1863 , p. 97.

Passes our coasts early and returns late.

566. Tringa salina, Pall. It. iii. p. 700.

Tringa ruficollis, Lath. Av. v. p. 183.

Tringa albescens, Temm. Pl. Col. 41. fig. 2 ; Ibis, 1863, p. 413, 1870, p. 363 ; P.Z.S. 1863, p. 316.

Tringa minuta, Ibis, 1860, pp. 342, 358, 1862, p. 255.

The eastern representative of $T$. minuta. Passes the China coast early, and returns late, on its winter migration. All my specimens are of this race; but $I$ have seen the true $T$. minuta, in summer plumage, from Lake Baikal. Mr. Gould reports its breeding in Australia (Hand-b. B. of Austr. ii. p. 258)!

567. Tringa subarcuata, L.; P. Z. S. 1862, p. 319,1863 , p. 317 .

Procured in Amoy and Formosa, in partial summer dress, in the middle of May. Tientsin (Fleming).

568. Tringa temminckir, Leisl.; Ibis, 1860 , p. 66,1861 , p. 342 , 1862 , p. 255,1863 , p. 412 ; P.Z.S. 1863 , p. 317.

Throughout China in winter.

569. Eurinorhynchus pygmeus (L.).

Eurinorhynchus orientalis, Blyth, Ibis, 1867, p. 234.

Procured once at Amoy.

570. Numenius minutus, Gould, P. Z. S. 1840, p. 176, 1863, p. 317 .

Numenius minor, Müll. \& Schleg. Verh. Nat. Gesch. p. 110 ; Ibis, 1861, p. 411, 1863, p. 409.

Amoy. Received also from Trans-Baikal, so that it probably goes south to India, and will be the N. arcuatulus, Hodgs., of Nepal, Schlegel has it from Amboina (Mus. des Pays-Bas), and Gould from New South Wales. It passes our coast early, and returns late. $\mathrm{Mr}$. Gould met with the bird on the 4th April (Handb. B. Austr. ii. 
p. 280). Leaving Australia a few days later, there is no reason why these birds should not pass by the Moluccas, and onwards along the China coast in time to nidificate in Amoorland in June.

571. Numenius pheopus (L.); P.Z.S. 1863, p. 317.

Pekin to Shanghai in winter.

572. Numenius Luzoniensis (Gmel.), Syst. Nat. 1788, i. p. 656. Numenius atricapillus, Vieill.

Numenius uropygialis, Gould, P. Z. S. 1840, p. 175 ; Ibis, 1863, p. 409,1866 , p. 137 .

Formosa; South China coast. Throughout the islands to Australia. Breeds in southern latitudes.

573. Numenius lineatus, Cuv. Règn. An. 2nd ed. i. p. 52, note 2 ; Blyth, Ibis, 1867 , p. 167.

Numenius major, T. \& S. Faun. Jap. pl. lxvi.; Ibis, 1860, p. 66, 1863 , p. 410 , 1867 , p. 391,1870 , p. 363 ; P.Z.S. 1863 , p. 318.

Numenius arcuatus, T. \& S. Faun. Jap.; Swinh. Ibis, 1863, p. 410 ; P.Z.S. 1863 , p. 318 .

Numenius cassinii, Swinh. Ibis, 1867, p. 398 ; P. Z. S. 1863, p. 317 .

The long-billed $N$. major is the female, and the shorter-billed socalled $N$. arcuatus is the male ; and $N$. cassinii is a small variety of the same species, at once distinguishable from $N$. arcuatus of Europe by its white unspotted axillaries. On the China coast the long-billed birds often associate with the short bills, and, as Prof. Schlegel observes (Mus. des Pays-Bas), are of similar plumage. I have examined a number of both, and in every case I have found the long-bills females and the short-bills males. I am therefore convinced that they are mere sexes of the same species. Prof. Schlegel points out the same birds occurring on the coast of South Africa, where they have been also set apart as distinct species. I have compared a specimen from South Africa, kindly given me by Mr. R. B. Sharpe; and it tallies completely with our male birds from China. It follows, then, that the winter Curlew of India will be the same, and that this migration is another instance of that exemplified in the case of Erythropus amurensis, Radde, of a North-east-Asian bird passing through India to Africa in winter.

It spreads down the Chinese and Formosan coasts, during the cold season, as far south as Hainan, extending, according to Schlegel (Mus. des Pays-Bas), to Borneo and Java.

574. Numenius tahitiensis (Gmel.); Swinh. P. Z. S. 1863, p. 318 .

Numenius cyanopus, Vieill. 2nd ed. du Nouv. Dict. d'Hist. Nat. viii. p. 306 .

Numenius major, Faun. Jap. (in part); Ibis, 1861, p. 343.

Numenius australis, Ibis, 1863, p.97; P.Z.S. 1863, p. 318. 
Numenius rufescens, Gould, P.Z.S. 1862, p. 286 ; B. of As. pl. ; Ibis, 1863, p. 410 (summer); P. Z.S. 1863, p. 318.

Breeds in Amoorland; common near Pekin in August ; found, during the season of migration, in Japan, Formosa, Moluccas, Australia, Tasmania, and the Society Islands. Not yet noticed on South-China coast.

575. IBIDORHYNChUS STRUThersi, Vigors.

Ardea —?, Ibis, 1861, p. 344 .

"Frequents the banks of the most solitary fish-containing streams of the mountains near Pekin, where it sometimes breeds" (David).

576. Ibis Propinqua, Swinh. P.Z. S. 1870, p. 428

Threskiornis melanocephalus?, P. Z. S. 1863, p. 318.

Talienwan; Canton river.

577. Ibis Nippon, T. \& S. Faun. Jap.; Ibis, 1863, p. 416, 1867, p. 413,1870 , p. 365 ; P.Z.S. 1863 , p. 318.

China coast in winter, as far south as Hainan.

578. Ibis falcinellus, L.

Seen on the lakes between Shanghai and Ningpo.

579. Platalea major, Temm. \& Schl.; Ibis, 1863, p. 417 , 1864, pp. 364, 370 ; P.Z.S. 1863, p. 319.

Platalea leucorodia, Ibis, 1860, p. 65, 1861, p. 344.

Formosa ; Swatow.

580. Tantalus leucocephalus, Gmel. Syst. Nat. i. p. 649.

Tantalus longimembris, Swinh. Ibis, 1867, pp. 227, 232.

Procured at Amoy.

581. Leptoptilus Javanicus (Horsf.); Ibis, 1870, p. 364 .

Hainan.

582. Ciconia alba, Linn.; P. Z. S. 1863, p. 319.

Père David saw it on one occasion, in November, at Takoo, mouth of the Peiho river.

583. Ciconia nigra, Linn.; Ibis, 1866, p. 401 ; P. Z. S. 1863 , p. 319.

"Inhabits, in small numbers, the mountains near Pekin that yield streams containing fish; nests on the most inaccessible rocks"' (David).

584. Ardea cinerea, L.; Ibis, 1860, p. 63, 1861, pp. 51, 343, 1863 , p. 417 , 1870 , p. 365 ; P.Z.S. 1863 , p. 319.

Throughout China, Hainan, and Formosa.

585. Ardea purpurea, L.; P. Z. S. 1863, p. 319.

Hankow (Central China). 
586. Egretta modesta (Gray).

Ardea modesta, J. E. Gray, Zool. Misc. p. 19 ; Ill. Ind. Zool. pl. 49.

Ardea syrmatophora, Gould, P. Z. S. 1846 ; B. of Austr. pl.

Ardea egretta?, Ibis, 1860 , p. 64,1861 , p. 51.

Herodias alba, Ibis, 1863 , p. 417,1866 , p. 295,1867 , p. 387 , 1870 , p. 365 ; P. Z. S. 1863 , p. 319 , 1870 , p. 427.

Prof. Schlegel (Mus. des Pays-Bas) maintains that the $E$. alba of Europe is constantly of a larger form than the White Heron of Africa, Asia, and Australia; but he identifies the latter with the American White Heron, A. egretta, Gmel. (leuce, Illiger). I have compared an adult male from Canton with an adult male from America in Mr. Salvin's collection. The Chinese bird has a tarse $\frac{5}{8}$ inch longer than the American, but is otherwise of nearly similar proportions; it has a more compressed head, a black bill, and a considerably longer dorsal train. Mr. Salvin says that he has never heard of the American bird acquiring a black bill, and agrees with me in considering it distinct from the East-Asian bird. With the African E. favirostris, Temm., I have not been able to make comparison. The European $E$. alba, like our bird, has the bill yellow in winter, black in summer, and would appear to be a larger edition of the same, in fact a larger conspecies. In the same way the Californian White Heron seems to be a larger conspecies of the $E$. leuce of South-eastern North America. There is no harm in recognizing them as species. Throughout China, Hainan, and Formosa.

587. Egretta intermedia (V. Hasselq.).

Herodias intermedia, Ibis, 1861 , p. 344 ; P. Z. S. 1863, p. 319 , 1870 , p. 427.

Herodias egrettoides, Ibis, 1861, p. 261.

Bill yellow throughout the year, tipped with black. Canton; Hankow.

588. Garzetta egretta (Brisson).

Herodias garzetta, Ibis, 1860 , pp. $64,429,1861$, p. 52, 1862, p. 258,1863 , p. 417,1870 , p. 365 ; P. Z. S. 1863 , p. 319,1870 , p. 427 .

Southern China, Hainan, and Formosa.

589. Garzetta eulophotes.

Herodias eulophotes, Swinh. Ibis, 1860, p. 64, 1863, p. 4i8; P. Z. S. 1863 , p. 320 .

Amoy; North Formosa.

590. BubulCus Coromandus.

Buphus coromandus (Bodd.), Ibis, 1860, p. 64, 1861, p. 52, 1862, p. 258,1863 , p. 419 , 1865 , p. 234 ; P.Z. S. 1863 , p. 320.

Summer visitant to South China and Formosa. 
591. Butorides Javanicus (Horsf.) ; Ibis, 1860, pp. 132, 358, 1861, p. 52 ; P. Z. S. 1863 , p. 320.

Herodias asha, Ibis, 1860, p. 64.

Comes to South China in summer to breed.

592. Butorides macrorhynChus, Gould.

Butorides javanicus, Ibis, 1863, p. 420.

A larger bird than the last in all its proportions, but otherwise very similar. Common in Formosa in summer. I procured a male at Amoy on the 26th Aug. 1866. It is the species that visits Japan (Schleg. Mus. des Pays-Bas).

593. Ardeola prasinosceles, Swinh. Ibis, 1860, p. 64, 1861, p. 52,1862 , p. 258,1863 , p. 421 (errore), 1870, p. 365 ; P. Z. S. 1863, p. 319.

Resident in South China and westwards to Szechuen. Found as far south as Cochin China. In Siam and Malacea is replaced by the A. malaccensis (Gmel.), A. bacchus, Bp. I entered it in my Formosan list on insufficient evidence. It has not occurred on that island.

\section{Nyctiardea NyCticorax (L.).}

Nycticorax griseus, Ibis, 1860, p. 358,1861 , pp. 53, 56, 344, 1863 , p. 423 , 1866, p. 293 , 1870 , p. 365 ; P.Z.S. 1863 , p. 320.

Nycticorax manillensis?, Ibis, 1860 , p. 65.

Resident throughout China and Formosa.

595. Goisachius melanolophus.

Ardea melanolopha, Raffles, Linn. Trans. vol. xiii. part 2, p. 326. Ardea goisagi (Temm.), Pl. Col. 582 ; Faun. Jap. pl. 75 ; Ibis, 1865, p. 358, 1866, pp. 122, 403.

Nycticorax melanolophus, P. Z.S. 1863, p. 320.

Formosa. Procured also from Japan, the Philippines, Sumatra, Arracan, and Ceylon.

596. Botaurus stellaris, L.; Ibis, 1861 , p. 410 ; P. Z. S. 1863 , p. 320.

Throughout China.

597. Ardetta flavicollis (Lath.); Ibis, 1862, p. 258, 1863 , p. 422 ; P.Z.S. 1863 , p. 320 .

Foochow and Hankow.

598. Ardetta cinnamomea (Gmel.); Ibis, 1860, p. 65, 1861, p. 53 ; 1862 , p. 258,1863 , p. 422 ; P. Z. S. 1863 , p. 320 .

Throughout China and Formosa in summer. 
599. Ardetta sinensis (Gmel.); Ibis, 1860 , p. 65, 1861, p. 53, 1862 , p. 258,1863 , pp. $97,422,1867$, p. 231 ; P.Z.S. 1862 , p. 320,1863 , p. 321 .

China in summer. Rare in Formosa.

600. Porphyrio celestis, Swinh. Ibis, 1868 , p. 59 ; P.Z. S. 1870 , p. 428.

Porphyrio sp.?, Ibis, 1866, p. 298.

Canton ; Amoy.

601. Hydrophasianus Chirurgus (Scop.); Ibis, 1865, p. 541, 1866 , p. 405.

Hydrophasianus sinensis, P. Z. S. 1863, p. 321.

Hankow ; Amoy coast; Formosa. I watched a party of three immature birds on a pool in South Formosa in January. They float lightly on the water, like Phalaropes, but with the tail partly cocked. They rise heavily, and fly with long slow flaps, looking like small white-winged Herons. They alight boldly on the water, and permit close approach. When sitting they look dark and unnoticeable; but the wings once expanded they become conspicuous white objects. Iris chestnut; bill and legs light sea-green.

602. Gallicrex Cristata (Lath.) ; Ibis, 1861, pp. 56, 267, 411, 1863, p. 425, 1866, p. 297 ; P. Z.S. 1863 , p. 321.

South China; westward to Szechuen; Formosa.

603. Gallinula chloropus (L.); Ibis, 1861, p. 56, 1862, p. 307,1863 , p. 427 ; P. Z.S. 1863 , p. 321 .

Throughout China and Formosa.

604. Gallinula pheenicura (Penn.); Ibis, 1863, p. 427, 1870, p. 364 ; P. Z. S. 1863, p. 321.

Porzana phoenicura, Ibis, 1860 , p. 67,1861, p. 57.

South China ; Formosa.

605. Porzana erythrothorax, Temin. \& Schl.; Swinh. Ibis, 1861, pp. 57, 411.

Porzana fusca, Ibis, 1863, p. 426 ; P. Z. S. 1863, p. 321.

Prof. Schlegel (Mus. des Pays-Bas) recognizes this as distinct from $P$. fusca of India. Though variable in size and length of wing, it has longer toes ; and the pectoral red does not extend so low down on the belly as in P. fusca. It is a close conspecies of the Indian bird.

606. Porzana Pygmea (Naumann); P.Z.S. 1863, p. 321.

Gallinula bailloni, Vieill.

Porzana bailloni, Ibis, 1863, p. 97,1867 , p. 389 ; P. Z. S. 1862 , p. 320.

Throughout China in summer. It strikes me that Pallas's name 
minuta must really apply to this bird, the Little Crake of Europe not being found so far eastwards as Dauria ( $c f$. Pall. Zoogr. ii. p. 156).

\section{Rallina mandarina.}

Porzana mandarina, Swinh. Ann. \& Mag. N. H. vol. v. 4th series, p. 173 ; P. Z. S. 1870 , p. 427.

Procured at Canton, in company with $\boldsymbol{P}$. erythrothorax, by $\mathrm{Mr}$. S. Bligh.

608. HYPotenidia striata.

Rallus striatus, L.; Ibis, 1863, p. 427, 1865, p. 234, 1866, p. 394 ; P. Z.S. 1863 , p. 321 .

Formosa; Canton (Schlegel, Mus. des Pays-Bas).

609. Rallus indicus, Blyth, J.A. S. xviii. p. 820 ; Ibis, 1863, p. 97 ; P. Z.S. 1862 , p. 320 .

Rallus aquaticus, P.Z.S. 1863, p. 322.

The Asiatic representative of $\boldsymbol{R}$. aquaticus of Europe, distinguishable by its dark facial streak from the base of the bill to beyond the eyes. Tientsin.

610. Fulica Atra, L. ; Ibis, 1861 , p. 344,1864 , p. 370,1865 , p. 349 , 1867 , p. 397 ; P.Z.S. 1863 , p. 322 .

China; Formosa.

611. Podiceps philippensis (Bonn.); Ibis, 1860, p. 67, 1870 , p. 366.

Podiceps minor (Gmel.); Ibis, 1863, p. 433, 1865, p. 541 ; P. Z. S. 1863, p. 322 .

Podiceps philippinus, Ibis, 1861, p. 343.

China; Formosa; Hainan.

612. Podiceps auritus (L.); Ibis, 1860, p. 67, 1861, p. 344 ; P. Z. S. 1863, p. 322.

Amoy in winter.

613. Podiceps connutus (Gmel.); P. Z. S. 1863, p. 322.

Colymbus cornutus, Gmel. Syst. Nat. i. p. 591.

Amoy in winter.

614. Podiceps cristatus (L.); Ibis, 1860 , p. 67, 1861, p. 344 ;

P.Z.S. 1863, p. 322.

Podiceps cornutus, Pall.

To the south coast, in winter, in large numbers.

615. Colymbus septentrionalis, L.; Ibis, 1863, p. 433; P.Z.S. 1863, p. 322 .

Colymbus glacialis, Ibis, 1860, p. 67, 1861, pp. 268, 410, 345 .

Common winter visitant to the south coast. 
616. Mergellus albellus (L.); Ibis, 1861 , p. 344 ; P. Z. S. 1863 , p. 322 .

North China. Common on the Yangtsze in winter.

617. Mergus Serrator, L.; P. Z. S. 1863, p. 323.

Mergus serratus, Ibis, 1860, p. 67, 1861, p. 344.

Throughout China.

618. Mergus castor, L.

Mergus merganser, L.; Ibis, 1861, p. 344 ; P. Z.S. 1863, p. 323.

Comes down as low as Amoy in winter.

619. Mergus squamatus, Gould, P.Z. S. 1864, p. 184.

China (Gould).

620. Cygnus musicus, Bechst.; Ibis, 1862 , p. 254 ; P. Z. S. 1863 , p. 323.

Shanghai market in winter.

621. Cygnus minor, Pall. Zoogr. ii. p. 214 ; Ibis, 1861, p. 344, 1862, p. 254 ; Zoologist, 1860, p. 6924 ; P. Z.S. 1863, p. 323.

Cygnus bewickii, Yarr.; Ibis, 1867, p. 398.

Shanghai market in winter.

622. Cygnus davidi, Swinh. P.Z. S. 1870, p. 430.

Smaller than the last, with orange-red bill and legs. "Lores covered with small feathers" (David). The specimen on which this species is based is in the Pekin Museum, and was procured by Père David in the market at Tientsin.

623. Anser Cygnoides (L.) ; Faun. Jap. pl. ; Ibis, 1861, p. 344 ; P.Z.S. 1863, p. 323 .

Common in the Shanghai market in the early part of winter.

624. Anser albifrons (Gmel.); Ibis, 1861, p. 344 ; P. Z. S. 1863 , p. 323 .

Shanghai market in winter.

625. Anser erythropus, L.

Anser minutus, Naumann.

In the market at Kinkiang, on the Yangtsze, on the 16th March, 1869.

626. Anser cinereus, Meyer, var. rubrirostris.

Anser ferus, Swinh. Ibis, 1861, p. 344,1862 , p. 254 ; P. Z. S. 1863 , p. 323,1870 , p. 427.

Anser rubrirostris, Hodgs.

Shanghai in winter. I have one shot at Canton by Mr. S. Bligh. It is of large form, with long and large bill, white on the frontal 
feathers at the base of the bill, of a pale colour with blotches of black on the underparts, and with very little grey on the wingcoverts and rump. The size of the bill varies greatly in English specimens; but the pale colour, comparative absence of grey, and white frontal edging to the bill seem characteristic of the Eastern race, and $\mathrm{I}$ think it as well to distinguish it as a variety.

\section{ANSER SEgETUM, var. SERRIROSTRIS.}

Anser segetum, Ibis, 1860 , p. 67,1861 , p. 344,1862 , p. 253 , 1867 , p. 392 ; P.Z.S. 1863 , p. 323.

Anser serrirostris, Gould, MS.

A Bean-Goose comes down in immense swarms every cold weather to the marshes, at the river's mouth, near Amoy. They are of large size, and peculiar in having huge bills approximating that of A. grandis. I have handled several, and they were all so distinguishable. I have brought home a male and compared it with a home-shot bird kindly lent me by Mr. Tristram. The Chinese bird has a paler cheek and throat, a much lighter and yellowish-brown neck, narrower white edges and tips to the tail-feathers, and longer tarsi ; but in other respects it is similar. The British Museum has two specimens of this Goose from Trans-Baikal, and Mr. Gould a specimen from Shanghai. Mr. Gould's specimen is labelled $A$. serrirostris, a name he intended to publish in 1862 . On the Wanchow river all the Geese shot by our party on the 10th of February were of this race.

628. Anas boschas, L.; Ibis, 1861, p. 344, 1862, p. 254.

A winter Duck in South China.

629. Anas zonorhyncha, Swinh. Ibis, 1866, p. 394 ; P. Z. S. 1870 , p. 427.

Anas pocilorhyncha, Temm. \& Schl. Faun. Jap. pl. lxxxii.

Throughout China. I believe it breeds in many parts, north and south. It is absurd, with our present experience, to imagine this bird a cross between $A$. boschas and $A$. poeilorhyncha of India. It is a very common Duck at Shanghai, and I have seen many specimens. $A$. pæecilorhyncha does not occur with us; and can we suppose that India would originate a bird to disperse throughout more Eastern Asia, and not reserve any of the hybrids for herself ? Our bird (male) has a narrower yellow nib to the bill, and no basal yellow. It has a distinct white supercilium; throat unspeckled white; alar speculum deep blue, slightly tinged with green; lesser coverts, overlapping the speculum, brown, tipped with black with no white; tertials only slightly margined with white; rump, upper tail-coverts, and tail deep blackish brown, without any bronze reflections; crown, streak through the eye, and short moustache-streak deep brown; cheeks and neck brownish white, with brown specks; breast light yellowish brown, with deep-brown spots ; rest of underparts deep brown, becoming nearly black on the under tail-coverts;

Proc. Zool. Soc.-1871, No. XXVII. 
axillaries pure white. Size about that of A. poecilorhyncha. The female is smaller than the male, and has the blotched yellowish of the breast extending to the abdomen. In $A$. poecilorhyncha the breast and belly are nearly white, covered with round brown spots. The speculum of our bird is greener in some specimens; and some show a little white on the overlapping wing-coverts in rear of their black tips, and have more or less white on the outer webs of the tertials.

630. Tadorna cornuta (Gmel.).

Tadorna vulpanser, Flem.; Ibis, 1861, p. 344, 1862, p. 254. Anas cornuta, S. G. Gmel. It. ii. p. 185.

China coast in winter.

631. Casarca rutila (Pall.); Ibis, 1861, p. 344, 1862, p. 254. Common, in winter, on inland waters; rare on the coast.

632. Spatula clypeata (L.).

Rhynchaspis clypeata, Swinh. Ibis, 1861, p. 57, 1862, p. 254, 1867, p. 388 .

Abundant in South China and Formosa in winter.

633. Dafila acuta (L.) ; Ibis, 1861, p. 345, 1867, p. 399.

China and Formosa in winter.

634. Mareca penelope, L. ; Ibis, 1861, p. 345 , 1867, p. 399 , 1870 , p. 366.

Abundant in South China and Formosa in winter.

635. Chaulelasmus streperus (L.).

Procurable in the Shanghai market in winter, but rare.

636. Querquedula crecca (L.); Ibis, 1861, p. 345, 1865, p. 347,1867 , p. 399,1870 , p. 366 .

Abundant everywhere in China and Formosa during winter. This species, the Wigeon, and the Shoveller are the commonest winter Ducks in South Formosa.

637. Querquedula circia (L.) ; Ibis, 1863, p. 434, 1867, p. 407 ; P. Z. S. 1870 , p. 427.

Probably breeds in South China, but is rare. Has oceurred also in Formosa.

638. Aix galericulata (L.); Ibis, 1866, p. 295; P. Z. S. 1863 , p. 324 .

I think, throughout China, breeding in many localities. Found also resident in the interior of Formosa.

639. Eunetta formosa (Georgi); Ibis, 1867, p. 394.

Anas glocitans, Pall.; Ibis, 1861, p. 344, 1867, p. 231, 409.

Abundant throughout China in winter. 
640. Eunetta falcata (Pall.).

Anas falcaria, Lath.; Ibis, 1861, p. 345, 1862, p. 254.

Querquedula multicolor, Ibis, 1860, p. 67.

Throughout China in winter. Middendorff figures a young male for the female (Sib. Reise, t. xxi.). The female is coloured more as the female of $A$. boschas, with just a glow of pink on its cheeks.

\section{Edemia fusca (L.).}

Very abundant in the Shanghai market.

642. CEdemia americana (Richardson); Ibis, 1863, p. 435 ; P. Z. S. 1863, p. 324 .

Shot on the Yangtsze by Capt. Blakiston. I have sought in vain in the Shanghai market for both this and the true $\mathscr{E}$. nigra (L.).

643. Bucephala clangula (L.).

Clanyula glaucion, Ibis, 1861, p. 345 .

I have procured this in winter as far south as Amoy. Common at Shanghai.

644. Harelda glacialis (L.).

Père David received a specimen of this shot at Takoo, mouth of the Peiho river.

645. Aythya ferina (L.).

Shanghai market in winter.

646. Fulix marila (L.); Ibis, 1861, p. 345, 1862, p. 254.

Down the China and Formosan coasts in winter.

647. Fulix cristata (L.); Ibis, 1861 , p. 345 , 1862, p. 254 , 1867, p. 399.

Comes with the last.

648. Fulix Baeri, Radde, Reise im Süden von Ost-Sib. 1855-59, p. 376 , t. $x v$.

On my cruise up the river Yangtsze we stopped at Kinkiang for a day and a half; and I was fortunate enough to procure an adult male of this species. It was being hawked about in the streets. My specimen answers precisely to Radde's description and figure, and looks very much like a cross between Anas boschas and Fulix cristata, having somewhat the head and breast of the former and the body of the latter. But mine is too exact a copy of Radde's type, which he procured from a party of four of the same, to admit of being considered a hybrid. Bill French grey. Irides light yellow. Legs patched with grey and black. Head and neck black, reflecting deep green; breast deep chestnut; upper parts, wings, and tail deep brown; greater wing-coverts white, tipped with bronzed brown; tertiaries deep bronzed brown, the foremost edged with 
black; primaries brownish white on their inner webs; large loose feathers on the sides of the rump light reddish brown; abdomen splashed with brown.

649. Phalacrocorax carbo (L.); Ibis, 1860, p. 68, 1861, pp. $261,345,1863$, p. 433 , 1867, p. 390,1870 , p. 367 ; P.Z.S. 1863 , p. 324 .

Phalacrocorax filamentosus, Ibis, 1861, pp. 264, 409.

Phalacrocorax capillatus, P.Z. S. 1863, p. 325.

Throughout China and Formosa; in the south only during the winter.

650. Graculus bicristatus (Pall.), Ibis, 1861, pp. 408, 410, 1863, p. 434 ; P.Z.S. 1863, p. 325.

Phalacrocorax colus, Ibis, 1867, p. 395.

Occurs in winter on the China coast.

651. Pelecanus mitratus, Licht. Abh. Ak. Wiss. Berl. 1838, t. 32 ; P.Z. S. 1868 , p. 266, fig. 3.

Pelecanus minor, P. Z.S. 1870, p. 428.

Pelesanus onocrotalus, Ibis, 1865 , p. 352 ; P. Z. S. 1863, p. 325.

I have a specimen from Foochow.

652. Pelecanus philippensis (Gm.).

Pelecanus philippensis, Swinh. Ibis, 1865, p. 111, 1866, p. 297 ; P. Z. S. 1863, p. 325.

Pelecanus crispus, Ibis, 1860, p. 68, 1862, p. 254.

Amoy.

653. Sula fiber (L.).

Sula fusca, Briss. ; Ibis, 1870, p. 367 ; P.Z. S. 1863, p. 325.

Sula sinicadvena, Ibis, 1865, p. 109.

Formosa ; Shanghai.

654. Larus niveus, Pall.; Bp. Consp. Av. ii. p. 224; Ibis, 1863, p. 428,1870 , p. 366 ; P. Z. S. 1863 , p. 325 .

Larus canus, var. major, Midd. Sib. Reise; P. Z. S. 1864, p. 272.

Larus canus, Ibis, 1860, p. 68, 1861, p. 345.

Like the following, but with stronger bill and longer tarse and toes. Visits Amoy harbour in the coldest weather, usually in immature plumage.

655. Larus canus, L.

Much commoner than the last in Amoy harbour in winter, and often in fine adult plumage. Probably breeds in more southerly latitudes than its ally. 
656. Larus Crassirostris, Vieill.; Ibis, 1863, p. 428 ; P. Z. S. 1863 , p. 326.

Larus melanurus, T. \& S. Faun. Jap.; Ibis, 1860, p. 133, 1861, rp. $261,345$.

Larus fuscus, Ibis, 1860, p. 68.

A common winter Gull on the South-China coast.

657. Larus cachinnans, Pall.; lbis, 1863, p. 428, 1870, p. 366 ; P. Z. S. 1863 , p. 327.

Larus argentatus, var. cachinnans, V. Schrenck, Reise Amur., Vög. p. 504.

Larus borealis, Bruch nec Brandt.

Larus argentatus, Ibis, 1861, p. 345.

China coast in winter. Rather larger than $L$. argentatus, with a deeper-coloured mantle.

658. Larus occidentalis, Aud.; P. Z. S. 1863, p. 326.

Larus borealis, Brandt.

A winter visitant to the China coast. Like $L$. argentatus, but of very large size.

659. Chroicocephalus brunneicephalus, Jerdon.

Received at the Paris Museum from Pekin (J. Verreaux).

660. Chroicocephalus ridibundus (L.); Ibis, 1863, p. 428.

Chroicocephalus capisiratus, P. Z. S. 1863, p. 327.

Macao; Amoy. Rare winter visitant to South China.

661. Chroicocephalus saundersi, Swinhoe. See anted, p. 273, Pl. XXII.

662. Sylochelidon Caspia (Pall,); P. Z. S. 1863, p. 328.

Sterna caspia, Pall. ; Ibis, 1860, p. 68, 1861, p. 345, 1863, p. 430, 1870 , p. 366 .

Sterna melanotis, Swainson (winter dress).

China generally.

663. Hydrochelidon hyBRida (Pall.).

Hydrochelidon indica (Steph.); Ibis, 1863, p. 428; P.Z.S. 1863, p. 328.

Sterna leucopareia, Natterer.

Formosa. Not observed yet in China.

664. Hydrochelidon nigra (L.); Ibis, 1863, p. 97 ; P.Z.S. 1863 , p. 328.

Hydrochelidon javanica, Ibis, 1860, p. 68, 1861, p. 345 .

Throughout China. 
665. Thalasseus pelecanoides (King); Schleg. Mus. des Pays-Bas.

Thalasseus cristatus, P. Z. S. 1863, p. 329.

Sterna cristata, Ibis, 1860 , p. 68,1863, p. 430.

Sterna velox, Ibis, 1860, p. 429, 1861, p. 345, 1866, p. 134.

South China ; Formosa, breeds on the islands off its north end.

666. Haliplana anetheta (Scop.).

Sterna panayensis, Gmel. Syst. Nat. 1788, i. p. 607.

Common about the Pescadore Islands.

667. Sterna hirundo, L. ; P. Z. S. 1863, p. 329.

Hankow ; Pekin.

668. ONychoprion Melanauchen (Temm.); Ibis; 1867 , p. 230 , 1870, p. 367.

Sterna minuta?, Ibis, 1860, p. 429.

Common about the rocks outside Amoy Harbour, where they breed.

669. Sternula minuta (L.); Ibis, 1863 , p. 430 ; P. Z.S. 1863, p. 329 .

Sternula sinensis (Gmel.); Ibis, 1863, p. 429 ; P. Z. S. 1863, p. 329.

Sterna minuta, Ibis, 1860 , p. 68,1861 , p. 345 , 1862, p. 307.

Formosa ; China. Breeds on the east coast of Formosa.

670. Gygis alba (Sparrm.).

Sterna.candida, Gmel. Syst. Nat. i. p. 607 ; Ibis, 1864, p. 423.

Seen near the Paracel Shoals in the South-China sea.

671. Anous stolidus (L.); Ibis, 1860, p. 429, 1863, p. 430, 1864, p. 422 ; P. Z.S. 1863, p. 329.

Anous pileatus, North China Asiat. Soc. Journal, May 1859; Ibis, 1869 , p. 360 .

North-east Formosa, where it breeds.

672. Thalassidroma monorhis, Swinh. Ibis, 1867, p. 386.

Amoy. Breeding on the small islands north-east of Formosa (Collingwood).

673. Diomedea albatrus, Pall. Zoogr. ii. p. 308 ; Ibis, 1864 , p. 423.

Diomedea brachyura, Temm.; Ibis, 1860 , p. 67,1863 , p. 431, 1867 , p. 226,1870 , p. 366 ; P. Z.S. 1863 , p. 329.

China Sea.

674. Diomedea Nigripes, Aúdubon; Ibis, 1863, p. 431; P.Z.S. 1863, p. 329.

Diomedea fulginosa, Ibis, 1860, p. 68.

China Sea. 
675. Attagen minor (Gmel.).

Pelecanus minor, Gmel. Syst. Nat. 1788, i. p. 572.

Tachypetes minor, Ibis, 1868, p. 56.

Paracel Shoals. One shot at Amoy.

Note.-In the Chinese Materia Medica (called 'Pun Tsao Kang Muh') I find in the figure of the Fe-seng, or "Flying Beast," a remarkable likeness to the fossil Archaopteryx described by Prof. Owen. I will investigate this question on my present return to China. -R. S.

2. Description of a new Genus of Newts from Western Yunan. By John Anderson, M.D., Curator of the Indian Museum, and Professor of Comparative Anatomy, Calcutta.

[Received April 17, 1871.]

Tylototriton*, n. g.

Head flat, surrounded by a prominent osseous ridge, with a short longitudinal ridge along the vertex. The bony orbit above the eye similar to that of Cynops, Pleurodeles, Euproctus, and Notophthalmus. Parotoids large, auriculoid, flattened from above downwards. Along the body a lateral line of equidistant, large, rounded, knoblike, porous, glandular tubercles, terminating at the root of the tail. The second to the fifth epipleural processes and the extremities of the remaining ribs terminate in the knob-like lateral glands. A broad porous vertebral ridge corresponding to the enlarged crests of the dorsal and sacral vertebræ. An obscure line of pores between the axilla and the groin, and a series of larger ones on the head. Skin finely tubercular. Tail as long as the body, laterally compressed, with sharp lower and upper margins. Limbs well developed. Fingers four, toes five. Palatine teeth begin on a line with the internal nostrils, in two ridges meeting in front, but widely divergent behind. Maxillary teeth small, acute, on the inner edge of the jaw. Tongue of moderate size, suborbicular, adherent, and slightly free at the edges. Vertebræ 46 . Ribs $16: 13$ dorsal, 1 sacral, 2 caudal.

\section{TyLototriton verrucosus, $n$. sp.}

The lateral cranial ridge subtriangular; the median ridge running backwards from the inside of the apex of the triangle, but not reaching so far posteriorly as the lateral ridge, the extremities of which curve inwards like a scroll in front of the parotoids. The parotoids slightly concave above, and somewhat resembling the outline of an upturned human ear. The nostrils close to the extremity of the rounded snout, but with a considerabie interval between them, 


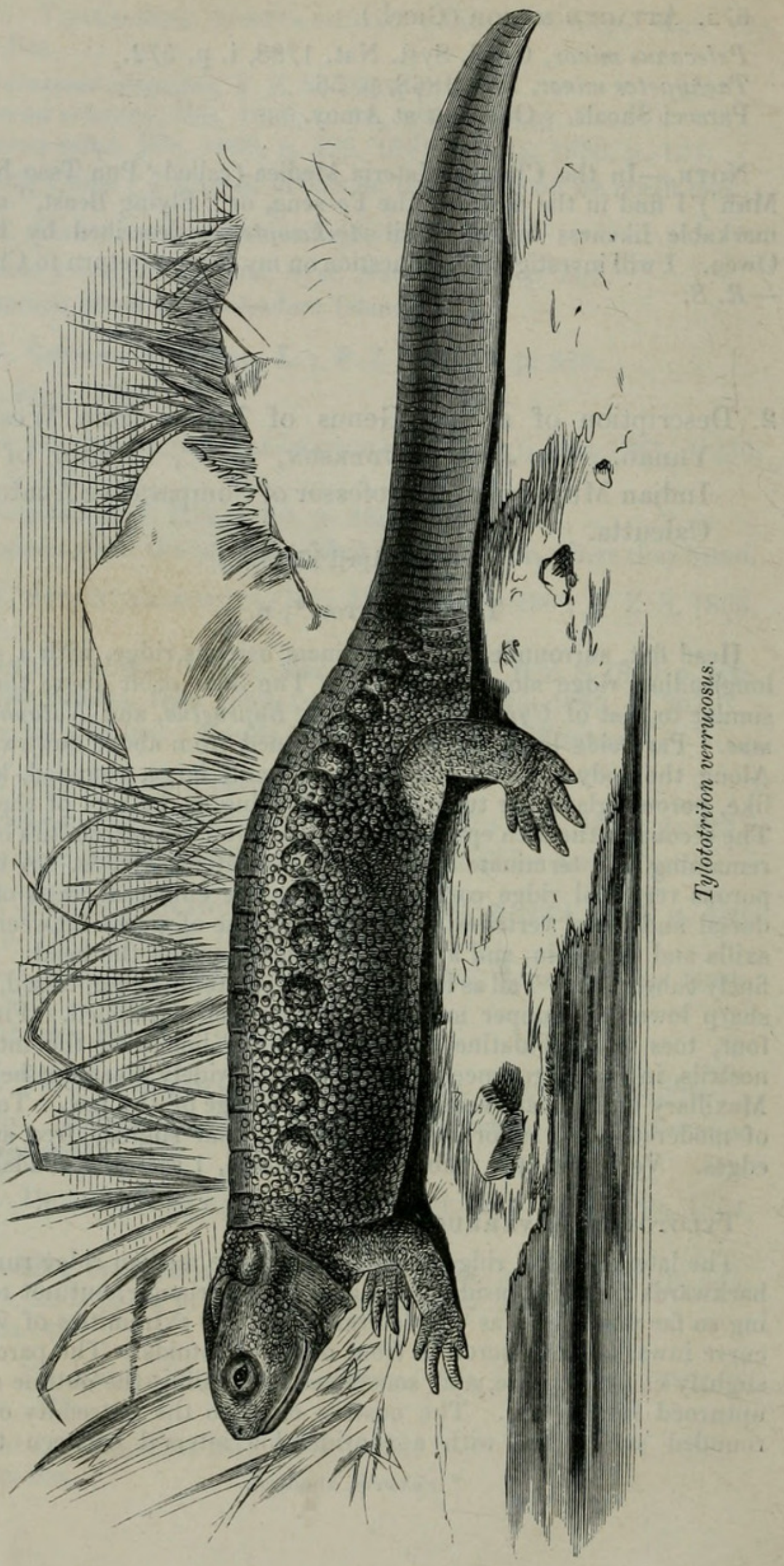


semicircular, closed by a small valvular flap of skin. Eye of moderate size; upper eyelid large, granular. Fifteen knob-like glands along the side of the body : the first a short distance behind and about the axilla and on a level with the parotoids; the last three behind the leg when it is extended at right angles to the body. The vertebral glandular ridge begins on a line with the scroll-like extremities of the cranial crest, and terminates at the root of the tail. An obscure line of pores, larger than those of the rest of the body, from below the arm to the groin, rather towards the under surface of the side. A series of pores behind the angle of the mouth along the lateral cranial ridge to the top of the snout, on the loreal region behind the eye, and along the mandible and internal to it. The chin and throat thickly covered with small, smooth, porous, glandular tubercles of nearly uniform size. The sides and upper parts of the body and of the tail are densely covered with glandular tubercles (porous) of various sizes and irregularly distributed. The ventral surface transversely wrinkled and covered with very minute porous glands, which scarcely project above the level of the skin. The upper margin of the tail sharp, and commencing with the last lateral knob. Under surface rather rounded. Numerous folds on the inner margin of the vent. Forearms extend the length of the fingers beyond the snout; the legs reach halfway to the axilla.

Uniform blackish brown, paler on the lips, snout, chin, throat, and under surface of the limbs, all of which are of a brownish-olive tinge. Under surface of the tail dull orange-yellow, fading to lightish brown on the sides.

Length from tip of snout to vent 3 to 4 inches; vent to tip of tail 3 to $3 \frac{9}{12}$ inches.

Hab. Nantin, Momien, and Hotha valleys, Western Yunan, China.

I first met with this remarkable Newt in the flooded rice-fields about the little Chinese town of Nantin, where, however, it was not very common. In the more elevated and subtemperate valley of Momien, at about a height of nearly 5000 feet above the sea, and in the high sequestered valley of Hotha ( 5000 feet) it was far from uncommon.

3. Note on Testudo phayrei, Blyth. By John Anderson, M.D.

[Received April 27, 1871.]

With reference to the correspondence between Drs. Gray and Sclater, which appeared in the 'Athenæum' of November and December last*, on the statements of Mr. Theobald regarding Dr. Gray's Scapia falconeri and Blyth's Testudo phayrei, I am in a position to

* See 'Athenæum,' Nov. 12th, 1870, Nov. 26th, 1870, Dec. 3rd, 1870, and Dec. 10th, 1870. 
state, after a careful examination of the type of $\boldsymbol{T}$. phayrei in this museum, that it is a true Testudo. I enclose two drawings, one of the sternum (fig. 1) and another of the carapax (fig. 2) of the typical specimen, and a sketch of the sternum of the imperfect specimen

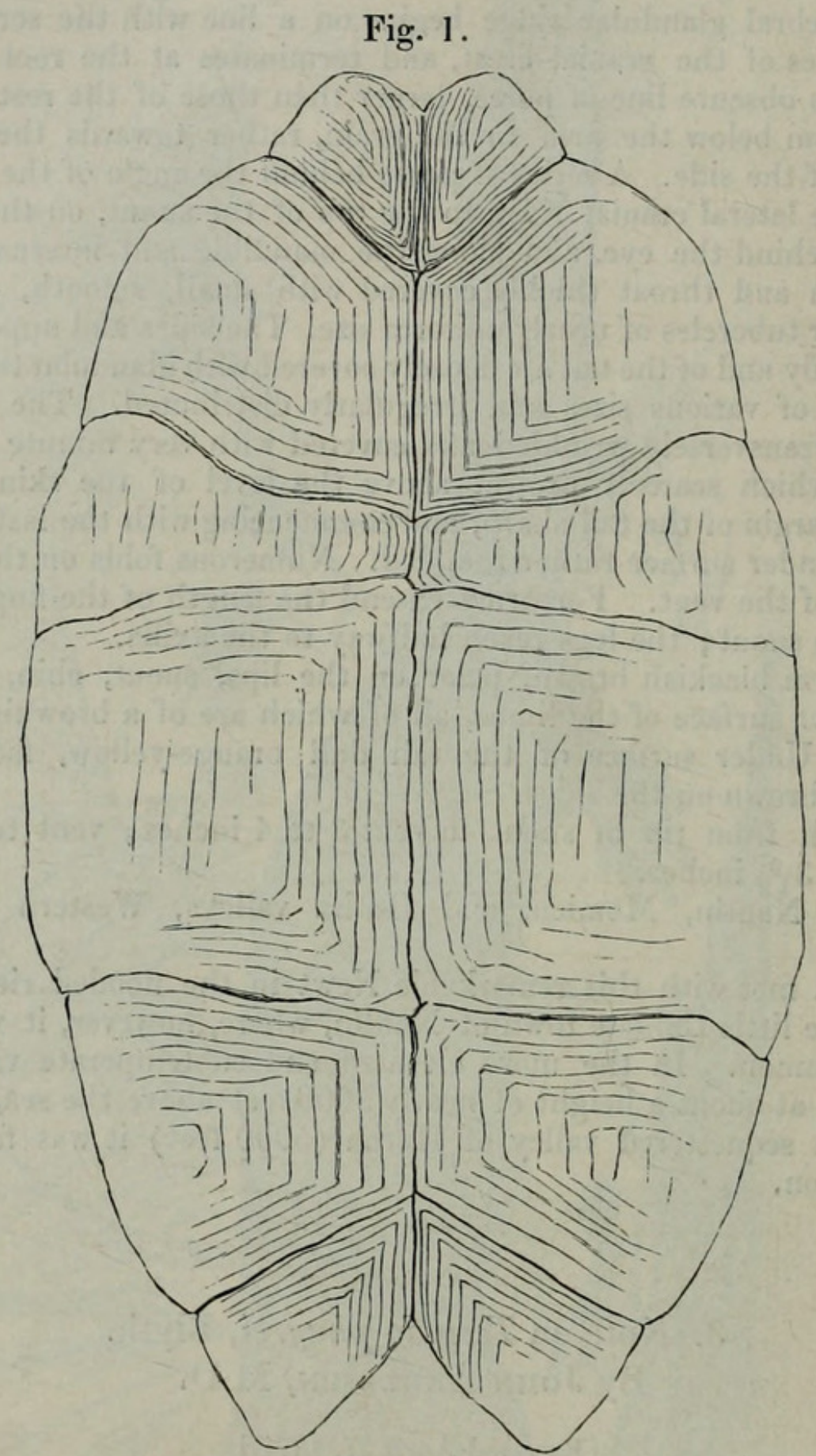

Sternum of Testudo phayrei.

on which Mr. Theobald grounded his remarks; and these drawings will prove that $I$ am correct in referring the species to the genus Testudo.

With regard to Blyth's type of $T$. phayrei, I may mention that it is still in this museum, in a perfect state, and that it was referred 
Fig. 2.

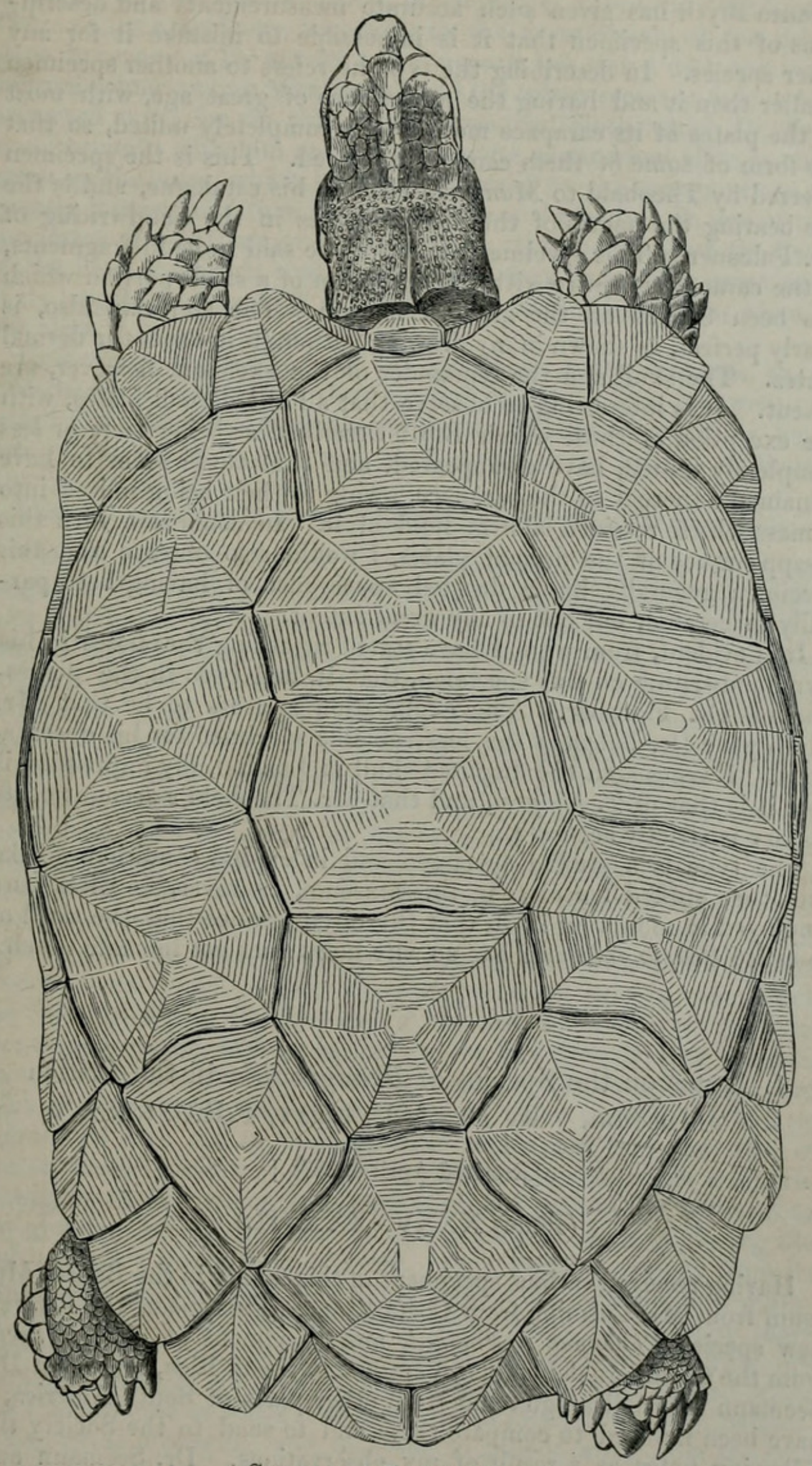

Carapace of Testudo phayrei. 
by Theobald to T.indica. I am enabled to make this identification because Blyth has given such accurate measurements and descriptions of this specimen that it is impossible to mistake it for any other species. In describing the type he refers to another specimen smaller than it and haring the appearance of great age, with most of the plates of its carapace more or less completely united, so that the form of some of them cannot be traced. This is the specimen referred by Theobald to Manouria emys in his catalogue, and is the one bearing the names of the sternal plates in the handwriting of Dr. Falconer. This specimen can hardly be said to be in fragments, as the carapace is entire with the exception of a small portion which has been broken off the anterior margin. The sternum, also, is nearly perfect, as shown in my drawing, although it wants the dermal plates. The skull and the remainder of the skeleton, however, are absent. It is interesting to observe that all the dermal plates, with the exception of those which Blyth described as being more or less completely united, have disappeared, and that these seem to have remained adherent to the carapace, owing to their being united into a mass which retained a firm hold of it. In connexion with this disappearance of the dermal plates, I would also observe that this specimen generally has a decided appearance of having been partially macerated, but not to any great extent.

It is evident, from what $I$ have stated regarding the notes in his own handwriting on this specimen, that it had been in the possession of Dr. Falconer. The explanation appears to be that $\mathrm{Mr}$. Blyth gave Dr. Falconer the less valuable specimen for his observations. Having seen the disputed skull in London, my impression is that it is that of $\boldsymbol{T}$. phayrei, and that Mr. Theobald's account of its history is strictly accurate.

The type is a stuffed specimen and in capital condition. Like the other stuffed Tortoises in this museum, however, no wires were employed in mounting it, so that the circumstance that the skull of so-called Scapia falconeri has no wire-holes does not indicate much.

\section{Notes on the Species of Bradypodide in the British}

Museum. By Dr. J. E. Gray, F.R.S. \&c.

[Received April 6, 1871.]

$$
\text { (Plates XXXV.-XXXVII.) }
$$

Having received various specimens of this family in the British $\mathrm{Mu}$ seum from Mr. Carmiol, from Costa Rica, as the type of Dr. Peters's new species Cholopus hoffmanni, and specimens of Arctopithecus from the Cordillera del Chucu, Veragua, in Costa Rica, and from Dr. Seemann from Nicaragua and from other parts of South America, I have been induced to compare them and to send to the Society the following notes as a result of my observations. Dr. Seemann and 
Mr. Janson, junior, both inquired of me if I knew any green species of Sloth, for that was the colour of the living species in Nicaragua. There seems a tendency, according to the examination of the dried skins, in several of the species to be more or less tinted with this very unusual colour among Mammalia ; and the colour seems to fade in the preserved skin ; for the skin of the three-toed Sloth, which Dr. Seemann brought with him and said was quite green when alive, is only green on the sides, which have been covered by the arms and consequently less exposed than the other parts of the body. In one of the specimens of the Unan or two-toed Sloth, the long hair of the back of the head is whitish, and more or less dark green in a great part of its length, looking as if it had been all bright dark-green when it was alive.

Unfortunately a few only of the specimens in the Museum, those more lately received, have their special habitat. The rest were received from the Zoological Society or the Haslar Hospital, or have been purchased of dealers, and have only had the habitat of South America attached to them.

I have received the following interesting letter from Dr. Seemann :-

“Dear Sir,-The Sloth (Arctopithecus) I brought home was caught in the woods surrounding the Javali gold-mine in the Chontales district of Nicaragua, about 2000 feet above the sea-level, a country having nine months of rain during the year. The natives call this animal 'Camaleon,' and say that it is very rare, which may be the case, as during all my travels in the country I have never met with it before. But, on the other hand, it should be borne in mind that it has almost exactly the same greyish-green colour as Tillandsia usneoides, the so-called 'vegetable horsehair' common in the district; and if it could be shown that it frequented trees covered with that plant (a point I hope to ascertain during my next visit in June next), there would be a curious case of mimicry between this Sloth's hair and the Tillandsia, and a good reason why so few of these Sloths are seen. When the animal first came into my possession it was much greener than its preserved skin is now, which has been dried over the fire, and it remains to be seen whether the greenness is owing, at least in part, to the fact that the hair becomes covered with minute cryptogamic organisms, the damp climate and thick gloomy forests being favourable to their growth. I had no microscope with me to clear up this point; but this you will, of course, easily ascertain. I had the animal alive for about a month, feeding it on the young leaves of Cecropia peltata, an urticaceous fast-growing tree of the district; and it used to eat most during the night, when it was also most lively. One night it escaped from its prison, and next morning was found about 800 yards off, in a waterbut, whither it had to make its way over a cleared hill, where there were no shrubs nor trees, which rather puzzled me. During my temporary absence from Javali the servants neglected to feed it, or else I had hoped to bring it to London, to present it to Dr. Sclater. It had great strength; and in order to pull it away from the tree to which it was holding, your hands were necessary. On those 
occasions it used to utter a shrill sound, like a Monkey; but I have never, on any other occasion, heard it uttering this sound.

"Hoping that some of these notes may be of service to you,

"I remain, \&c.,

"Berthold Seemann.

" 4 Westminster Chambers, Victoria Street, "April 1, 1871."

In this paper I have adopted the three genera proposed by me in the paper on the Skulls of the Family in the Proc. Zool. Soc. 1849 , and the nomenclature used in the 'Catalogue of Carnivorous, Pachydermatous, and Edentate Mammalia in the British Museum,' 1869 , p. 362.

\section{Tribe I. Cholgepina,}

The hands with two claws, the feet three-clawed. Skull large, ventricose ; front edge of the lower jaw much produced, into a spoonlike central lobe. Intermaxillary bones well developed, forming an arched edge to the front of the upper jaw. The front grinders in each jaw elongate, acute, working against each other like the canines of a Boar, the upper one being over the front of the lower one, and separated from the other grinders by a considerable vacant space. The angle of the lower jaw is thick, rounded, and only slightly produced, scarcely exceeding the back edge of the condyle; the front upper grinder placed quite close to the front end of the bone, and at a distance from the other teeth, which is the largest tooth. It is well developed and of a triangular shape in the skulls of very young animals, and separated from the other grinders by a considerable space in both jaws. It becomes much developed by age; and a large cavity is formed behind the tooth in the upper jaw for the reception of the one in the lower jaw. The malar bone short, triangular, and dilated at the end, with a short, narrow, horizontal upper process, and a broad or descending one.

In the young skull the nasal bone is small, elongate, triangular, projecting in front of the suture of the frontals. This bone is well figured in Rapp's 'Edentata,' t. iii. f. 2, 3, and is to be seen more or less distinctly anchylosed in some of the adult skulls; and the anterior process on the lower jaw is narrow. The intermaxillaries are separated from the maxillæ and from each other by narrow sutures, which are obliterated in the adults. The malar bone is elongate, produced horizontally, with a short upper rounded process and a much larger acute angular process, which is obliquely produced posteriorly. The skulls of the young specimens showing the sutures are as short and broad as in the more adult ones, except in one case (736c), where it is not above two-thirds the width; but only the front part of the jaws exist of this specimen, while there are two or three of different ages showing the sutures.

A very young skull, with a broad nose showing all the sutures, and having the nasal bone well produced, is figured by Rapp in his 'Edentata,' t. iii. f. 2, 3, as Bradypus didactylus.

The temporal muscles occupy a very different space in the series 
of skulls. In five of them ( $736 b$, young, $736 a, 607,910$, and $736 d)$ they are separated from each other by a space of considerable width. This space is much narrower behind in $1510 e$, which is a much older skull than any of the others. In three skulls $(1510 a, 1510)$ from Costa Rica, both of which are young, the temporal muscles are only separated by a very narrow ridge for about half or three-quarters of an inch; in an adult skull, that wants its hinder part (1510), they appear to approximate much further forward, but the occipital part of the skull is deficient.

The malar bones are very different in shape in the different specimens : in some the descending bone is very broad and fan-like, and in others it is comparatively small; the ascending one varies much in length, but is generally short, not reaching the zygomatic process and squamosal; but in one specimen from Costa Rica it nearly reaches the process, to which it is united by a cartilage.

There is a great difference in size, shape, and vesicularity of the pterygoids, and also in the substance, some being very thin and others thick and hard.

\section{Cholepus.}

1. Cholepus didactylus, Gray, P. Z. S. 1849, p. 65 ; Catalogue, p. 363 ; Wagn. Suppl. vol. iv. p. 158.

One, which is generally dark, has the end of the hairs of the occipital crest white, and more or less tinted with bright green.

A young specimen received from Mr. Salvin is covered with short woolly hair, of a dark brown colour, rather paler on the rump, much paler on the head, the cheeks and chin, the band across the nose, and the orbits being dark brown.

All these specimens have pale, whitish claws, while the claws of the other species are of a dark brown or blackish colour.

Dr. Peters says the $\boldsymbol{C}$. didactylus has long and $\boldsymbol{C}$. hoffmanni short claws, but I cannot see any difference in the length of the claws in the Museum specimens of the two species. The claws are short in the young specimens, and become longer as they increase in age.

There is an adult specimen in the British Museum, presented by Captain Kellett, of H.M.S. 'Herald,' without any special habitat, which agrees with Mr. Salvin's specimens in having very long hair and white claws, but is of a nearly uniform dark brown colour, rather paler on the head, and redder beneath. The hair of the middle of the back and of the cervical crest has more or less long white tips; and these tips of the hairs of the cervical crest have a decided green tint.

The specimens of this genus appear to be very variable in colour and in length of hair.

A specimen said to have come from Juan de Fuca, received from the Haslar Hospital, has short hair of nearly uniform length, and is of a uniform dark brown colour, with scarcely any indication of an occipital crest.

Two specimens from Brazil are like the former; but the hairs are longer, and the colour is rather paler, and there is a more decided nuchal crest. 
Fig. 1 .

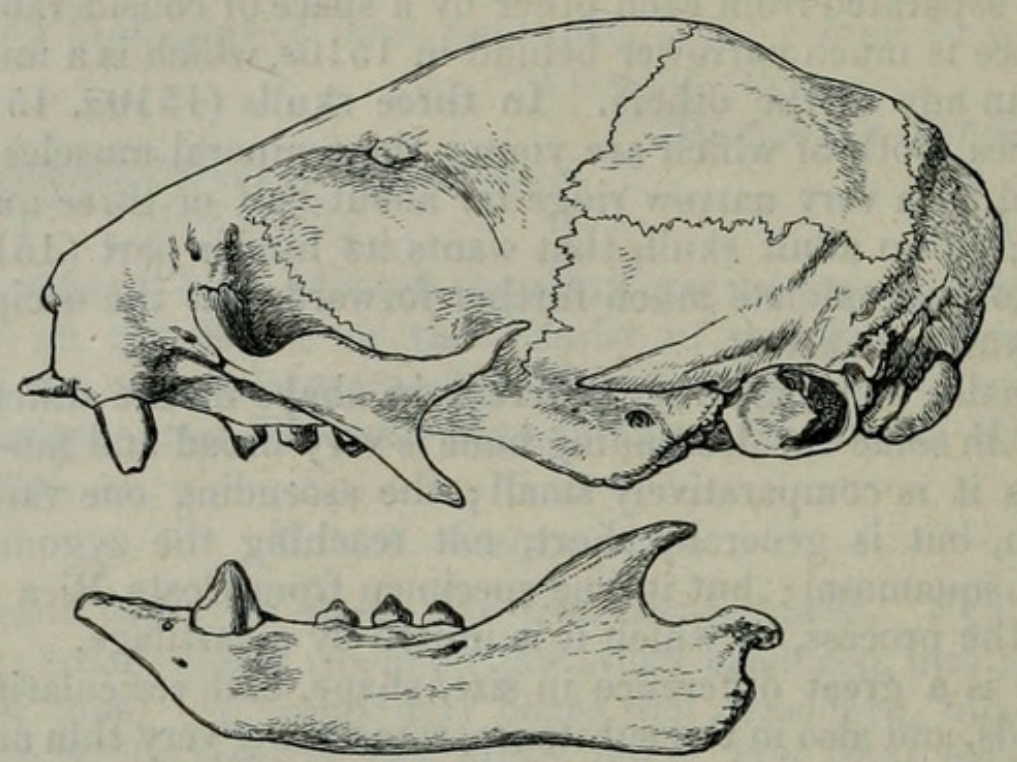

Skull of Choloepus didactylus.

Fig. 2.

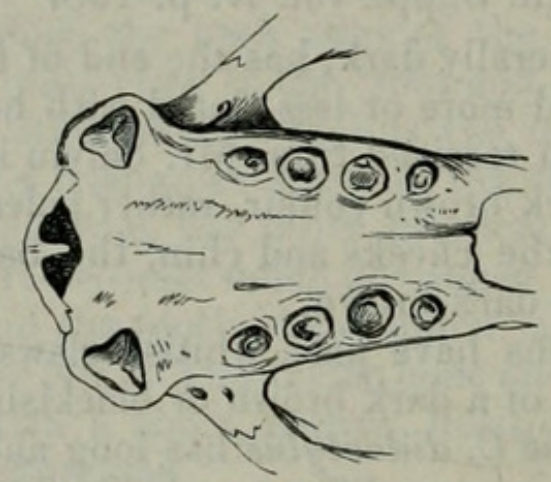

Palate of Cholopus didactylus.

Var. columbianus.

A specimen in the Museum, purchased of M. Parzudaki as coming from Columbia, is of a pale whitey-brown paper colour, darker at the root of the hairs, and has pale horn-coloured claws. I believe it is a pale variety of $\boldsymbol{C}$. didactylus, differing in being of a pale colour and having longer hairs; but, like the hairs of that species, they lay regularly and form a uniform fur, whereas the hairs in $C$. hoffmanni are irregularly disposed and scattered in all directions, forming a very rough flaccid long fur. It may be designated, until we have the power of examining more specimens and comparing its bones with other species, C. didactylus, var. columbianus.

2. Chole pus hoffmanni, Peters; Gray, Cat. of Edentates Brit. Mus. p. 363 .

A specimen sent by Dr. Peters as a type of this species, and another specimen purchased of Mr. Carmiol, from Costa Rica, as a 
typical specimen, have very long hair of a nearly uniform pale brown colour, more or less white at the tips; and they have a rery long full nuchal crest and a white face, showing distinctly a brown band across the nose extending to a ring round each eye.

The limbs of these specimens are of a darker brown colour.

There is in the Museum a series of skins apparently belonging to this animal, which were obtained by Mr. Salvin in Costa Rica. They are all peculiar for the length and abundance of their hair ; in one the upper part of the body is dark with short white tips to the hair.

Dr. Peters, when he described Cholopus hoffmanni, discovered that it had only six cervical vertebræ, the skeletons of $C$. didactylus seven; thus he proved that what had been considered an abnormal form by some, and a mistake in the describer or preparer of the specimen by others, was in reality a normal condition of two distinct species, which had been erroneously considered to be the same.

We have several skulls (namely the front part of a skull of a very young animal, and four skulls of adult animals) in the British Museum, belonging to this genus.

The width of the nose in the young skulls is exceedingly different, in the imperfect one the nose being only two-thirds; and the front process of the lower jaw is much narrower in the imperfect skull than in the other. They probably belong to two species,the imperfect one being probably $\boldsymbol{C}$. didactylus, and the more perfect one $C$. hoffmanni, as I observed that the process of the lower jaw of $C$. hoffmanni is broader than in the one said to be from the typical specimen of $C$. hoffmanni; but I do not observe the same difference in the width of the nose. The perfect young skull $(736 b)$ is very convex above.

The adult skulls are of two very different forms.

Two of them are very broad, slightly convex, crown flattened behind towards the occiput and expanded over the hinder orbital prominence, which is broadly produced. They are considerably wider in this part than the skulls of the other form. The process of the lower jaw slightly tapers on the side to a rather pointed end. The two others are very convex and gradually arched above, narrowed and shelving towards the occiput, and regularly shelving down over the hinder orbital process, which is acute. The prominence of the lower jaw is broad with nearly parallel sides and rounded at the end.

The noses of the two varieties are nearly of the same width; but the one with the flattened crown has the nose more flattened above, and the other is more evenly convex and shelving on the sides.

I cannot decide if these characters are those of two distinct species, or characters of the two sexes. I should have decided in favour of the former hypothesis; but the two skulls which we have extracted from the skins which were sent to us as the skins of $C$. hoffmanni present both varieties.

The hinder openings of the nostrils and the groove between the pterygoids are in the one with the flattened crown very different from those in the other specimen: the groove is wider in front

Proc. Zool. Soc.-1871, No. XXVIII. 
near the internal nostrils, in the other the groove is narrow and the opening of the internal nostrils much more constricted; but one of the skulls with the arched forehead $(1510 e)$, received from Capt. Kellett, has the grooves of the pterygoids much wider than in the others, and rather contracted instead of dilated in front at the opening of the nostrils.

a. Crown flattened, broad. Bradypus didactylus, Blainville's Osteog. t. iii. fig. (skull, adult and young).

Skull $(736 a)$, adult. Columbia.

Skull (736b), young. B. didactylus, Rapp, Edentata, t. iii. fig. 2,3 .

Skull with the nose very deformed. Cholopus hoffmanni. Veragua.

$b$. Crown arched longitudinally and transversely.

Skull adult $(736 d)$. Ecuador.

Skull adult $(1510 e)$. Cholopus hoffmanni, Capt. Kellett, is peculiar for having the nasal bone prominent beyond the edge of the nose and thoroughly anchylosed to the other bones.

$c$. Skull very young. Nose only preserved, narrower than the rest. No. $736 c$.

The skull from the very adult skeleton (1510b) appears to belong to this variety; but the flatness of the hinder part of the crown renders it intermediate between the two. It has a very broad canal between the pterygoids, like the skeleton $(1510 e)$; and the pterygoids of these two skulls are not nearly so vesicular as in the other specimens.

$d$. There are three skulls of young animals, one received from Dr. Peters from Costa Rica as Choloepus hoffmanni, and two received from Costa Rica by Mr. Salvin.

They are all peculiar for having the scars of the temporal occupying the whole of the hinder part of the skull, and only separated from each other by a narrow ridge. The oldest of the three $(1510 \mathrm{e})$ has a rounded convex forehead and a narrow groove between the pterygoids, which are dilated in front, and a small distinct nasal. The next in age $(1510 a)$, received from Dr. Peters, has a broad more flattened forehead; and the smaller one, from Mr. Salvin $(1510 d)$, has a still more flattened forehead; these two have a very broad groove between the pterygoids, narrowed in front; in fact the skulls of the species of Choloepus are exceedingly variable in external characters in specimens from the same locality.

\section{Tribe II. BRADYPodina.}

Hands and feet three-clawed. Skull oblong. Front end of the lower jaw truncated, without any or only a very short anterior spoonlike lobe. Intermaxillaries rhombic, rudimentary, not united to the front of the maxilla, generally lost in maceration. The front upper grinders small, cylindrical, truncated, not nearly so large as the others. The second upper grinder largest, generally gradually smaller backwards. The front lower grinder broad, compressed, 
broader than the rest. The others cylindrical, the hinder the largest. The front upper grinder in the very young specimen is small and conical when the other grinders in the upper and lower jaws are well developed, being very different in this respect from the twotoed Sloths or Choloepi. The malar bone moderately short, with a large inferior process and an elongated ascending superior process, which is often more or less dilated at the end, especially in the genus Bradypus.

\section{Bradypus.}

\section{Bradypus, Gray, P.Z.S. 1849, p. 67.}

Pterygoid swollen, hollow, vesicular. Males and females similar. Lower jaw with a short truncated anterior lobe varying in width at the anterior end. Intermaxillary bone rhombic, as broad as long. The angle of the lower jaw is broad, triangular, with a rounded lower edge, and produced far behind the condyle (see skulls, P.Z.S. 1849 , p. 65 , t. x.). The lower ramus of the malar bone is simple, elongate, triangular, and the upper ramus much produced and dilated at the end.

De Blainville figures a skull of a young animal under the name of B. torquatus, t. iii.; but the figure looks much more like the skull of an Arctopithecus; for it does not represent the peculiar dilated appearance of the upper malar bone.

The three nearly adult skulls of Bradypus in the British Museum vary in the flatness or convexity of the front of the forehead, two of them being rather narrow and concave between the orbits, and one (see Bradypus crinitus, P. Z. S. 1849, t. x. f. 1) convex and wider. I have figured the latter under the name of B. affinis in the 'Proceedings' of this Society, 1849, t. x. f. 2 , skull $(737 a)$.

This skull $(737 a)$ which I have so distinguished differs in several other points from the other two; that is to say, it has a rather narrower hinder opening to the nostrils, and the vesicular pterygoids, instead of being broad and ovate, are narrow, as in $923 a$ and $b$, elongate, and compressed; and I am inclined to think these indications of a distinct species, but they may be marks of the sex. The nose is rather narrower.

\section{Bradypus crinitus.}

Skull rather concave between the eyes.

Bradypus torquatus, Prince Maximilian, Abbildungen, t. (good figure of female).

Bradypus crinitus, Gray, P.Z.S. 1847 , p. 67 , t. x. f. 1 (skull); and Cat. Edentata B. M. p. 364.

Hab. Brazil, Para, Rio Janeiro.

We have three specimens of this species in the British Museumone from Brazil presented by Lord Stuart de Rothsay, the others without any precise locality, but said to be from South America. They are very much alike, but vary in the length of the black nuchal crest and in the intensity of its colour ; in the largest specimen it is the shortest and of a brownish black colour; none of the specimens 
has the brown tint of the figure of Bradypus torquatus, Illiger, represented in Wagner's 'Supplement to Schreber's Säugthiere,' tab. lxiv. A.

\section{Bradypus affinis.}

Skull rather convex between the orbits.

Bradypus affinis, Gray, P. Z.S. 1849, p. 68, t. x. f. 2 (skull); Cat. Edentata B. M. p. 364 .

\section{Arctopithecus.}

Pterygoids compressed, crest-like, solid. Males with a patch of soft hair between the shoulders not found in the females. Intermaxillary bone rhombic, with an attenuated process behind. The front of the lower jaw broad and truncated, sometimes with a slight keel in the centre near the upper margin. The front grinders are short and blunt. The upper process of the malar bone attenuated.

Arctopithecus, Gray, P. Z. S. 1849, p. 69 ; Cat. Edentata B. M. p. 364 .

The hinder angle of the lower jaw differs very considerably in shape, as I showed in the 'Proc. Zool. Soc.' 1849, t. xi. f. 1, 3, $4,5,6$. The sutures between the bones of the face are often distinguishable in well-developed skulls, which evidently belong to fullgrown animals.

In the two preceding genera no difference has been observed between the colour of the males and the females; but from numerous observations that have been made upon specimens of this genus I think that it may now be established that the males are ornamented differently from the females - that is to say, that they have a patch of soft short hair between the shoulders, which is generally of a more or less orange-colour, and in one species pure white. The females, on the contrary, are destitute of this mark. Both sexes generally have a more or less distinct black dorsal streak and abundant soft under-fur which agrees in colour with the long hair above it.

As this difference of the colouring of the sexes has produced various opinions, and sometimes caused the sexes of the same animal to be regarded as distinct species, I have given a résumé of the various ideas on the subject, and of the characters that have been given of the species by the authors who have studied the whole genus.

Buffon (Histoire Nat. xiii. 1765, p. 60), in his account of the Aï, figures what he calls the "jeunes Aïs" (tab. v.), which are probably young females, and "l'Aï adulte" (tab. vi.), which is evidently a male. Daubenton in his description calls this the first specimen, and observes that he gives to it the name of "Aï de dos brûlé, parce qu'il semble que son poil ait été en effet brûlé sur la dos."' This is evidently the male of $A$. blainvillei; for he says the head and neck are covered with long flexible brown-black hair; and the young (the second), he says, chiefly differs from the former by the face being surrounded by yellowish and the head and neck blackish; therefore it is difficult to say whether it is the female of Bradypus 
blainvillei or cuculliger; but it is most probably the former, as he says that the throat is brown.

Cuvier, in the 'Animal Kingdom,' edit. 1, vol. i. p. 217, says, "Sa couleur est grise, souvent tachetée sur le dos de brun et de blanc; plusieurs individus portent entre les épaules une tache d'un fauve vif que traverse une ligne longitudinale noire. On ignore s'ils forment espèce." He adds, "On connaît un Aï dit le dos brúlé, parce qu'il a entre les épaules une tache noire entourée de fauve; ce n'est selon M. Temminck, qu'une variété résultant de ce que des longs poils de ses épaules sont usés.” (Cuvier, Règ. Animal, ed. 2. p. 225.)

Dr. John Wagler, in the 'Isis' for 1831, p. 604, wrote an essay on the genus Bradypus, of which he notices four species:-1. B. cuculliger, from Surinam, Cayenne, and Guiana ; 2. B. ai, from Brazil ; 3. B. torquatus, Brazil ; 4. B. infuscatus. He considers the female of $\boldsymbol{B}$. cuculliger and $\boldsymbol{B}$. infuscatus distinguished by an orange or yellow spot on the middle of the back between the shoulders; for he says particularly in the description of B. cuculliger, "Macula spinæ dorsi (in fœemina) pone humerum subrotunda, læte aurantiaca, medio longitudinaliter vitta aterrima dissecta" (p. 605), and that, in $B . a i$, "Macula spinæ dorsi (in fœmina) pone humerum subrotunda, pilis adjacentibus plus minusve tecta, fuscescenti-flavida, vitta per medium nigrescente longitudinaliter signata; pili hujus maculæ mollissimi sunt, quasi sericei ;" and he describes a new species under the name of $\boldsymbol{B}$. infuscatus with the following character:- "Intense fuliginoso-fuscus, seriebus macularum in dorso fuscescenti-albarum longitudinalibus quatuor; fronte temporibusque flavido-albis; vitta utrinque pone oculum oblique ad mentum deducta distinctissima fusco-atra inferius flavido-albo limbata; collo toto anteriore ac gastræo notæi colore, immaculatis. Adult.

"Pili appressiores quam in speciebus præcedentibus, multo breviores, ungues ac extremitates longiores, multo graciliores; hi fuscescenti-flavi; pedes supra albido maculati.

"Longitudo $1^{\prime} 11^{\prime \prime}$, caudæ $1^{\prime \prime} 11^{\prime \prime}$, antibrachii, exclusis unguibus $15^{\prime \prime}$, scelidum $8^{\prime \prime} 2^{\prime \prime \prime}$.

"Habitat in Brasilia versus Peru."

Dr. John Andreas Wagner, in the Supplement to Schreber's 'Säugthiere,' iv. 1844, p. 132, describes four species of Bradypus (including B.torquatus); but he evidently regards the orange mark on the back as the character of the male, and not of the female as Wagler had considered them.

1. B. pallidus, Wagner, he says, is B. tridactylus of Cuvier, and $B$. ai of Wagler; and at p. 143 he gives to it the following characters:-

" $B$. e rufescente pallide cano-lutescens; notæo longitudinaliter albomaculato; fronte alba; vitta utrinque post oculum oblique ducta fusca ; collo gastræoque notæi colore, immaculatis ; macula dorsali aurantio-fulva nulla." This cannot be the Bradypus ai of Wagler, which he thus describes:-_" Cinereo-fuscescens sive rufescens, notæo tæniis duabus longitudinalibus albido-maculosis notato ; fronte alba ; vitta utrinque pone oculum oblique retrorsum ducta obscure fusca, 
inferius albido limbata ; collo anteriore toto ac gastræo notæi colore, immaculatis. Adult.

"Animal junius. Rufescens; notæo distinctius albo-bivittato; fronte stricte aut vix alba; vitta oculorum breviore, ad initium supra et subtus rufescenti-albo limbata.

"Macula spinæ dorsi (in fomina) pone humerum subrotunda; pilis adjacentibus plus minusve tecta fuscescenti-flavida, vitta per medium nigrescente longitudinaliter signata ; pili hujus maculæ mollissimi sunt, quasi sericei; pedes supra albido maculati; ungues albo-flavidi." (Isis, p. 610.)

I have seen no specimen that agrees with Wagner's description.

2. B. cuculliger, Wagl. Isis, 1831 , p. 605 .

$B$. cano-brunescens, irregulariter albo maculatus; sincipite facie guttureque pilis abbreviatis flavido-albis vestitis ; occipite cerviceque pilis longioribus umbrino-fuscis supra juguli latera decumbentibus, stria postoculari nulla; vitta dorsali fusca, maculam ơ aurantiacam persecante."

This, he says, is gularis of Rüppell, the Aï (adulte) of Buffon (tab. v. \& vi.), and the "Ä̈ à dos brûlé" of Daubenton. I think that this latter reference is a mistake, as Daubenton describes the throat as brown.

Wagler describes properly the streak before and behind the eye as very short, which agrees with our specimens; but Wagner says there are none, which would seem to indicate that his species must be different.

3. B. infuscatus, Wagl. Isis, 1831 , p. 611 .

" $B$. fuliginoso-fuscus, supra seriebus longitudinalibus macularum albidarum subquaternis; fronte temporibusque flavido-albis; vitta utrinque post oculum oblique deducta nigra ; vitta dorsali fusca, maculam of aurantiacam persecante.

"Var. a. Intense fuliginoso-fusca, maculis dorsalibus dilute brunnescentibus; mandibula gulaque fuscescentibus.

"Var. $\beta$. Maculis dorsalibus sordide albidis, mandibula gulaque pilis bicoloribus apice longius flavescentibus, basi fuscis.

"Var. $\gamma$. Paululum pallidior, mandibula gulaque brunnescentibus aut sordide lutescentibus." (Wagner, Supp. to Schreber's Säugt. iv. p. 148, 1844.)

The character here given is a mere transcript of the one given by Wagler as quoted in a former page; but he adds that the male has an orange dorsal spot, which is not mentioned by Wagler.

Mr. Bridges considered the specimen he brought from Bolivia, with a yellow patch on the back, to be the male of the specimen without it; but we had no verification of the fact.

In 1845, Rüppell, in the 'Mus. Senckenbergianum,' iii. p. 138, described a Sloth with an orange patch on the back as a species under the name Bradypus gularis, and at tab. xi. gires two figures of it, one of them being coloured.

In my monograph, published in the 'Proceedings of the Zoological Society' for 1849 , p. 69 , under these conflicting opinions I cousidered the orange mark a specific character, and adopted Rïppell's 
Bradypus gularis for what are now considered the males of more than one species.

Mr. Salvin, in June 1869, informed me that the series of four specimens of $\boldsymbol{A}$. griseus, which he obtained for the British Museum, were all shot together, and formed one family, consisting of a male, a female, and two young of different ages; that the male had a yellow patch with a black central streak on the back, which was not present in the female and young. This observation induced me to examine the other specimens in the Museum which have the yellow patch on their backs; and I am satisfied that they belong to two species, which agree in all the characters, except the patch, with the two species that I had named Arctopithecus marmoratus and Arctopithecus blainvillei; and therefore I have come to the conclusion that they are the males of those species. One cannot be certain, because the sex of the specimens cannot be determined in the skins as they are in the Museum, and the travelling naturalists who collected them have not taken the trouble to mark the sex to which they belonged. I think this idea is confirmed, that all the young specimens which I have seen are like what are here regarded as females, and perhaps the patch does not appear until the animal reaches nearly adult age. The under-fur is generally abundant, very soft. It is white or black, like the base of the longer hair. It seems to be more abundant in the species with long flaccid hair, which generally have grey tips to the hair, and shortest and least abundant in $A$. cuculliger, which has shorter and more rigid hair, and is rather sooty-coloured.

Cuvier, in the 'Ossemens Fossiles,' v. t. 6, 7, figured the skeleton and skull of this genus, $A$. problematicus?

Blainville, in his 'Ostéographie,' figures the skulls of two animals ; one he calls B. tridactylus brasiliensis, and the other B. tridactylus guianensis, differing in the hinder part of the lower jaw.

In my paper in the 'Proceedings' 1849, I pointed out that the hinder part of the lower jaw seemed to afford very good characters for the separation of the species, and figured this part from several specimens.

The species may be arranged according to the skull thus (and I have found them subject to little or no variation in general form, and change little in growth) :-

1. Skull: nose rather elongate, narrow; lower jaw elongate, shallow, the hinder angle much produced. $-A$. cuculliger, $A$. marmoratus.

2. Skull : nose rather elongate, narrow; angle of lower jaw rather produced, broad. - $\boldsymbol{d}$. problematicus.

3. Skull: nose very short, broad; angle of lower jaw produced, broad.-A.boliviensis, A. Aaccidus, A.griseus, A. castaneiceps.

4. Skull : nose very short, broad; angle of the lower jaw scarcely produced, very broad. $-A$. blainvillei.

In this and my other paper of the kind I have only paid attention to the zoological characters of the skulls, and not preferred to 
examine and describe them osteologically; not that $I$ in the least underestimate the value of this very interesting and important branch of science; but the theory of the structure of the skeleton has very little to do with the zoological distribution, and, to judge by the results, a scientific man who has paid great attention to that study may have a very imperfect idea of the value of the zoological character afforded by the skull as a whole, and most crude ideas of the connexion of the genera with one another, even in examining the perfect skeletons of living animals; indeed such ideas make one lose all confidence when the same kind of study is applied to fossil remains. I need only refer to the extraordinary mistakes that have been made in naming the skulls of such large animals as Crocodiles, Rhinoceroses, Tapirs, and Cetacea by one of the most celebrated osteologists, in which he has given the same species various names and included under the same name several most distinct species; and if this be the case where perfect specimens are to be examined, what must we expect of multitudes of genera established on small fragments found in a fossil state, or of the affinities they are said to present. Paleontology, as it is called, will never be worthy the name of science until the paleontologist has a good knowledge of recent species and their characters, and the bones of the recent and fossil species are studied together.

I. Fur moderately long and rather rigid, dark grey; back with a dorsal streak and distinct white spots. Males with a large yellow patch of soft hair on the back.

a. Forehead, cheeks, chin, and throat with short, erect, rigid, yellow hair.

1. Arctopithecus cuculliger. The Yellow-throated Ai. B.M.

Forehead, temple, chin, and throat covered with short, erect, yellow hair, surrounded by a more or less broad black collar; spot behind the eye small; fur blackish, short, rigid; under-fur short, sparse. Skull : nose rather elongate, narrow; lower jaw moderately strong; the front lower grinder flat, smooth, and moderately broad in front; angle of the lower jaw much produced, slender, elongate.

0 and o. Bradypus cuculliger, Wagler, Isis, 1831, p. 605; and Wagner, iv. p. 145 ? Rapp, Edentata, v. t. 3. f. 1 (skull).

Braảypus tridactylus guianensis, Blainville, Ostéog. t. ii. fig.

Arctopithecus gularis (part.), Gray, Cat. Edentata, p. 364 ; P. Z. S. 1849 , t. xi. f. 6 (angle of lower jaw).

q. Blackish; shoulders, back, and haunches covered over with close large black spots. The head and throat yellow.

Young. Fur long, soft, and flaccid, grey-brown ; back whitish, mottled; face and throat yellowish; eye-streak and circumference of head and neck blackish.

Hab. Guiana (Rüppell); Demerara, Brit. Mus.

Wagner says this species has no postocular streak; but this does not agree with our specimen. The fur of the female in the Museum 
is not so harsh as that of the males, and is blackish grey closely white-spotted; but the colour of the face and throat are the same.

A young specimen in the Museum, obtained from Mr. Warwick, has the fur very soft and greyer than in the adult, and therefore the white spots are less distinct; the black postocular spot is small but distinct. It is curious that Dr. J. A. Wagner, in his specific characters of B. cuculliger, particularly marks "stria postoculari nulla." In our specimens it is distinct, but smaller than in B. infuscatus.

Variety. Male : the dorsal patch dark orange-yellow with a broad tapering black central streak and a black spot, but with the outer margin of the same colour as the rest of the back, and not intense black as in the other specimen.

\section{$\mathrm{Hab}$. - ? B.M.}

\section{Arctopithecus gularis.}

Fur much longer and more flaccid, brownish grey, with large blotches of white on the back.

o. Bradypus gularis, Rüppell, Mus. Senck. 1. 2. 3, p. 138, t.

Hab. Surinam (C. Bartlett).

We have only a skin, without the skull, of a half-grown animal; the length of the fur does not appear to depend upon age, as it is longer than in the female of the more rigid-haired species in the Museum. It may prove to be a distinct species when the skull is observed.

Wagner describes $B$. cuculliger as having coarse, brittle, long whitish-brown hair ; and he quotes B. gularis, Rüppell, as a synonym of it. Rüppell describes his species as "corpore pilis longis laxis ;" and further, the hair of three kinds:-first, long, cylindrical, and soft to the feel, mostly of a blackish colour; second, more elongate and perceptibly compressed at the ends, and whitish; third, fine short woolly hair among the other, grey or white. Our specimen which agrees with this is without the skull; and Rüppell does not describe or figure the skull of his specimen; so we do not know if it is like, or different from, $A$. cuculliger.

b. Nose and forehead covered with short soft yellow hair, which is erect at the hinder part of the forehead; cheeks, chin, and throat covered with thin harsher hair, like the rest of the body.

L'Ai adulte, Buffon, Hist. Nat. vol. xiii. tab. vi.

L'Ai second à dos brúlé, Daubenton in Buffon's Hist. Nat. vol. xiii. p. 62 .

Acheus ustus, Lesson, Espèces des Mammifères, p. 271, from Buffon's figure, is a male of a species of this section.

The Bradypus ai and B. infuscatus of Wagler, Isis, 1831, pp. 611, 612 , and $B$. pallidus of Wagner, appear to belong to this division; but I cannot fit them on to any of the specimens in the Museum.

3. Arctopithecus blainvillei.

B.M.

Forehead and temples with short, erect, yellow hair ; chin, cheeks, 
and throat with hair like the back, but rather darker. Skull: the upper postorbital tubercle scarcely produced; the lower jaw short, strong, the front part high and much thickened; angle of the lower jaw broad, rounded, and scarcely produced. (P. Z.S. 1849, t. xi. f. 2 , no. $919 a$ ).

Bradypus tridactylus brasiliensis, Blainville, Ostéogr. Bradypus, t. ii. (skull).

Arctopithecus blainvillei, Gray, P.Z.S. 1849, p. 71, t. xi. f. 2 (skull); Cat. Edentata, p. 365.

Hab. Brazil.

There are four skulls of this species in the British Museum, which are all very much alike, but differ in the convexity of the forehead. There are two specimens with their skulls, and one younger, which appear to belong to the same set. The front lower grinder is moderately broad and flat and smooth in front in all the four specimens, not quite so broad as the corresponding tooth in A. boliviensis; and the lower jaws are rather stronger and blunter in front than in that species.

4. Arctopithecus boliviensis.

B.M.

Blackish grey ; frontal band extending on to the temples, streak under the eye-streak and cheeks white; forearms, shoulders, and front of the back mottled with whitish colour; hinder part of the back, rump, and thighs white, with one or two small brown spots; chin and throat blackish grey, like the back. $\delta$. Patch on the back

Fig. 3.

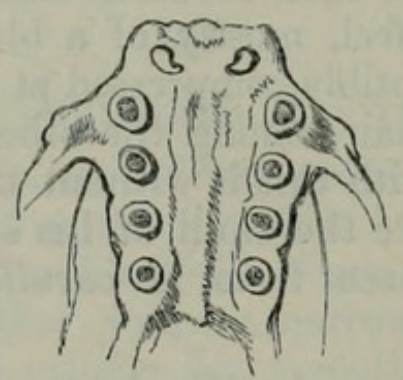

Palate of Arctopithecus boliviensis.

Fig. 4.
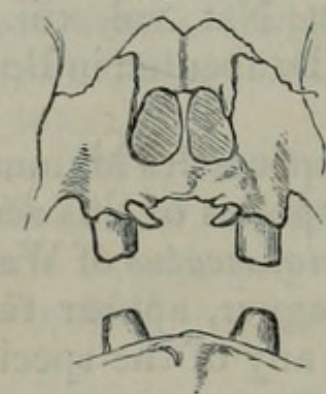

Front view of skull of Arctopithecus boliviensis. 
orange with a black stripe. The lower jaw short, thick, and strong; the angle of the lower jaw slightly produced beyond the condyle, rounded at the end $(921 a)$.

Arctopithecus gularis (part.), Gray, P. Z. S. 1849, t. xi. f. 6 (lower jaw).

Q. Back with a distinct black stripe, with white spots up to the shoulders $(920 b)$.

Arctopithecus marmoratus (jun.), Gray, P. Z.S. 1849, p. 71, t. xi. f. 4 (lower jaw).

Hab. Bolivia (Bridges).

This species is quite distinct from $A$. cuculliger. A. gularis was formerly thought to include all the species with an orange spot on the back.

The front lower grinder is large and broad, flat and smooth in front, both in the male and female specimens; and the upper front grinder is equally rounded.

There is a series of two males, a female, and young of this species in the Free Museum at Liverpool, from Bolivia, with their skulls. They are all very similar in the form of the lower jaw. The young has very flaccid hair and is probably a male, as it has a small spot of soft black hair between the shoulders, probably the commencement of the dorsal patch.

\section{Arctopithecus marmoratus.}

Fur grey-brown; back, shoulders, and rump white, black-spotted; forehead and sides of face with very short soft white hair, which only thinly covers the nose ; eye-streak brown; dorsal streak distinct. Skull : nose narrow, rather elongate; upper front grinder narrow, cylindrical. Lower jaw slender, elongate, thickened in front ; hinder angle much produced beyond the condyle, tapering, rounded at the end (P. Z. S. 1849, t. xi. f. 3). Front lower grinder rather broad, three-ribbed in front.

Male unknown.

Arctopithecus marmoratus, Gray, P. Z.S. 1849 , p. 71 , t. xi. f. 3 (lower jaw); Cat. Edentata B. M. p. 305.

$H a b$. Brazil.

The lower jaw of this species is much more slender and weaker than either of the preceding, and in this respect and in the form of the hinder angle it is like the lower jaw of A. cuculliger, but is distinguished from both sexes of that animal by having the chin and throat covered with grey-brown decumbent hair, like the back. It was this similarity that induced me to refer De Blainville's figure of the skull of $A$. cuculliger to this species in my former paper.

There is a second specimen in the Museum of which I have not seen the skull, which is somewhat like the type; but the arms and shoulders are blackish grey, not varied. This specimen is very peculiar for the fur between the shoulder being softer than usual; but there is no indication of any yellow spot. It may be a distinct species from any here described. 
These three species with a spotted back and frontal band of soft white hair are very much alike externally, though they have differences which are not easily expressed in words; but perhaps they would be more easily defined if we had a larger series of both sexes with an accurate account of the locality which each form inhabits. They are easily distinguished by the form of the lower jaw, a character that I pointed out in my former paper published in the 'Proceedings' of 1849 . That this character is permanent and not unimportant in the economy of the animal is proved by the examination of several specimens. Thus we have four skulls of $A$. blainvillei, and two of $A$, marmoratus.

The outline of the hinder part of the lower jaw of $A$. boliviensis is intermediate between those of $A$. blainvillei and $A$. marmoratus; but this must almost always occur when three jaws are compared together in a proper series for the purpose. This does not, however, form any ground for believing them to be variations of the same form or species. The difference of form appears to be constant when several skulls of the same species are observed. It is so, certainly, in five skulls of $A$. blainvillei in the British Museum. I have never seen any lower jaws that seem to me to pass by intermediate gradations from one of these forms to another. The longproduced hinder angle appears to be always in connexion with the elongate slender jaw, and the shortly produced one with the short, high, strong part of the jaw.

In fact the species of this genus are very imperfectly understood, and, I believe, will prove to be more numerous than has hitherto been believed.

This paper is the result of examination and re-examination of the large series of specimens and skulls and other bones of these animals in the British Museum, which has occupied me three or four hours a day for upwards of three weeks, not consecutively, but leaving time between the different examinations that the mind might come fresh to the subject-in the same manner as I have worked out other monographs which have lately appeared.

There is not much inducement to bestow this labour on the groups ; for no sooner does the result appear, than some tyro in zoological studies, probably more a sportsman than a zoologist, who has shot and measured a few animals, comes to the Museum, casually inspecting the specimens, sometimes overlooking the most important of them, and gives his opinion, ex cathedrâ, on what he considers the distinctions of the species or their synonyma; and unfortunately the compilers who come after the working zoologist, regard all the writers as of equal authority, and thus throw back the progress of science.

c. Nose, forehead, cheeks, and chin covered with reflexed hair, like the back, which is shorter and bent forward over the nose.

6. Arctopithecus castaneiceps. (Plate XXXV.)

Fur rather elongate and flaccid, blackish grey ; hinder part of the 


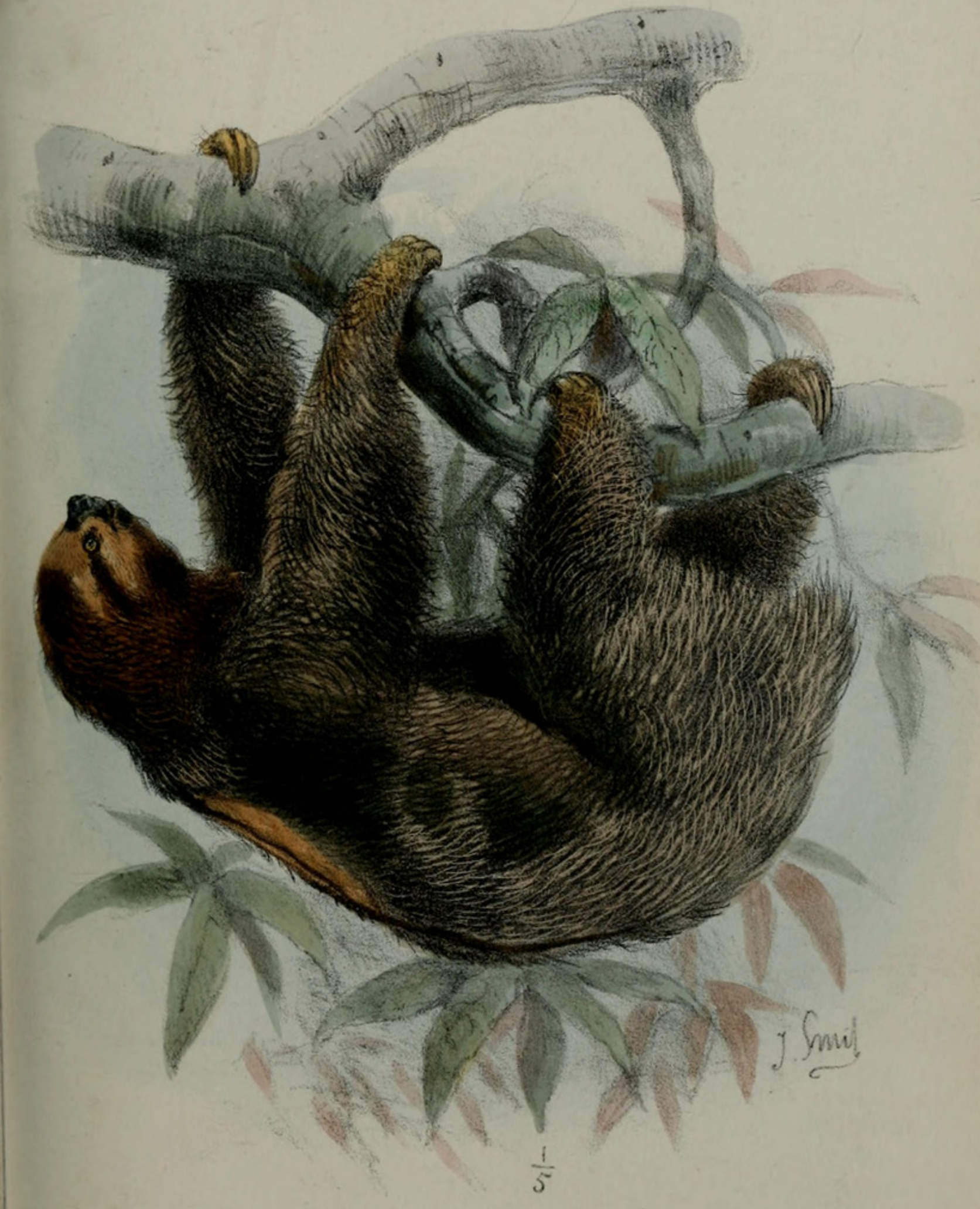

mit lith 


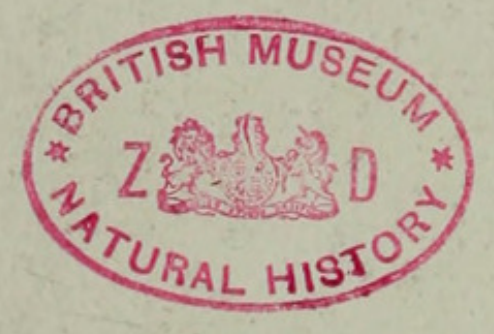


back and loins whitish, browner on the rump and hind legs; head, throat, and sides of neck covered with elongated chestnut-brown hair, forming a kind of hood on the sides; forehead paler, yellowish ; eye-streak dark brown; dorsal patch large, orange-colour. Angle of the lower jaw large, broad, rounded at the end, and much produced beyond the condyle. Female unknown.

Fig. 5 .

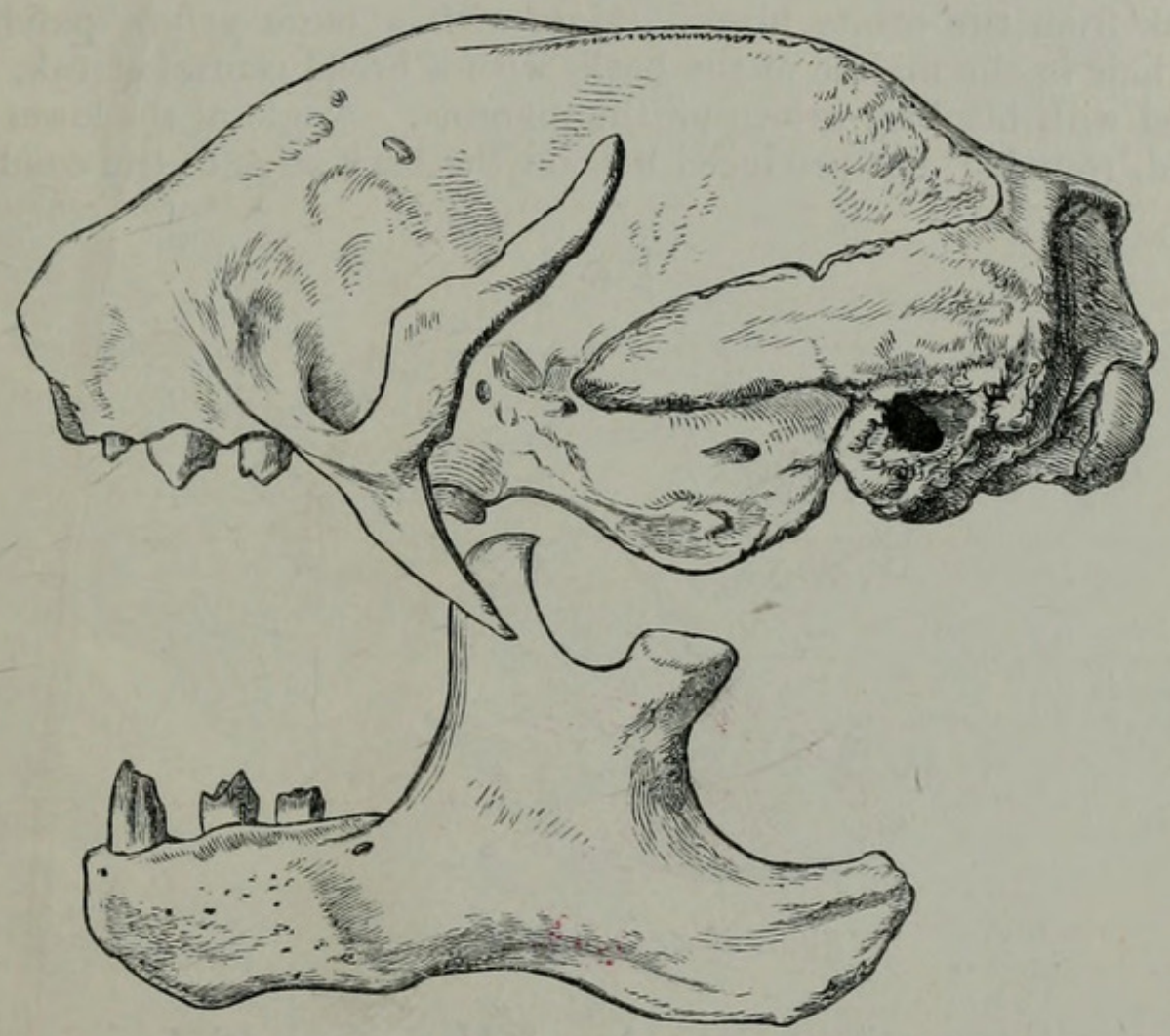

Skull of Arctopithecus castaneiceps.

Dr. Seemann brought this specimen from Nicaragua. He says it was bright green when alive, as mentioned in his letter. The specimen does not now exhibit any of the green tint in the parts exposed to the light; but the sides of the body, covered by the arms being pressed against them, retain still some remains of it.

Hab. Nicaragua (Dr. Seemann).

This cannot be Bradypus infuscatus of Wagler; it does not agree with the description. It is a male (?), with long fur of a grey-brown colour intermixed with white hairs. The face, forehead, cheeks and chin are of a reddish brown, the under part of the body is pale brownish white, the sides of the neck have a long ruff of recurved dark brown hair, darker than that of the face. The shoulders and hinder part of back are varied with large patches of whitish hair. The middle of the back between the shoulders has a very large patch of soft yellow hair, having a well-marked, narrow, black central streak, which commences with a triangular black spot on the upper edge of the yellow patch, and is continued into the white part of the fur on the loins. 


\section{Fur grey, elongate, faccid, sometimes very indistinctly marbled} with white blotches.

a. The male with a large yellow soft patch of hair on the back.

\section{Arctopithecus griseus. (Plate XXXVI.)}

Fur very long, greyish white, scarcely mottled; under-fur very long and abundant, black or white. Forehead and cheeks yellowish white; a broad band across the crown of the head and a broad streak from the orbits black. Male with a large yellow patch of soft hair in the middle of the back, with a broad central streak, and varied with blackish brown on the margins. Angle of the lower jaw broad, rounded, not produced beyond the back edge of the condyle.

Fig. 6 .

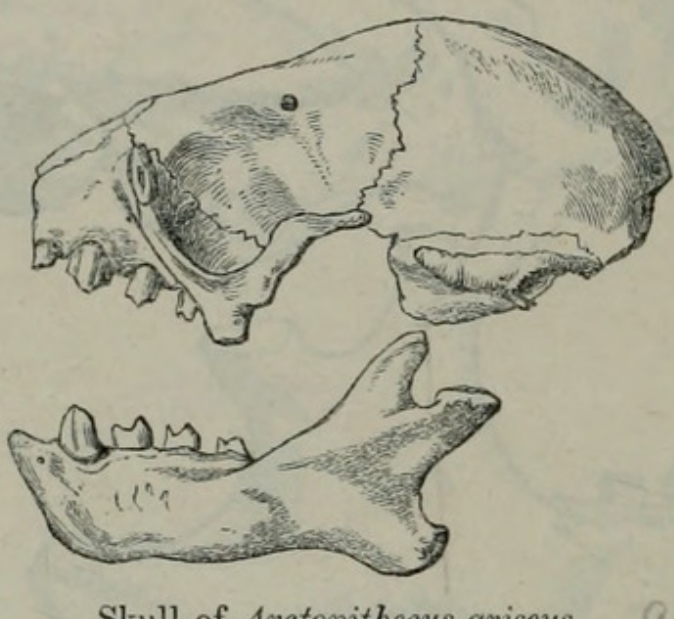

Skull of Arctopithecus griseus.

Arctopithecus griseus, Gray, Ann. \& Mag. N. H. 1871, vii. p. 302.

Hab. Costa Rica, Cordillera del Chucu, Veragua (Salvin).

The males and females have a more or less distinct dark dorsal spot, which is only visible when the animal is very carefully examined; and the general fur shows in some lights indefinite pale blotches on the back and limbs, which are produced by certain dark parts of the under-fur. The upper parts and sides of the head and neck dark brown ; the forehead, the cheeks, and chin white; this white colour occupies a less space of the chin and cheeks, and is less marked in the males than in the females or young. The black streak through the eye is distinct, is widened out on the sides of the face in the males, but is narrower behind and shorter in the female and young. The under-fur is very abundant and very soft, elongate, pure white, and with black or chocolate-brown in spots, producing rather a mottled appearance. Two of these white spots on the middle of the back are very distinctly marked in the female, and I at first thought they were a good character for a separate species; but I find, now the specimens are stuffed, that there are similar spots scattered over the bodies of all four specimens. The dorsal spot of the male is pale yellow with a very black central band, paler yellow 
PZS 1871 PL XXXVI.

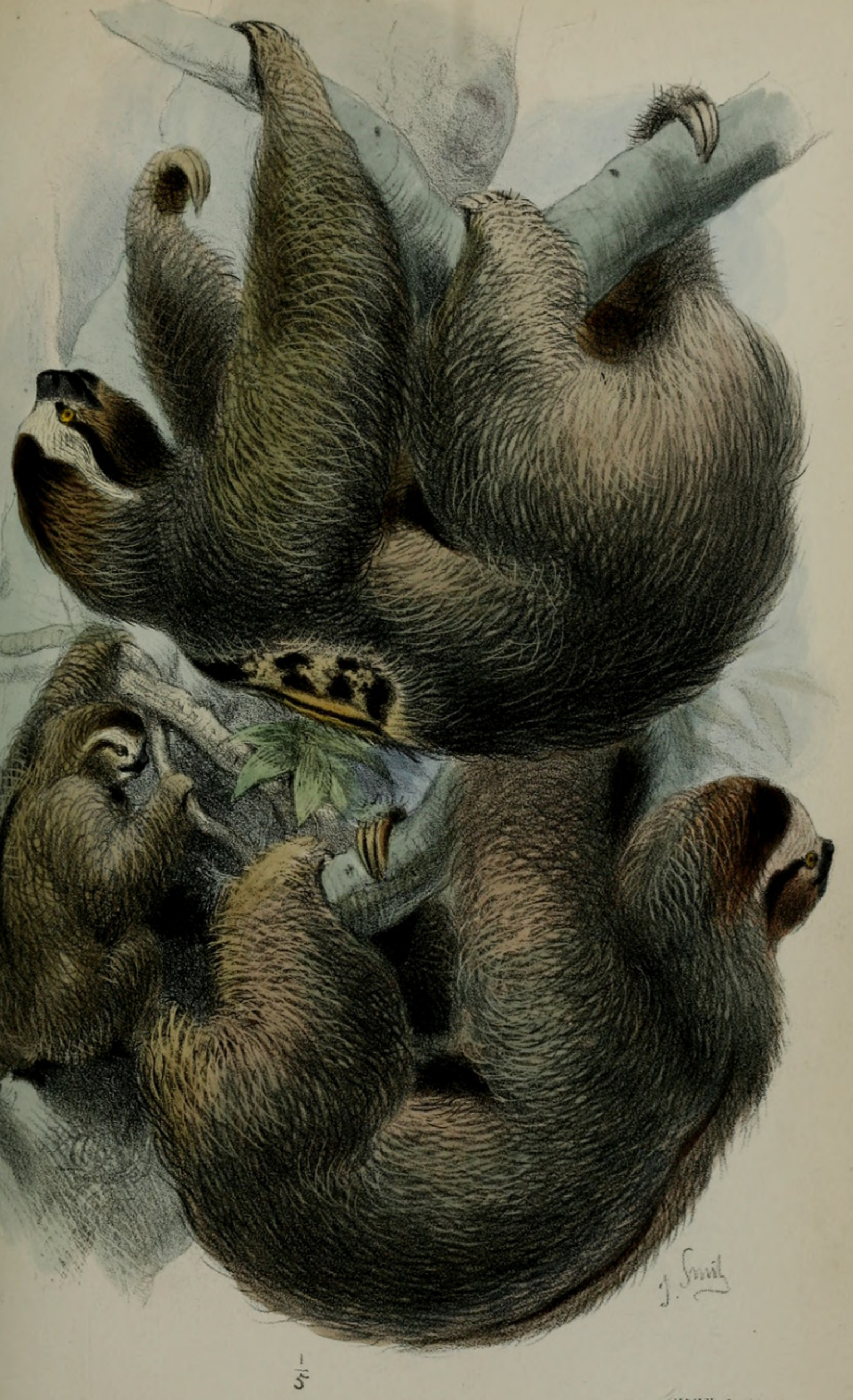

M\&N Hanhart imp 


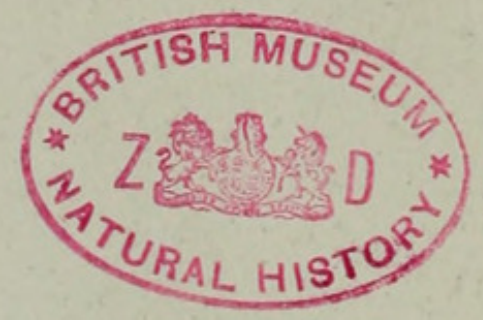


or nearly white on the edge, and marked with irregular unsymmetrical brown spots.

Bradypus ephippiger, Philippi, Archiv f. Naturg. 1870, p. 265, t. iii. 1, 2 (male and skull), is thus described :-

"The Museum of Santiago has just received a male Bradypus, of the division Arctopithecus, which likewise has a yellow nape-patch, but in general colour agrees neither with B. gularis nor B. cucullatus nor $B$. infuscatus. Its face is clothed with rather fine, short, close hairs, which are grey around the mouth and nasal openings, yellowish white on the cheeks and forehead, whilst a brownish black streak begins in front of the eye, goes over the ear, and gradually mingles itself with the brownish black colour of the neck. The hairs always become longer and more rigid the nearer they are to the neck. The hairs on the crown are brownish black, much stiffer and longer than those on the face, but not so long as those of the body, and so directed forward that they stand over the white forehead like a roll. The hairs under the chin are light brown, and become on the throat gradually longer and darker.

"The hairs of the body are more than two inches long, flat, some white, some grey-brown, so that on the sides and the extremities there is a somewhat piebald appearance, whilst those of the crown and occiput are dark brown, which colour gradually becomes lighter behind, palest and almost white on the underside of the belly. Between the shoulders and almost to the middle of the back there is a clear yellow patch, which is composed of thickly set hairs; in the middle it displays a black streak, and on each side at the edges, close to the long-haired fur, three round black spots. The moderately short hairs of these spots are very different from the long, coarse, flat, bristly hairs, also from the far longer, far finer and softer, perpendicular wool-hairs, which are everywhere beneath the bristly hairs, and are white on the light parts of the body, and ashgrey on the darker parts. Each foot has three white equal-length claws."

$H a b$. Uncertain. Brought to Santiago from either Guayaquil or Callao, probably obtained in Ecuador or North Peru.

The description and the figure, which is not very good, agree pretty well with the male Arctopithecus griseus obtained by Mr. Salvin from Costa Rica, and it is evidently nearly allied to that species; but, if the figure of the hinder part of the lower jaw be correct and of a perfect specimen, it is very different from any skull of Arctopithecus I have seen. The lower hinder angle is niuch produced behind, broad, triangular, nearly equilateral, with a bifid end. The skull of two of the older specimens of $A$. griseus are unfortunately imperfect in the hinder part; but that of a young specimen has the hinder angle broad, rounded, and scarcely produced. All the specimens of A. griseus in the British Museum have a much larger and broader eye-streak than represented in the figure; and the male has nearly the whole cheeks of a black colour, and not whitish, as described and figured. 
b. The male with a smail patch of soft white hair on the back.

\section{Arctopithecus flaccidus. (Plate XXXVII.)}

Fur elongate, flaccid, grey, very indistinctly marbled with white; under-fur very abundant, white and black in spots and blotches. Skull with a short broad nose. Lower jaw thick, short, high, thickened in front and very blunt; angle of lower jaw produced beyond the back edge of the condyle, rather broad (P.Z.S. 1849, t. xi. f. $1 a$ ).

Bradypus tridactylus?, Prince Maximilian, Abbildungen. Female and young.

Bradypus ai, Wagler, Isis, 1831 , p. 610 ?

Bradypus pallidus, Wagner, Suppl. iv. p. 143?

Arctopithecus flaccidus, Gray, P.Z.S. 1849, p.72, t.xi. f. I (skuli); Cat. Edentata, p. 365.

Hab. Venezuela (Dyson); Pará (J.P. G. Smith).

The figure of the skull, t. xi. f. 1, in the P.Z.S. 1849, represents the angle of the lower jaw as slender and acute; but the underside of the angle represented has been broken off, and the smaller figure, t. xi. f. $1 a$, represents the true form of this part. There is a skeleton in the Museum which I believe belongs to this species.

The two specimens in the Museum are probably males; but we have no means of determining the fact. They are both peculiar for the long, soft, flaccid hair, of a dull whitish-grey colour, without any indication of white or black markings, being only slightly grizzled by some of the hairs being whiter than the rest. There is a very abundant, rather long, very soft, blackish brown under-fur, and only a slight indication of a broad, short, blackish dorsal streak seen at the base of a deep concavity in the fur between the shoulders. This streak is much more visible in the specimen from Venezuela than in the smaller one brought by my son-in-law from Pará.

Prince Maximilian of Neuwied, in his 'Abbildungen,' has given a beautiful figure of a female Bradypus tridactylus, and its young one on its back, which is probably intended for A. flaccidus; for it has the long flaccid hair of this division; and he says the female has the longitudinal black streak in the woolly hair, and that the male has a longitudinal white line on each side of the back. Does he mean by this the small white central spot of soft hair between the shoulders, which is characteristic of this species?

Wagner refers this figure to his Bradypus pallidus; and the specific character may be only a travesty of Prince Maximilian's description, where he changes the white longitudinal streak into the back being longitudinally white-spotted, observing there is no orange fulvous dorsal spot, not thinking that the white stripes replace this patch in the other species-that is to say, if the figure represents A. flaccidus, which I think is probable; and it is the best published figure of the genus.

L'Aï, Cuvier, Oss. Foss. vol. v. t. vi. \& vii. (skeleton and skull).

A. problematicus, Gray, P.Z. S. 1849, p. 73, t. xi. f. 5 .

Bradypus problematicus, Gerrard, Cat. Bones Mam. p. 290. 


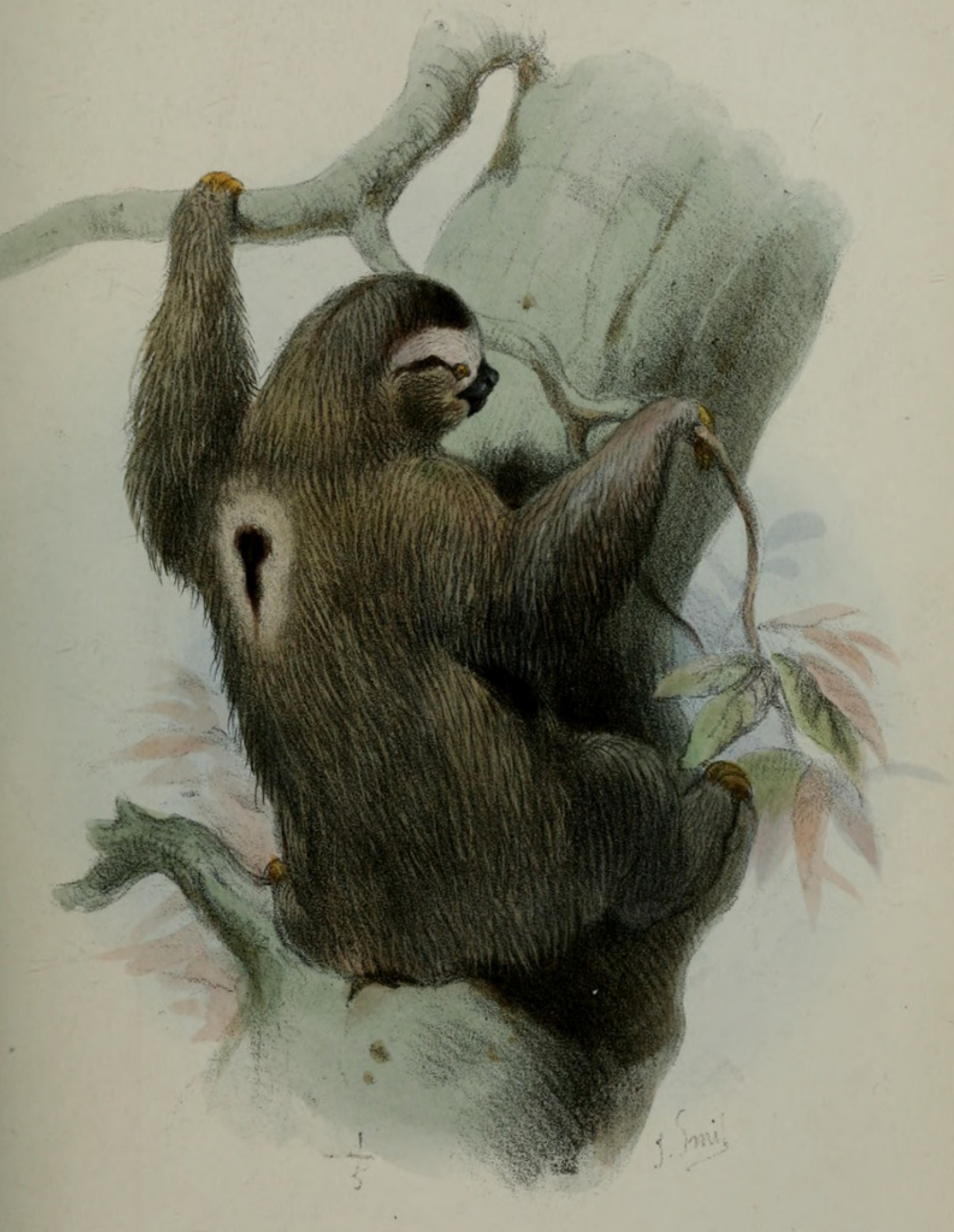



I have now little doubt that the figure of the skeleton by Cuvier and the skull which my son-in-law brought from Pará, on which I founded $A$. problemuticus, belong to A. Aaccidus. We have also a skeleton which appears to belong to the same species in the British Museum.

5. Catalogue of the Land-shells inhabiting Polynesia, with Remarks on their Synonymy, Distribution, and Variation, and Descriptions of New Genera and Species. By W. Harper Pease, C.M.Z.S.

[Received April 4, 1871.]

The geographical limits of Polynesia may be determined from the distribution of its land-shells, as distinctly as by that of its marine mollusca and zoophytes. They characterize it as being a distinct zoological province, separate from the East-Indian.

It is not only the largest in extent, but the most isolated in position of any on the surface of the earth. Stretching over nearly one fourth of the whole circumference of the globe, and from one extreme of the tropics to the other, it is separated by a wide expanse of ocean on three of its sides, north, east, and south, from the nearest provinces. On the extreme west, at the Pelew Islands, it comes into contact with the Philippines, and a short distance south, at the Samoas, with the Papuan Islands.

I do not propose to enter into a critical examination of the distribution and variation of the several genera and species, their relation to those inhabiting the neighbouring provinces and their probable origin, as it would involve the discussion of several collateral questions, such as the origin of the islands, their topography, formation of valleys, \&c., which I am not at present prepared to enter on.

As to general distribution I note the following facts. In West Polynesia, comprising the Pelews, Ladrones, Caroline, Ralick, and Radack groups, a few East-Indian types have entered, but do not prevail, the Polynesian predominating. Of Helices two species of the large Philippine forms occur, viz. H. pelewana, Pfr., at the Pelews, and $H$. sowerbyana, Pfr., at Hogoleu. All the others are of Polynesian types.

The genus Pitys, so prolific in species throughout all other parts of Polynesia, is not represented by a single species. Partula occur on all the islands.

Of operculated genera the East-Indian Diplommatinacea are represented by the genus Palaina at the Pelews, and one species at Ponape; they extend no further. All the species of Omphalotropis are of the East-Indian type, carinate at the umbilicus, and more or less varied with colours. One species referred to Cyclophorus and one to Cyclostomus, both of doubtful genera, have been found at

Proc. Zool. Soc.-1871, No. XXIX. 
Hogoleu. The genus Registoma is represented by a single species. All the above East-Indian forms occur on the most westerly islands, which have not been thoroughly explored; I anticipate that, when searched, they will yield a much larger proportion of Polynesian species, for the reason that these are of small size, and have escaped the notice of inexperienced collectors.

Passing south orer the Tarawan Islands (Kingsmill), all of which are low atolls, we arrive at the Samoas, the nearest group in Southern Polynesia to the Papuan Islands; it has yielded but a small number of species, although it has been explored by several persons within the past ten years*; they are all peculiar or of Polynesian types. Going on east to the Tahitian, Hervey, Austral, Paumotus, and Marquesan groups, comprising over one half of all the Polynesian islands, we find them inhabited by pure Polynesian forms.

The genus Partula here attains to its highest development; also Pitys and other genera of Helicince. All the operculated genera, with the exception of the cosmopolitan genera Helicina and Truncatella, are peculiar. The type of Omphalotropis, Pfr., does not extend to this part of Polynesia; but the genus is represented by several peculiar varieties which I have distinguished under the subgeneric names of Scalinella, Atropis, and Cyclomorpha.

The genus Diadema, Pse., is confined to the Hervey group; and Chondrella, Pse., is widely spread over the several islands. Two of the genera characteristic of the Polynesian fauna appear to have passed over to the Papuan Islands, viz. Partula and Pitys; of the former, nineteen species have been described from those islands. With one or two exceptions they are of simple bulimiform shape, and may not, at least all, prove to belong to the genus. Thirty-five or more species of Helices have been described from the Papuan Islands, Australia, New Zealand, and Tasmania, under the genera Patula, Discus, \&c., which are nearly related to the Polynesian genus Pitys. They are generally more planorboid in shape, with the aperture open and not laminate or dentate; their relation to the genus Pitys cannot be determined until the animals are examined and compared.

It appears, therefore, that while a few East-Indian types have entered and extend a short distance into Western Polynesia, as might be expected from their near contact on the south, the Polynesian genera have passed over to the Papuan Islands.

The Hawaiian Islands, on the northerly boundary of Polynesia, present several peculiarities in both their marine and land fauna, as might be supposed from their isolated position. Over two thirds of all the land-shells belong to the Helicterina, all of which are confined to that group of islands, as also the genera Carelia and Catinella. The several genera of Helicince are common with Southern Polynesia.

The only operculated genus is Helicina; while on the islands of Southern and Western Polynesia no less than sixteen occur. It is also the only locality in which the genera Blauneria, Pedipes, and Ophicardelus of the Melampinæ have been discovered.

* The Samoan Islands, in proportion to their size, are inhabited by a few more than one quarter of the number of species found at the Tahitian. 
As to general variation I note one fact. The species of most of the genera inhabiting Southern and Western Polynesia, ranging over a distance of more than 5000 miles from the Pelews to the Marquesas, vary less from a common type than those on the Hawaiian Islands, which are restricted in their distribution to 300 miles. Partula, the prevailing genus of Southern and Western Polynesia, occurring on all the high islands, presents so little variation that not a single subgenus has been proposed; while at the Hawaiian Islands the genus Helicter varies more on any one of the islands, even the smallest, but eight miles in length, than the Partula throughout their whole range. I select the two genera above in illustration, as the species are the largest in size, and comprise together nearly one half of all the land-shells inhabiting Polynesia.

I now offer a few remarks on the genera, adding to each descriptions of such species as I find in my collection to be new.

\section{Genus Pitys.}

Pitys, Beck, Index Molluscorum, 1837, p. 9.

The above genus was established by Dr. Beck on Helix oparica, Anton, from the collection made by the late Mr. Cuming at the island of Rapa (Opara), one of the Austral group, a few hundred miles south of Tahiti. There is no doubt as to the identity of the species, although it was described by Dr. Anton as H. oparica, from America.

By reason of the similarity between the shells of certain species discovered since and those of the European genus Discus, Fitz.= Patula, Held., all the Polynesian forms have been described under the European genus; with few exceptions the shells are quite distinct, and the animal decidedly so; they are most numerous at the Hawaiian and Tahitian Islands, less so at the Samoas, and altogether absent in West Polynesia.

The species are quite uniform throughout their whole range. The following are their general characters :-

"Shell orbicular or planorboid, finely radiately ribbed; spire but slightly elevated; last whorl rounded at its periphery and also at the umbilicus, more or less openly umbilicate, rarely imperforate; aperture generally dentate or laminate; radiately striped or tessellated on their upper surface with reddish brown and yellowish, the stripes occasionally taking a zigzag form on the periphery and base; rarely wholly reddish brown; generally covered with a thin epidermis, which, on a few species, supports short hairs."

Only three species, so far as known, are imperforate, and those the smallest of the genus, viz. imperforata, Pse., rotula, Jacq., and oparica, Anton; of the 37 species in the following catalogue, the aperture of 29 is dentate or laminate. The following is the only variation from the type as above:- $H$. stellula, Gld., inhabiting the Hawaiian Islands, is depressed, carinate at the periphery, and strongly ribbed, and of a shining texture.

At the Tahitian Islands a group of species of an aberrant form 
occur, represented by $H$. bursatella, Gld. They differ from the type in being angulate at the periphery, with the spire more elevated, and the whorls more plain. Their greatest peculiarity, and one by which they may be easily recognized, is the shape of the umbilicus, which becomes at maturity partly covered over by the base of the last whorl, thus becoming cavernous.

Two species have been described from Tahiti and the Hervey Islands, viz. jacquinoti, Pfr., and fratercula, Pse., which evidently belong to the above group, but are depressed and carinate at the periphery, corresponding in their variation to stellula, Gld., at the Hawaiian Islands. I add the following remarks on the synonymy of the species.

\section{Pitys bursatella, Gld.}

Of this variable species I have had an opportunity of examining several hundred specimens, and have also received a full series selected from the collections of the American exploring expedition, and from the late Mr. Cuming's type specimens of $H$. jacquinoti, Pfr. The synonymy, as determined by Dr. Gould on the labels of distribution issued by the Smithsonian Institution, and adopted in the following catalogue, is correct, with the exception of $H$. oceanica, Guill., and $H$. cavernula, Jacq. Of the synonyms determined as above, $H$. excavata, Jacq., and $H$. coarctata, Pfr., are pure synonyms of the type ; $H$. streptaxon, Roe, is an abnormal form, and $H$. turricula, Jacq., identically the same; $H$. oceanica, Guill., which I exclude from the synonymy, is described as being concavely depressed on its base ; and no mention is made of the laminæ in its aperture, which are distinct and could not have escaped notice. Should the determination by Dr. Gould prove to be correct, H. oceanica, Guill., should have precedence over $H$. bursatella, Gld., having been described four years previously.

H. jacquinoti, Pfr. (cavernula, Jacq.), differs from P. bursatella, Gld., or any of its varieties, in being more depressed, acutely carinate at the periphery, without epidermis (surface somewhat shining), its ribs solid, more prominent, extending over the edge of the whorls in a serrated manner, and all the whorls depressedly grooved concentrically at their middle. I have met with no species of its type in collections from the Marquesas, and refer it therefore to Tahiti with a doubt. The only other species of its peculiar form is $\boldsymbol{P}$. fratercula, Pse., inhabiting the Hervey Islands.

\section{Pitys jugosa, Migh.}

Helix jugosa, Migh. Proc. Boston Soc. 1845, p. 19.

Helix rubiginosa, Gld. Proc. Boston Soc. 1846, p. 171 ; Am. Exp. Ex. 1852, p. 50, fig. 49.

The above species ranges over all parts of the island of Kauai; it varies in being more or less openly umbilicate, and in the colour being either wholly reddish brown or tessellated with a dusky yellowish colour. 
To the above genus I add the following new species :-

Pitys atiensis, Pse.

T. orbicularis, tenuiuscula, aperte umbilicata, radiatim conferte et subarcuatim costulata, supra et infra flavido et rufo tessellatostrigata; spira vix elevata, apice obtuso, sutura bene impressa; anfr. 5, convexi, ultimus ad peripheriam basinque rotundatus; apertura subcircularis, obliqua ; perist. simplex, rectum.

Diam. 3, alt. $1 \frac{3}{4}$ mill.

Hab. Insula Atiu.

$P$. modicella (Fér.) is the nearest allied species, from which it differs in being more openly umbilicate, the spire more elevated, and the colours differently disposed.

Pitys rotellina, Pse.

T. planorboidea, solidiuscula, anguste umbilicata, tenuissime radiatim striatula, supra planiuscula, vix elevata, apice depresso : anfr. 6 , plano-convexi, ultimus ad peripheriam basinque rotundatus; apertura obliqua, lunaris, subcompressa, angusta; paries aperturalis lamella unica intrante munitus; perist. simplex, rectum; flavido et rufo alternatim undique strigata.

Alt. 1, diam. 2 mill.

Hab. Insula Aitutake.

\section{Pitys imperforata, Pse.}

T. imperforata, vel punctiformi-perforata, orbicularis, tenuiuscula, radiatim confertim et tenuissime costulata, flavido et rufo rudiatim tessellato-strigata, strigis ad peripheriam basinque flexuosis; spira plano-convexa, apice obtuso, sutura impressa; anfr. 6, plano-convexi, strictim et lente accrescentes, fere cequaliter, ultimus ad peripheriam rotundatus, basin plano-convexus; apertura obliqua, lunaris, lamellis 4-5 munita, 2 in pariete aperturali, 2-3 in margine basali; perist. simplex; columella callosa, vix eversa.

Diam 4, alt. 2 mill.

$\mathrm{Hab}$. Insula Aitutake.

Nearest allied to $P$. rotula, Jacq. It has more whorls, is distinctly radiately ribbed, and the reddish stripes extend over the base in zigzag shape.

\section{Pitys roratongensis, Pse.}

T. orbicularis, tenuiuscula, nitidiuscula, aperte umbilicata, radiatim conferte subflexuoso-costulata, flavido et rufo radiatim alternatim strigata, strigis ad peripheriam basinque undulatis; spira vix elevata, apice depresso, sutura bene impressa; anf $r .4 \frac{1}{2}$, rotundatoconvexi, leviter accrescentes, ultimus ad peripheriam basinque rotundatus; apertura obliqua, lunaris, lamellis 4 munita, 2 in pariete aperturali, 2 dentiformibus in margine basali ; peristoma columellaque simplicia.

Diam. $2 \frac{1}{2}$, alt. 1 mill.

$H a b$. Insula Roratonga. 
Pitys filocostata, Pse,

T. discoidea, late umbilicata, tenuiuscula, radiatim oblique et remote filocostata; spira depressa, planulata, sutura bene impressa; anfr. 4 , convexi, ultimus rotundatus, umbilicus $\frac{1}{3}$ diametri occupans; apertura vix obliqua, subcircularis; paries aperturalis lamellis 2 intrantibus munitus; perist. simplex, rectum; flavido et rufo alternatim strigata, strigis flexuosis, epidermide tenui induta.

Diam. 4, alt. 2 mill.

Hab. Insula Kauai.

Allied to P. hystrix, Migh. It may be distinguished at once by the thread-like character of its ribs, which are remote and shining white when the shell is in good order. It is also smaller, and the whorls are regularly convex. The radiating stripes are curved and flexuous.

Pitys analogica, Pse.

T. aperte umbilicata, solidiuscula, radiatim forte costata, costis ad peripheriam flexuosis, interstitiis transversim fere obsolete striatis ; spira fornicato-convexa, apice depresso, sutura valde impressa; anfr. 7 , rotundato-convexi, lente accrescentes, ultimus ad peripheriam late rotundatus; apertura vix obliqua, semilunaris, lamellis 7 coarctata, 2 parietalibus, 3 basalibus, 2 columellaribus; perist. simplex; flavido et rufo irregulariter radiatim strigata.

Diam $5 \frac{1}{2}$, alt. 3 mill.

Hab. Insul. Marquesas.

Pitys verecunda, Pse.

T. planorboidea, tenuiuscula, late umbilicata, radiatim regulariter tenuicostulata, supra planulata, sutura impressa; anfr. 6, convexi, ultimus ad peripheriam rotundatus, umbilicus fere $\frac{1}{2}$ diametri occupans; apertura late lunaris, lamellis 6 coarctata, 2 parietalibus, 3 basalibus, unaque columellari; perist. simplex; flavida, pallide rufo flexuoso-strigata.

Diam. 5, alt. $1 \frac{1}{2}$ mill.

Hab. Insul. Marquesas.

The above two species are the first of the genus discovered on the Marquesan Islands.

Genus Endodonta, Alb.

This genus was founded by Dr. Albers on $H$. lamellosa, Fér., which represents a group of species of peculiar characters inhabiting the Hawaiian Islands, and confined to that locality. Most authors have confounded it with Pitys (Beck), from which it differs in both shell and animal.

At the Tahitian Islands a group of species occurs nearly related to the above, which are also confined to that locality, none similar having been discovered in any other part of Polynesia. They are peculiar in being loosely coiled, and more widely umbilicate than any other species of Helicince; they are widely distributed over all the islands, and are more or less nearly related to each other and to the 
above genus. I note that acetabulum, Pse., should be compared to ficta, Pse., rather than obolus, Gld., as is done by Dr. Pfeiffer. I add the following new species :-

Endodonta celsa, Pse.

T. orbicularis, solidiuscula, late umbilicata, tenuissime radiatim creberrime striatula, rufo et albido pallide tessellata ; spira elevata, apice obtusiusculo, nucleus ruf escenti-fuscus, sutura bene impressa; anfr. 7, convexi, interdum concentrice elevato-striati, rarissime sulcati aut angulati, ultimus ad peripheriam obtuse angulatus, subtus rotundatus; apertura obliqua, fere circularis, lamella unica in anfr. penultimo munita.

Diam. 7, alt. $3 \frac{1}{2}$ mill.

Hab. Insula Raiatea.

\section{Genus Microcystis.}

Microcystis, Beck, Index Molluscorum, 1837, p. 2.

Dr. Beck enumerates six species in illustration of the above genus, three inhabiting the West Indies and three Polynesia. The former are $H$. cubensis, Pfr. =trifaciella, Beck (also the type of the genus Cystycopsis, Mörch), H. pellicula, Fér., locality doubtful, but of West-Indian form, and $H$. pictella, Beck, which remains undetermined. These species are globose in shape, ornamented more or less with coloured bands, of a West-Indian type well-known to collectors.

The Polynesian species are $H$. ornatella, Beck, adamsii, Pfr.= filiceti, Beck, and amæenula, Beck, to which I have lately added a beautiful little species from the Marquesas Islands, viz. marquesana, Pse. The above are much smaller than the West-Indian species, and not so globose, excepting the last, and will not, in my opinion, prove to be congeneric with them. They stand as anomalies in the Polynesian fauna, being confined to islands in the extreme easterly portion of Polynesia, and are not represented elsewhere.

It is not improbable that the three species cited by Dr. Beck from Polynesia are varieties of one, as they are all reported from Rapa, a very small island (but $6 \frac{1}{2}$ miles long) in the Austral group, about 400 miles south of Tahiti.

Dr. Pfeiffer credits adamsii, Pfr., to both Rapa and Pitcairn, which is probably an error. If it occurs at Pitcairn, it is without much doubt distinct from Dr. Beck's species.

Authors have lately extended this genus to embrace a variety of forms, especially a large group of thin, fragile, glassy species, widely distributed over the Polynesian and Papuan Islands, and extendiug to Australia. They appear to have overlooked the fact that Dr. Beck recognized them as being distinct from Microcystis, and arranged them under the generic name of

\section{Helicopsis, Beck.}

It was injudicious on the part of Dr. Beck to adopt the above name, as it had been used previously by Fitzinger, although the 
latter proved to be a synonym of Theba, Leach. He cites four species as types: the first, H. corne, I do not find mentioned by any other author, and has not been published; the three remaining are from Polynesia and agree in their characters, leaving no doubt as to the genus intended; they are brunnea, Anton,=glandula, Beck, subtilis, Anton, = vitrinella, Beck, and orbis, Beck.

The animal of the speeies I have had an opportunity of examining is rather slender and elongate, tapering gradually posteriorly to a point, and provided with a glandular opening, slightly raised, at about an equal distance between the extremity of the foot and the shell; the mantle wholly included within the shell. They should therefore be arranged in the family Stenopida, under the genus Ariophanta, rather than Nanina.

The species enumerated in the following catalogue vary considerably from the type; their generic relations cannot be determined until the animals have been examined. The columella of the typical species is simple, oceasionally slightly everted; in others it is more or less callous, sometimes dentately so, or the callosity is transverse to the columella.

The type is a depressed form, orbicular in shape, either rounded at the periphery or slightly angulate; other species are acutely angulate, assuming a trochiform shape, one form of which M. Mousson has lately separated under the generic name of Trochonanina. Other species assume a conical shape, such as H. cultrata, Gld., and conula, Pse., which would, by some authors, be ranked under the European genus Conulus.

\section{Genus Trochomorpha, Alb.}

Trochomorpha trochiformis, Pfr.

The above is one of several Férussacian species which appear by name in his 'Prodrome,' of which the types are probably lost, as they are not described in his great work on land-shells, nor recorded by M. Deshayes. The first description of the above is that by Dr. Pfeiffer, from a Tahitian species, which is generally accepted as the type, although the locality given by Férussac is the island of Mauritius.

As there is at least a doubt as to the species originally named by Férussac, I think proper to attach the name of Dr. Pfeiffer to the above as author.

I have received several distinct species from collectors under the name trochiformis, Fér.

Dr. Pfeiffer's type inhabits the island of Raiatea. It occurs of larger size, and occasionally wholly dark brown or wholly pale yellow ; a variety is rarely met with more depressed than the type, of a whitish or pale yellow colour encircled by a single narrow dark brown line or band; base ornamented the same. On the island of Moovea, where the species also occurs, this variety prevails and assumes the size and shape of the type.

On Tahaa, adjoining Raiatea, the type occurs of smaller size and more conical in shape. 
The variety referred to above I distinguish by the name of

Trochomorpha trochiformis, var. pallens, Pse.

Testa plerumque depressior, albida aut pallide straminea, linea unica rufescenti-fusca cingulata.

Trochomorpha nigritella, Pfr.

The above has been credited by Dr. Pfeiffer to the Sandwich Islands, which is an error. No species of its type or genus inhabits that locality ; it is confined to Ponape, Caroline Islands.

A distinct variety occurs so remote from the type that it was returned to me by the late Mr. Cuming marked $\boldsymbol{H}$. trochiformis, Fér. I describe it as

\section{Trochomorpha nigritella, var. oppressa, Pse.}

T.umbilicata, solida, trochiformis, depressa, apice obtusa ; anfr. 6-6 $\frac{1}{2}$, planiusculi, lente accrescentes, irregulariter oblique tenuistriati, ultimus acute carinatus, basi convexus; apertura securiformis; perist. simplex, incrassatum, interdum marginibus callo junctis; flavescens, juxta suturam fascia rufescenti-fusca cingulata, basi rufescenti-fusca, margine favescente.

Diam. $13 \frac{1}{2}$, alt. 6 mill.

Hab. Insula Ponape.

The above differs from the type in being more trochiform in shape, with the whorls nearly flat and smoother, and also in colour.

Trochomorpha contigua, Pse.

Trochomorpha congrua, Pse, Am. Journ. Conch. vol. iv. 1868, p. 154.

Name preoccupied, changed as above.

Trochomorpha exclusa, Hombr. non Fér.

Trochomorpha exclusa, Voy. au Pôle Sud, p. 24, pl. 7. f. 14-17.

The above, collected at the Tahitian Islands, is Swainsonii, Pfr., and should not be connected with the Papuan species.

\section{Genus Partula, Fér.}

Having in preparation a monograph of the above genus in which the distribution and variation of its species will be fully treated of, I merely record descriptions of the following new species :-

Partula pellucida, Pse.

T. oblongo-ovata, anguste perforata, tenuis, pellucida, striis longitudinalibus transversisque granulosa; spira conica; sutura impressa, marginata; anfr. $4 \frac{1}{2}$, plano-convexi, ultimus $\frac{1}{2}$ longitudinis testa haud aquans; apertura verticalis, ovata; perist. subincrassatum, album, vix expansum; columella supra vix dilatata, fere recta; albido-cornea. 
Long. 12, diam. $6 \frac{1}{2}$ mill. Apert. long. 5, diam. $3 \frac{1}{2}$ mill.

Hab. Guadalcanar, insul. Solomon.

This delicate little species was collected at the above locality by John Brazier, Esq.

It is the nearest allied to P. minuta, Pfr. It differs in being more slender, thinner, the spire elongate, the aperture smaller, the surface more distinctly granulose, and the suture marginate.

Partula faba, var. subangulata, Pse.

T. anguste perforata, dextrorsa, conico- interdum abbreviato-ovata, solida, levigata, striis incrementi notata, rufescenti-fusca, juxta suturam fascia favescente cingulata, vel favescente, fascia fusca ad suturam, interdum omnino straminea aut flavescente aut rufescenti-fusca; anfr. 6, convexi, ad suturam subangulati, ultimus plerumque tumidiusculus; columella superne tuberculato-callosa, late dilatata; perist. intus callosum, late expansum, margine dextro tuberculato-calloso, superne sinuato, fuscum, callo albido; apertura oblongo-ovalis, subauriformis.

Alt. 28, diam. 15 mill.

Hab. Insula Tahaa.

The metropolis of $\boldsymbol{P}$. faba, Mart., is on the island of Raiatea ; on the adjoining island, Tahaa, it occurs in a modified form, which we distinguish by the above name.

\section{Subfamily Succineinæ, H. \& A. Adams.}

Previously to the publication of the report of the American Exploring Expedition but three species of Succinea were known as inhabiting Polynesia. At the present time it may rank as the metropolis of the family, not only as regards the number of its species but also types. The number will be much increased, that of the Hawaiian Islands at least four-fold.

It is impossible to define their generic, much more their specific limits, without a knowledge of the animals. However closely the shells inhabiting distant provinces may resemble each other, it will eventually appear that the genera in this family are as local in their distribution as those of the Helicterina.

The animal of Succinea picta, Pfr., inhabiting St. Helena, given by $\mathbf{H}$. and A. Adams as the type, differs certainly from the European genus.

It is also doubtful whether any species of the genus Helisiga inhabits Polynesia. I have met with no animal corresponding to the original type of that genus. I would note that the character given to the Hawaiian species arranged under the above genus by $\mathrm{H}$. and A. Adams, viz. "the mantle-margin covering the outer lip," I have not observed, nor does it appear on the figures in the Report of the American Exploring Expedition.

I class for the present all the Polynesian species under the genus Succinea, with the exception of two forms at either extreme of the family : the one, Catinella, has been heretofore classed with Oma- 
lonyx ; and the other is distinct both as to shell and animal. They are as follows :-

\section{Genus Catinella, Pse.}

T. tenuis, fragilis, planulata, depressa, scutellaformis, ovalis ; spira minuta, rudimentalis, immersa, subtus concentrice sulcata; apertura perampla, magnitudinem testa fere aquans.

The type of the above genus is $C$. rubida, Pse. (Journ. de Conch. 1870 , p. 97), to which should be added Succinea explanata, Gld., both inhabiting Kauai, to which island the genus appears to be restricted.

The animal of the genus Omalonyx, inhabiting South America, is described as being semiaquatic in its habits, being found in marshes and dying when removed from the vicinity of the water. The habits of the species of the above genus are quite the reverse. They are strictly arboreal, living on the leaves of banana and other low bushes, and dying when washed by heavy rain down into the axils of the leaves holding water. The shell is attached to the animal by a ligament, for which there is a groove provided around the underside of the spire. It is but loosely attached, and may be removed from the animal while living, without apparent injury. Having unfortunately lost my notes of the animal, its description must be deferred.

\section{Genus Truella, Pse.}

Typus, Succinea elongata, Pse., Journ. de Conch. 1870, p. 96.

T. elongata, gracilis, tenuis ; spira elongata ; anfr. celeriter accrescentes; apertura posterior contracta, acuta, antice dilatata; anfr. ultimus postice convolutus.

The above peculiar type has been heretofore only known as inhabiting the Tahitian Islands, where it is represented by Succinea procera, Gld., and $\boldsymbol{S}$. infundibuliformis, Gld. A species was unexpectedly discovered on the island of Kauai during the past year, in which the peculiarities of the genus are the most strongly expressed, and which I adopt as the type.

The shell is elongate, slender posteriorly, spire elongate, whorls rapidly enlarging; aperture contracted posteriorly by the convolution of the last whorl.

The animal is slender, tentacles small, cylindrical, gradually tapering to a slightly enlarged tip.

Succinea mammillata, Pse.

T. tenuiuscula, suboblique ovata, striis incrementi confertim et tenuiter notata, rubella aut succineo-rubescens; anfr. 3 , ultimus tumidiusculus, vix obliquus; anfr. spirce convexi, apice mammillato, sutura valde impressa; apertura oblongo-ovalis, fere recta, labro incrassato, rufo; columella margine cullosa, vix arcuata, plica conspicua.

Alt. 12, diam. $7 \frac{1}{2}$ mill.

$H a b$. Insula Nukuhiwa. 
The above is the first species described from the Marquesas group of islands.

The shell is rather thin, somewhat obliquely ovate, finely and closely marked by striæ of growth, of a reddish or reddish horncolour; whorls three, the last slightly swollen and rather oblique; whorls of the spire convex, the apex mammillary, suture strongly impressed; aperture oblong-oval, almost vertical; lip thickened on its edge, red ; columella but slightly curved, margin thickened, distinctly plicate posteriorly.

\section{Succinea rubella, Pse.}

T. tenuis, suboblique ovata, striis incrementi tenuiter rugosula, succineo-rubescens ; anfr. $2 \frac{1}{2}$, uitimus convexus, obliquus ; anfr. spirce rotundato-convexi, apice papillari; sutura bene impressa ; apertura fere recta, acute ovata, labro tenui, columella arcuata, margine incrassato; perist. simplex, marginibus callo tenui junctis.

Alt. 12, diam. 7 mill.

$H a b$. Insula Lanai.

Genus Tornatellina, Beck.

Tornatellina gracilis, Pse.

T. elongata, gracilis, tenuis, nitida, lavigata, striis incrementi tenuissime notata, fusco-cornea; anfr. 5 , convexi, ultimus planulatus, interdum medio concentrice sulcatus; apertura parva, acute ovata; lamina parietalis valida, prominens; columella forte callosa, tortuosa.

Alt. $3 \frac{3}{4}$, diam. $1 \frac{1}{2}$ mill.

Hab. Insula Kauai.

Tornatellina dentata, Pse.

T. oblongo-ovata, tenuis, fragilis, nitida, lavigata, fulvo-cornea; anfr. $4 \frac{1}{2}$, convexi; sutura impressa; apertura parva, acute oblongo-ovata; lamina parietalis valida, compressa, prominens; columella forte callosa, tortuosa, vix compressa, medio dente prominente munita.

Alt. $2 \frac{1}{2}$, diam. $1 \frac{1}{4}$ mill.

$H a b$. Insula Hawaii.

The peculiarity of this little species is, that the columella, in addition to the usual callosity, which in this species is somewhat compressed, is furnished with a prominent tooth on its middle.

Tornatellina striata, Newc., described in Proc. Cal. Acad. 1861, p. 93, I exclude from the genus, transferring it to the genus Leptachatina, Gld.

\section{Genus Vertigo, Müller.}

Dr. Gould remarked in his description of $V$. tantilla, in the 'Report of the American Exploring Expedition,' that it was the first species of its type he had met with from Polynesia. It has 
been discovered since that the species abound on all the islands of the several groups, even on the low sandy Atolls.

So far as known, they may be arranged in three groups, viz.:first, $V$. nitens, Pse., \&c., white, pellucid, nearly smooth; second, $V$. lyrata, Gld., striatula, Pse., \&c., generally oblong in shape, distinctly ribbed, aperture campanulate, modified by the transverse grooves on last whorl; and third, $V$. costulosa, Pse., more abbreviate in shape, sometimes nearly globular, finely ribbed or elevately striate, and aperture nearly circular.

The following are new species.

Vertigo striatula, Pse.

T. cylindracea, oblonga, solidiuscula, sinistrorsa, umbilicata, longitudinaliter oblique et flexuose forte costata, interstitiis transversim tenuiter striatis; anfr. 5 , rotundato-convexi, plerumque medio rotundatim angulati, ultimus vix porrectus, medio concentrice late sulcatus, circa umbilicum rotundato-angulatus, basi compressus; apex obtusus; sutura bene impressa ; apertura subquadrangularis, basi rotundata, lamellis 3 coarctata, in pariete aperturali 2, primo magno, cum labro continuo, secundo mediano, interno, in margine columellari superne 1 , ad labium juncta; peristoma continuum, crassiusculum, vix expansum et reflexum, labro postice sinuoso; rufo-castanea, costis albidis.

Alt. $2 \frac{1}{2}$, diam. $1 \frac{1}{2}$.

Hab. Insula Hawaii.

Vertigo armata, Pse.

T. ovata, vix oblonga, nitidiuscula, dextrorsa, perforata, longitudinaliter tenuissime striata, interdum remote, tenuiter filo-costata, sub lente subtilissime granulosa, fulvescenti-cornea, filis albidis; anfr. $4 \frac{1}{2}-5$, rotundato-convexi; apex obtusus; apertura subquadrangularis, fere circularis, dentibus 8 munita, in pariete aperturali 3, primo maximo cum labro continuo, secundo mediano, intrante, tertio minimo, interno, in margine columellari 1 , in marginibus basali et labiali 4, profunde sitis; peristoma incrassatum, rufescens, subexpansum, reflexum, marginibus disjunctis, labro postice vix sinuoso.

Alt. 2, diam. $1 \frac{1}{4}$ mill.

Hab. Insula Bolabola.

Vertigo simplaria, Pse.

T. tenuis, obeso-ovata, dextrorsa, rimata, favescens, longitudinaliter tenuiter striata; anfr. 3 , rotundato-convexi, ultimus planulatus; sutura valde impressa; apex obtusus; apertura fere circularis, edentata; peristoma tenue, marginibus disjunctis; columella superne patula, vix expansa.

Alt. $1 \frac{3}{4}$, diam. 1 mill.

Hab. Insulæ Marquesas.

Vertigo costata, Pse.

T. cylindracea, oblonga, solidiuscula, dextrorsa, rimato-perforata, 
longitudinaliter flexuose forte costata, rufescens; anfr. 4, rotundato-convexi, ultimus concentrice valde bisulcatus, basi compressus; apex obtusus; sutura valde impressa; apertura campanulata, basi rotundata, lamellis 4 munita, in pariete aperturali 2 , primo cum labro continuo, secundo mediano, intrante, in margine basali 1, labiali postice 1, labro flexuoso ; peristoma tenue, marginibus disjunctis.

Alt. 2, diam. 1 mill.

Hab. Insula Hawaii.

Vertigo perlonga, Pse.

T. elongata, cylindrica, rimato-perforata, dextrorsa, pallide straminea, longitudinaliter filo-costata, costis obliquis, remotis, flexuosis; spira obtusa; sutura impressa; anfr. 5, planulati, ultimus medio concentrice sulcatus, prope basin indentatus; basi compressus, circa umbilicum rotundato-angulatus; apertura subquadrangularis, vix porrecta, basi contracta, rotundata, postice bilamellata, labro superne sinuoso, unilamellata; peristoma continuum vix eversum.

Alt. $2 \frac{1}{2}$, diam. 1 mill.

$\mathrm{Hab}$. Insula Oahu.

Vertigo dentifera, Pse.

T. cylindrica, solidiuscula, perforata, dextrorsa, longitudinaliter oblique tenuissime striata, rufo-aut flavo-castanea; anfr. 4, convexo-rotundati, ultimus prope labrum brevi-bisulcatus; apertura fere circularis, postice biplicata, columella uniplicata, basi trivel quadridentata, labro vix reflexo; peristoma crassiusculum, non continuum.

Alt. $1 \frac{3}{4}$, diam. 1 mill.

$\mathrm{Hab}$. Insula Roratonga.

Vertigo costulosa, Pse.

T. obtuso-ovata, interdum fere globosa, tenuis, perforata, dextrorsa, vix nitida, oblique et sparsim filo-costata; anfr. 4, rotundatoconvexi, tumidi, ultimus prope labrum, interdum brevi-bisulcatus; apex obtusus; sutura valde impressa; apertura fere circularis, dentibus 5-6 coarctata, in pariete aperturali 2, primo juxta labrum, secundo maximo, prominente, lamelliformi, intrante, in margine columellari 1, in marginibus basali et externo, 2-3 profundo sitis; peristoma subreflexum, crassiusculum, marginibus plerumque callo junctis; rufo-vel flavo-cornea.

Alt. $1 \frac{3}{4}$, diam. 1 mill.

Hab. Insula Hawaii.

Vertigo bacca, Pse.

$T$. cylindracea, abbreviata, tenuiuscula, dextrorsa, perforata, lavigata; apex obtusus; anfr. 4, rotundati, ultimus concentrice bisulcatus; apertura fere circularis ; in pariete aperturali bilamellata, columella unidentata; labrum vix eversum; pallide fusca.

Hab. Kalapana, Insula Hawaii. 
The above description was drawn up several years since from specimens collected at Kalapana, district of Puna, Island of Hawaii ; as they have been lost, I furnish the precise locality, to enable collectors to recover the type.

Before leaving this genus I would remark that, of the first type referred to above, three species have been described, viz. $\boldsymbol{V}$. nitens, Pse., pediculus, Shutt, and nacca, Gld. They are widely distributed, specimens having been received from the following islands :-Apaiang, Ebon, Upolu, Aitutake, Roratonga, Tahiti, Bolabola, Raiatea, Nukuhiwa, Hawaii; they agree in their general characters as to size, shape, texture, and colour, with slight local variations. At some localities they are wholly dextral, at others wholly sinistral. They differ more widely as to the number and position of the teeth in the aperture: usually there are two teeth on the posterior wall of the aperture, which are separate or joined in a bifid manner, rarely but one ; the columellar tootb is constant; on the base of the outer lip, generally three, at regular intervals, occasionally but two ; and in addition very small rudimentary teeth are rarely met with at different parts of the aperture.

Having received but forty or fifty specimens, I am at present unable to offer a decisive opinion as to the value of the several species.

I note also that $V$. tantilla, Gld., occurs on all the islands of the Tahitian group, and $V$. costulosa, Pse., on all those of the Hawaiian. The species of this genus will prove to be more widely distributed than those of any inhabiting Polynesia.

\section{Operculated Genera.}

\section{Genus Omphalotropis, Pfr.}

Since the publication of a monograph of the above genus in 'Journ. de Conch.' 1869, a number of species have been described which confirm the distribution and variation as there given.

The typical form of the genus, the shells of which are carinate or angulate around the umbilicus, more or less ornamented with colours, and of an ovate shape more or less modified, enters Western Polynesia from the East Indies, extending south to the Samoas and thence over the Papuan Islands. Passing east, however, to the Tahitian group and the other islands of Eastern and Southern Polynesia, the genus undergoes a wide variation, so much so that several of the species have been classed with other genera.

Their operculum and animal clearly connect them with the above genus. One of the forms I have distinguished by the subgeneric name Scalinella, which may be found faithfully illustrated on Plate 7, Journ. de Conch. 1869. One remaining I now separate under the name of

\section{Subgenus Atropis, Pse.}

Testa oblonga, interdum cylindracea, rare ovata, imperforata vel anguste perforata, unicolor; apertura ovata, fere circularis; 
perist. simplex, continuım, ad anfr. penultimum adnatum aut disjunctum, interdum vix porrectum; anfr. ultimus sape ad peripheriam subangulatus.

Animal operculumque gen. Omphalotropis, Pfr., persimilis.

The shell of this genus is elongate, sometimes cylindrical, rarely. ovate, imperforate, in the species of ovate form narrowly perforate; aperture ovate, occasionally circular; peristome continuous, sometimes disconnected from the penultimate whorl and very slightly porrected. The last whorl is frequently obtusely angulate on its periphery, of one colour, usually pale yellow or reddish.

The species furthest removed from the type of Omphalotropis, viz. $A$. viridescens, Pse., and ventricosa, Hombr., can scarcely be distinguished from genus Blanfordia, A. Ad.; those approaching the nearest, vescoi, Dohrn, \&c., are of small size, narrowly perforate, abbreviately ovate, but wanting the angulation around the umbilicus. In the following catalogue they are separated from the typical forms.

\section{Genus Cyclomorpha, Pse.}

Typus, Cyclostoma flavum, Brod. P. Z. S. 1832, p. 59.

Testa turbinata, subglobosa, solida, lcevigata aut spiraliter striata, perforata; apertura fere circularis ; peristoma simplex, subincrassatum, callo tenui continuum.

Operculum ei gen. Omphalotropis, Pfr. similis.

The shell of the above genus differs widely from any of the genera of the subfamily Realiea, Pfr. From its similarity to those of the genus Ostodes, Gld., the species have been heretofore included by Drs. Pfeiffer and Gould in that genus. Having received a number of specimens collected alive with the operculum, I discover it to be certainly related to the above subfamily and to Cyclostomina; while the genus Ostodes belongs to the subfamily Cyclophorina. I also notice that Ostodes œenomphalus, Phil., arranged by Dr. Pfeiffer next to C. Aavum, Brod., and included by Dr. Gould in his genus Ostodes, is described as being carinately angulate around the umbilicus, one of the peculiar characters of the genus Omphalotropis.

It should be connected with the above genus, serving to confirm its position in the subfamily Realiea, Pfr.

Its locality is unknown; the other species inhabit the extreme easterly portion of Polynesia.

Having had an opportunity of examining the operculum of three species of the genus Ostodes, I extend the description given by Dr. Gould as follows :-

\section{Genus Ostodes, Gld.}

Ostodes, Proc. Bost. Soc. vol. viii. 1861, p. 283.

Operculum tenue, membranaceum, circulare, margine tenuissimo, lacerato ; extus fornicato-convexum, nitidum; multispirale; anfr. 8-10, lente accrescentes, fere aquales; sutura linearis, nucleo centrali; apex vix elevatus, papillatus; subtus regulariter concava. 
Genus Chondrella, Pse.

Typus, Cyclostoma parvum, Pse. P. Z. S. 1864, p. 674.

Testa globoso-conica, tenuiuscula, striata, imperforata, vel vix rimata; apertura fere circularis; peristoma simplex, tenue, marginibus late disjunctis; columella callo appresso, late dilatato induta, locum umbilici tegens.

Animal tentaculis nullis, oculis supra caput immersis.

Operculum testaceum, solidiusculum, pallidum, nitidum, oblongoovatum, latere dextro fere recto, utrinque rotundatum; extus planum, lavigatum, nucleo obsoleto, marginibus anterioribus et lateralibus angulatis; subtus vix concavum, margine rotunde calloso, quasi costato.

The above genus is peculiar in all respects, animal, shell, and operculum. It should be classed with Helicinida. It is widely distributed over the islands of Southern Polynesia. Most common at the Hervey group, where Mr. Garrett has had ample opportunity of examining the animal alive. It has positively no tentacles, the eyes being immersed on the head in the situation usually occupied by tentacles.

Cyclostoma minutissimum, Sow., the generic position of which has been undecided, belongs to this genus. It inhabits Pitcairn Island.

\section{Genus Palaina, Semp.}

Palaina, Semp. Journ. de Conch. 1865, p. 291.

Pupoidea, Pse. Am. Journ. Conch. 1865, p. 289.

The two genera above are no doubt synonymous. As there appears to be a difference of opinion as regards the relation of this genus to those of the Diplommatinacea, by reason partly of a want of knowledge of the characters of its operculum, I furnish the description of that of $\boldsymbol{P}$. scalariformis, Pse., inhabiting the Caroline Islands.

Operculum membranaceum, circulare, multispirale; anfr. 4-5, lente accrescentes, sutura lineari; extus nitidum, medio depresso-concavum, anfr. ultimus rotundatus, margine tenui; subtus vix concavum.

The outer side is regularly concave to the last whorl, which is rounded, so that the operculum when laid down would rest on its margin.

It requires repeated efforts and careful manipulation to separate an operculum, an eighth of a millimetre in diameter, from the animal. If macerated in water until the animal matter becomes soft, the operculum is liable to fall to pieces; while it is impossible to separate it from the animal in a dried state. I have been successful in obtaining the opercula of all the genera inhabiting Polynesia, excepting Electrina, Gray, of which I have seen no specimens.

\section{Genus Helicina, Lam.}

Under this genus I merely record the following descriptions and synonyms.

Proc. Zool. Soc.-1871, No. XXX. 
The following species, credited to Polynesia, I exclude from the catalogue, viz. :-

H. crassilabris, Phil., does not inhabit the Sandwich Islands.

$H$. bicolor, Pfr., is credited to Tahiti, which is without much doubt an error, as no species of its size inhabits Polynesia except $H$. mangeria, Gray, from which, or any of its varieties, it differs widely.

\section{Helicina maugerie, Gray.}

The type of this species is a thick solid shell, rather bluntly angulate at the periphery, and may always be recognized by the colour of its basal callosity, bright yellow, which is persistent; the basal callosity of the variety H. rubicunda, Pse., is equally persistent, of a dark red. On both the callosity is very thick.

At the same locality a form occurs which I consider a variety of the above, although it differs rather widely in most of its characters ; it is more depressed, acutely angulate at the periphery, white or whitish in colour, encircled above by one or two narrow reddish lines, apex usually pale yellow, and the basal callosity thin and white. I distinguish it by the name of

Var. albinea, Pse.

T. crassa, lenticularis, sublavigata, vix nitida, tenuissime radiatim et arcuatim striata, albida, supra lineis 1-2 rufescentibus cingulata, infra albida; spira depressa, obtusa, plerumque pallide favescens; anfr. 5 , planulati, indistincte marginati; ultimus basi convexus, subtus ad peripheriam distincte marginatus; apertura lunaris, intus pallide straminea; peristoma intus callosum, albidum; callus basalis tenuis, albidus.

Diam. $12 \frac{1}{2}$, alt. $5 \frac{1}{2}$ mill.

$H$. maugeria, Gray, and all its varieties, occur only on the island of Raiatea.

\section{Helicina calliostoma, Pse.}

T. crassa, globoso-conoidea, tenuissime radiatim striata, omnino pallide straminea aut albida, interdum rufescente fasciata vel maculata; spira vix elevata, conoidalis; sutura bene impressa; anfr. 5-6, plano-convexi, ultimus ad peripheriam rotundatus, basi convexus; apertura obliqua, lunaris; columella brevis, incrassata, supra vix dilatata, cum perist. angulum acutum formans ; peristoma valde incrassalum, interdum duplicatum, album, vix expansum et eversum, marginibus late disjunctis; callus basalis tenuis, parvus, albidus.

Alt. $7 \frac{1}{2}$, diam. $7 \frac{1}{2}$ mill.

$H a b$. Insulæ Marquesas.

The colour of this species is probably much more varied than noted above.

Helicina tahitensis, Pse.

Helicina pisum (Hombr. non Phil.) Voy. Pôle Sud, vol. v. p. 44, pl. 11. f. 18-22. 
T. globoso-conoidea, crassa, tenuissime radiatim striata, omnino straminea aut albida, interdum rufescens, juxta suturam straminea, apex semper straminea; spira conoidea, convexa, obtusa; anfr. 5 , convexiusculi, ultimus ad peripheriam rotundatus vel indistincte angulatus; callus basalis, nitidus, albidus, circumscriptus ; apertura fere luñaris; perist. simplex, rectum, incrassatum; columella arcuata, simplex, cum perist. continua.

Diam. 7 , alt. $5 \frac{1}{2}$ mill.

The above, collected at the Tahitian Islands, was confounded by M. Hombron with a species inhabiting the Hawaiian Islands described by Dr. Philippi.

Helicina guppyi, Pse.

Helicina humilis (Guppy, non Hombr.), Ann. Nat. Hist. ser. 4, vol. i. p. 434 (1868).

To prevent confusion I alter the name of the above West-Indian species, which was preoccupied for one inhabiting Polynesia.

Helicina colorata, Pse.

Helicina colorata, Pse. Am. Journ. Conch. 1868, p. 156.

Helicina anaaensis, Mouss. Journ. de Conch. 1869, p. 66.

The above is the only species inhabiting the island of Annaa, where it was collected by Mr. Garrett. The above name was given to it by reason of the many variations of colour it passes through. It is wholly whitish, or of different shades of yellow or red, sometimes banded with the same colours; occasionally the last whorl is yellow, and the spire bright crimson.

\section{Helicina flavescens, Pse.}

Helicina flavescens, Pse. Am. Journ. Conch. 1867, p. 228.

Helicina pacifica, Pse. Am. Journ. Conch. 1865, p. 291.

The redescription of the above species by myself arose from omitting to name the specimens in my collection when first described. I retain the above name as being more appropriate and its description more full.

\section{Genus Taheitia.}

Taheitia, H. \& A. Ad. Ann. Nat. Hist. 1863, p. 19.

The chief and, I may add, the only peculiarity which serves to distinguish the above genus from Truncatella is its operculum. The other characters mentioned by Messrs. Adams, viz. the porrection of the last whorl and its being disconnected from the penultimate whorls, are not constant.

Taheitia aurantia, Gld., can scarcely be distinguished from Truncatella pacifica, Pse., in any of its characters except the operculum. Taheitia pallida, Pse., is also in all respects a Truncatella except the operculum.

The East-Indian species wallacei, H. Ad., and clathrata, H. Ad. \& Ang., are more characteristic of this genus than the Polyne- 
sian, excepting the type $T$. porrecta, Gld. I am of opinion, however, that several species described as Truncatella will prove to belong to the above genus when the operculum is examined.

Taheitia scalariformis, Rve.

Truncatella scalariformis, Rve. Proc. Zool. Soc. 1842, p. 197.

Truncatella arcticostata, Mouss. Journ. de Conch. 1869, p. 68.

The above was first collected by the late Mr. Cuming at the island of Annaa, and since by Mr. Garrett. It is common about the roots of the cocoa-nut trees, and is the only species of its genus inhabiting the above locality.

Truncatella concinna, Pse.

T. imperforata, cylindracea, elongata, tenuiuscula, nitida, alba, straminea vel rufo-cornea, confertim et recte costulata, costis in anfr. ultimo circa 31 ; anfr. superst. 4, plano-convexi, ultimus ad basin cristo-costatus; apertura subobliqua, ovalis, postice vix angulata; perist. simplex, continuum, subincrassatum, album, adnatum.

Long. 7, diam. $2 \frac{1}{2}$ mill.

Hab. Insula Apaiang (Kingsmill).

The species nearest allied to the above with which I am acquainted is $T$. scalariformis, Rve.

Truncatella costellifera, Pse.

T. crassa, non rimata, elongata, turrito-cylindracea, parum nitens, rubello-favescens, longitudinaliter costata, costis rectis, compressis, in anfr. ultimo circa 20 ; anfr. persistentes 5 , convexi, ultimus circa basin compresso-costatus; apertura vix obliqua, ovalis; perist. simplex, continuum, adnatum; labrum dextrum acutum, intus vix incrassatum, extus prope marginem fortiter costatum, costa compressa, prominens, circa basin extensa, cum costa umbilicali continua.

Long. 7, diam. $2 \frac{1}{2}$ mill.

Hab. Insula Vavau (Brazier).

The chief peculiarity of the above species is the stout rib encircling the outer lip, which continues around the base, connecting with the usual umbilical rib, of even size throughout; there is no trace of an umbilical fissure. It was collected at the above locality by Mr. John Brazier.

\section{Genus Plecotrema, H. \& A. Ad.}

Two species of the above genus inhabit the Hawaiian Islands, viz. P. striata, Phil., and P. clausa, H. \& A. Ad.

Dr. Philippi had probably both species before him when his description was drawn up ; that by Dr. Pfeiffer of the same species (Mon. Auric. 1856, p. 104) is more accurate. The description of $P$. clausa by Messrs. Adams agrees more strictly with the form I adopt as the type of that species than the one subsequently published by Dr. Pfeiffer in 'Novit. Conch.' vol. i. p. 15. 
As the two species have been confounded by many collectors, I furnish a detailed description of each, drawn up from mature specimens, of which I have had an opportunity of examining a large number.

\section{Plecotrema striata, Phil.}

Auricula striata, Phil. Zeit. f. Mal. 1846, p. 98.

Plecotrema striata, Pfr. Mon. Auric. 1856, p. 104.

T. crassa, imperforata, globoso-conica, subovata, nigra, spiraliter impresse striata, striis rare incequaliter distantibus, interstitiis planis, striis remote hispidulis; spira conica, mucronata, convexiuscula; sutura linearis; anfr. 7 , ultimus tumidiusculus, $\frac{1}{2}$ longitudinis testa fere aquans, basi vix attenuatus; apertura fere verticalis, oblonga, postice acuta, vix contracta, basi rotundata, nigricans vel cinereo-nigrescens ; plica parietales 2, lamelliformes, superior perobliqua, altera extus bifida, valde compressa, elevata, profunde intrans; plica columellaris valida, transversa; peristoma rectum, acutum, marginibus plerumque callo lato tenuissimo junctis, dextro intus, dimidio anteriore et circa basin prope marginem calloso, bidentato; columella extus ad marginem vix elevato-laminata, infra juxta regionem umbilicalem vix crispata.

Dimens. $8 \times 5$, vel $5 \times 3$ mill.

$H a b$. Insula Oahu.

This species is constant in its characters, and distinct from all varieties of $\boldsymbol{P}$. clausa, H. \& A. Ad.; the shell is black, solid, engraved concentrically with impressed striæ, which are generally regular; but occasionally one is omitted, leaving the interspaces wider; the interstices are flat; the last whorl is swollen, about one half the length of the shell; the aperture is very slightly oblique, acute posteriorly, more so than in P. clausa, and in some specimens constricted, caused by a depression around the upper part of the last whorl near the suture; the lamellæ on the inner lip are oblique, more compressed and prominent than in $P$. clausa, the lower one especially, which passes round far within the aperture; the outer lip on its edge is acute, on its anterior half and around the base, just within the margin, it is slightly callous, on which part the teeth are placed, which are smaller than those in $P$. clausa. The columella is bordered by an elevated lamina; the aperture is blackish or dark cinereous; the teeth and lamellæ white; the striæ are furnished with remote bristly hairs. The characters by which the above may be readily distinguished from $P$. clausa are its black colour, larger size, dark aperture, not being ribbed or lirate but striate, the aperture being more open, the lamellæ on the wall of the aperture compressed and prominent, the teeth on outer lip smaller and the callosity not so thick. These characters are constant, even in specimens of the smallest size.

Plecotrema clausa, A. Ad.

T. imperforata, ovato-conoidea, crassa, vix nitidula, spiraliter costulata aut lirata, costis rotundatis, interstitiis setulis munitis et lon- 
gitudinaliter tenuiter striatis, pallide fulva vel rufescenti-fusca, rare indistincte fasciata; spira conica, apice acuto, vix mucronato; anfr. 7 , planiusculi, ultimus convexus, $\frac{1}{2}$ longitudinis testa fere aquans, basi vix attenuatus; apertura vix obliqua, oblonga, angusta, ringens, basi anguste rotundata, postice acute angulata; plica parietales 2, superior compressa, perobliqua, cum labro callo juncta, altera bifida; plica columellaris compressa, transversa; labrum dextrum extus incrassatum, intus ad marginem valde callosum, fortiter bidentatum; apertura pallida, albida.

Dimens. $5 \times 3$ vel $4 \times 2$ mill.

Hab. Insula Hawaii.

This species is rare; it is distinctly roundly ribbed, and the teeth of the aperture are very strongly developed. It varies considerably, the grooves becoming narrower and the interspaces taking a flattened lirate shape. The grooves and striæ of this and $P$. striata are furnished with remote hairy bristles, which fall off when they become dry, and are therefore seldom preserved on cabinet specimens. The largest specimens, lirate and of a reddish colour, are usually mistaken for $P$. striata, Phil. This species never attains to the size of $\boldsymbol{P}$. striata, and is never black.

The species inhabiting the Island of Bourbon and registered by M. Deshayes in his work on the Mollusca of that island as P. striata, Phil., with a doubt, agrees with the type of the above species. I find, on comparison, no characters to separate them.

Lamodonta conica, Pse.

Laimodonta conica, Pse. Proc. Zool. Soc. 1862, p. 242; Am. Journ. Conch. 1861, p. 101, pl. 12. f. 15.

Laimodonta anaaensis, Mouss. Journ. de Conch. 1869, p. 63, pl. 5. f. 1 .

The above was originally described from specimens collected in Central Polynesia. It was afterwards discovered by Mr. Garrett at the Island of Annaa, where it attains to a larger size. It varies in colour; but the other characters of the shell are identically the same in both localities.

\section{Melampus mucronatus, Gld.}

Melampus mucronatus, Gld. Proc. Bost. Soc. 1849; Rep. Am.Exp. Ex. 1852, p. 204, fig. 242.

Ellobium oryza, H. \& A. Ad. Proc. Zool. Soc. 1854, p. 8.

Auricula oryza, Pfr. Mon. Auric. 1856, p. 141 ; Novit. Conch. vol. i. p. 28 , pl. 7 . f. $17-19$.

I have received from Annaa fifty or more specimens of $M$. oryza, H. \& A. Ad., the only species of its type inhabiting that small atoll, and type specimens of $M$. mucronatus, Gld., from the collection of the American Exploring Expedition, found at Raraka, a short distance from Annaa.

The two are synonymous, although the descriptions vary. The Raraka specimens have more colour, and are rather smaller. The 
most cssential difference between the two descriptions is, that $\boldsymbol{M}$. oryza is described as having but three plaits on its outer lip, while M. mucronatus, Gld., has eight; the plaits decrease in size as they recede from the base, so that on many specimens the posterior ones are quite small or become obsolete; the mucronation is indistinct on most specimens, the basal striæ constant. I would add to the descriptions that the spire is very finely striate longitudinally, and the last whorl slightly depressed posteriorly, giving the spire a slender appearance. The species is certainly distinct, and not a variety of M. luteus, Quoy, as suggested by Dr. Gould. The latter species I have in all stages of growth from the same locality.

The following synonym was omitted above.

Atropis producta, Pse.

Realia producta, Pse. Proc. Zool. Soc. 1864, p. 673.

Hydrocea raiatensis, Mouss. Journ. de Conch. 1869, p. 67.

$H a b$. Insulæ Raiatea et Tahaa.

On comparison of a large number of specimens, the above will be found to vary considerably. The type is represented on the island of Bolabola by $A$. bolabolensis, Dohrn, and at Tahiti by A.terebralis, Gld. A. elongata, Pse., inhabiting Raiatea, is more distantly related to it.

\section{Catalogue of Genera and Species.}

The whole number of species of land-shells known as inhabiting Polynesia is 626 .

In the following Catalogue the Helicterina are omitted, a list having been lately published in the Society's 'Proceedings' (1869, p. 644), to which but one species has been added since.

The genera and number of species of each are as follows :-

\section{INOPERCULATA.}

Helicterina, 223.

Vitrina, Drap., 2.

Succinea, Drap., 26.

Truella, Pse., 3.

Catinella, Pse., 2.

Carelia, H. \& A. Ad., 6.

Chlorrea, Alb., 1.

Tornatellina, Beck, 18.

Lamellina, Pse., 2.

?Bulimus, Scop., 2.

Stenogyra, Shutt, 5 .

\section{Operculata.}

Diadema, Pse., 3 . Cyclophorus, Mont., 1. Ostodes, Gld., 5. Registoma, Hass., 1. Pupina, Vign., l.
Partula, Fér., 63.

Vertigo, Müll., 19.

Rhysota, Alb., 1.

Hyromia, Risso, 1.

Trochomorpha, Alb., 21.

Endodonta, Alb., 10.

Pitys, Beck, 33 .

Microcystis, Beck, 4.

Helicopsis, Beck, 30.

?Helix, Linn., 10.

Palaina, Semp., 15.

Moussonia, Semp., 1 .

Cyclostomus, Mont., 1.

Omphalotropis, Pfr., 16.

Atropis, Pse., 18. 


\section{$2 \mathrm{BHL}$ Biodiversity Heritage Library}

Tweeddale, Arthur

Hay,

I

. 1871. "May 2, 1871." Proceedings of the Zoological Society of London 1871, 325-477. https://doi.org/10.1111/j.1469-7998.1871.tb00478.x.

View This Item Online: https://www.biodiversitylibrary.org/item/90542

DOI: https://doi.org/10.1111/j.1469-7998.1871.tb00478.x

Permalink: https://www.biodiversitylibrary.org/partpdf/73742

\section{Holding Institution}

Natural History Museum Library, London

\section{Sponsored by}

Natural History Museum Library, London

\section{Copyright \& Reuse}

Copyright Status: Public domain. The BHL considers that this work is no longer under copyright protection.

This document was created from content at the Biodiversity Heritage Library, the world's largest open access digital library for biodiversity literature and archives. Visit BHL at https://www.biodiversitylibrary.org. 